\title{
Foraminifera from the
}

Northern Olympic

Peninsula, Washington

U.S GEOLOGICAL SURVEY, PROFESSIONAL PAPER 374-G

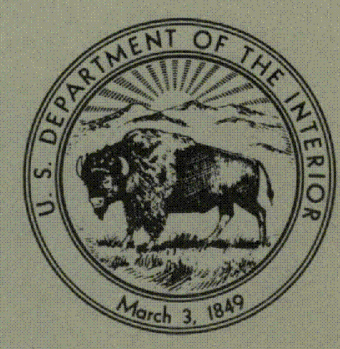





\section{Foraminifera from the}

\section{Northern Olympic}

Peninsula, Washington

By WELDON W. RAU

SHORTER CONTRIBUTIONS TO GENERAL GEOLOGY

GEOLOGICAL SURVEY PROFESSIONAL PAPER $374-\mathrm{G}$

Stratigraphic and paleoecologic

significance of Foraminifera from

a Tertiary sequence
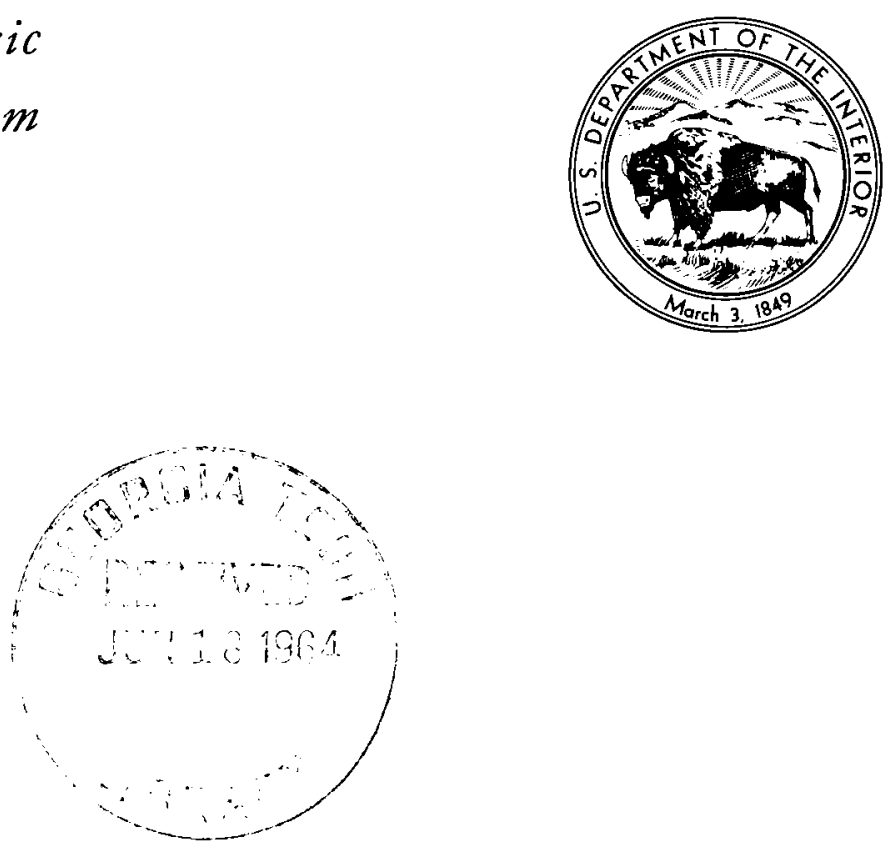

UNITED STATES GOVERNMENT PRINTING OFFICE, WASHINGTON : 1964 
UNITED STATES DEPARTMENT OF THE INTERIOR

STEWART L. UDALL, Secretary

GEOLOGICAL SURVEY

Thomas B. Nolan, Director

For sale by the Superintendent of Documents, U.S. Government Printing Office

Washington, D.C., 20402 


\section{CONTENTS}

Abstract

Introduction and acknowledgments . . . . . . . . . . .

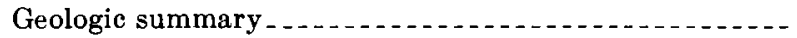

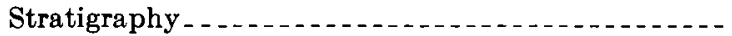

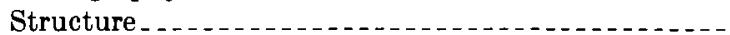

Foraminifera from the Crescent formation . . . . . . . . . .

Planktonic assemblages........................

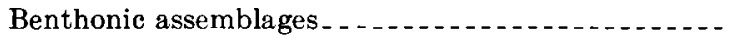

Age and correlation

Foraminifera from the Aldwell formation . . . . . . . .

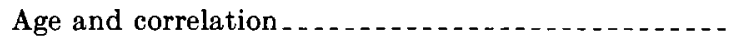

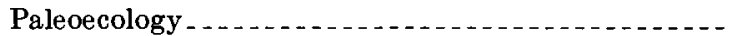

Foraminifera from the Twin River formation

Age and correlation

Lyre River section .........................

Deep Creek section ..........

Coast section.

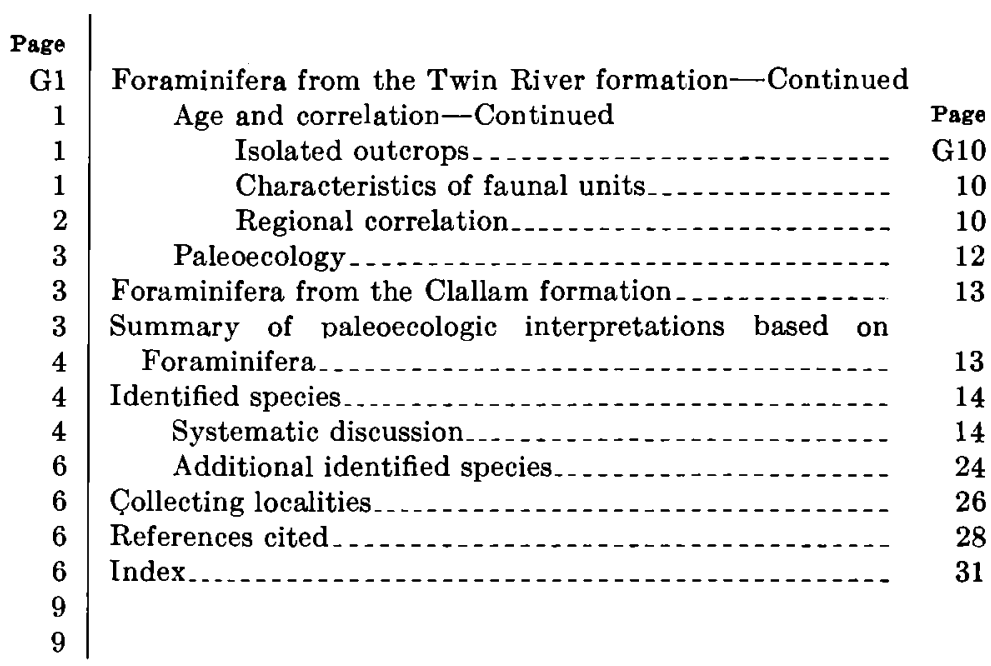

\section{ILLUSTRATIONS}

[Plates 1-4 in pocket; others follow index]

Plate 1. Geologic map showing U.S. Geological Survey collection localities.

2. Foraminifera from a part of the Twin River formation on Lyre River.

3. Foraminifera from a part of the Twin River formation on Deep Creek.

4. Foraminifera from a part of the Twin River formation between the mouths of East Twin River and Murdock Creek.
Plates 5-7. Foraminifera from the northern. Olympic Peninsula, Washington.

FIgURE 1. Stratigraphy of this report, southwest Washington, and a Pacific Coast standard......

2. Frequency of occurrence of species in Twin River formation

\section{TABLES}

Table 1. Benthonic Foraminifera from the Crescent formation

2. Foraminifera from the Aldwell formation. . . -

3. Foraminifera from isolated localities in the Twin River formation.

\begin{tabular}{r|} 
Page \\
G3 \\
4 \\
7
\end{tabular}

Page

TABLE 4. Foraminifera from the Clallam formation $\ldots$ G13

5. Additional identified species.... 25

6. Collecting localities........ 26 



\title{
SHORTER CONTRIBUTIONS TO GENERAL GEOLOGY
}

\section{FORAMINIFERA FROM THE NORTHERN OLYMPIC PENINSULA, WASHINGTON}

\author{
By Weudon W. RaU
}

\begin{abstract}
Foraminifera from a Tertiary sequence that crops out on the northern part of the Olympic Peninsula, Wash., show stratigraphic and ecologic significance. Forty-two species that are important both to correlations and to ecologic interpretations are illustrated and systematically discussed. The Foraminifera indicate that some of the rocks may be as old as early Eocene. The oldest rocks are tentatively referred to the Penutian stage of Mallory. Other parts of the sequence are referred to the Ulatisian and Narizian stages of Mallory, the Refugian stage of Schenck and Kleinpell, and the Zemorrian and Saucesian stages of Kleinpell.

Several short periods of shallow, sheltered sea conditions are suggested by the Foraminifera from several parts of the stratigraphic sequence, but Foraminifera from most of the rocks suggest relatively deep, open-sea conditions. With the exception of shallow, warm-water conditions in rocks of probable middle Eocene age, the Foraminifera suggest that cool-to-cold water temperatures, regardless of depth, prevailed during the deposition of most of the rocks of Tertiary age in the northern Olympic Peninsula.
\end{abstract}

\section{INTRODUCTION AND ACKNOWLEDGMENTS}

This report deals with the stratigraphic and ecologic significance of Foraminifera contained in a Tertiary sequence that crops out in the northern part of the Olympic Peninsula, Wash. (pl. 1). The work was done as a part of a program of geologic investigations for oil and gas possibilities conducted by the U.S. Geological Survey. The geology of four 15 -minute quadrangles, the Pysht, Lake Crescent, Joyce, and Port Angeles, was mapped and the results published as two separate reports (Gower, 1960; Brown and others, 1960). Samples for foraminiferal study were collected during the course of the geologic fieldwork in the summer months from 1952 to 1956 . Stratigraphic sections were measured by plane table and telescopic alidade.

Foraminifera indicative of Eocene, Oligocene, and Miocene age were recognized in the northern Olympic Peninsula. Assemblages compare with previously known faunas from other parts of the west coast and are referred to the Penutian, Ulatisan and marizian stages of Mallory (1959), the Refugian stage of Schenck and Kleinpell (1936), and the Zemorrian and Saucesian stages of Kleinpell (1938).

Detailed studies of the Foraminifera are hampered by their scarcity and poor preservation. Foraminifera are particularly rare in the older part of the sequence but they generally become more plentiful and are better preserved in the younger strata. Many hundreds of samples were taken, but assemblages that are significant of age and environment were obtained from 183 localities.

Several methods of disaggregating the samples were tried, but the kerosene-water method was the most successful. When possible, approximately 150 grams of each sample was washed and all residue that was retained on a 150-mesh screen was examined.

Many members of the U.S. Geological Survey gave assistance on the report. R. D. Brown, Jr., H. D. Gower, and P. D. Snavely, Jr., collected many of the samples, measured some of the sections, and supplied the geologic data upon which parts of this report are based. All photographs of Foraminifera accompanying the report were retouched by Mrs. Mary Wagner.

\section{GEOLOGIC SUMMARY STRATIGRAPHY}

The Soleduck formation of Reagan (1909) is stratigraphically the lowest unit known to crop out in the area and consists primarily of argillite and graywacke with minor amounts of conglomerate, arkosic sandstone, and reddish calcareous argillite in association with volcanic rocks. Within the mapped area, the formation crops out only in the area south of a line extending generally east and west of the south shore of 
Lake Crescent (pl. 1). The thickness of the formation is unknown, but in the mapped area it is estimated to be about 16,000 feet. However, these rocks are believed to overlie similar rocks to the south, and the formation may therefore be much thicker. Although stratigraphically diagnostic fossils have not been found in the formation, its age is tentatively assigned as early Eocene (Brown and others, 1960). No Foraminifera from this formation were studied in connection with the present report.

In some places the Crescent formation conformably overlies, and in other places it interfingers with, Reagan's Soleduck formation. It consists primarily of pillow basalt, flow breccia, amygdaloidal basalt, and waterlaid tuff with minor amounts of tuffaceous sedimentary rocks and reddish calcareous argillite. In the area mapped by Gower (1960) and by Brown and others (1960) the formation is exposed chiefly in a belt that extends from Round Mountain on the east to Deadmans Hill on the west. It is also exposed on the north flank of the Clallam syncline between the mouth of Whiskey Creek and the Elwhat River.

The formation varies considerably in thickness and generally becomes thinner to the west; its greatest thickness in the southeastern part of the mapped area is estimated to be 25,000 feet, and the thinnest section, which is in the extreme western part near Bear Creek, is estimated to be 6,500 feet thick. Foraminifera from 11 localities indicate that the Crescent formation is post-Cretaceous in age and may be, in part at least, as young as middle Eocene.

The Aldwell formation conformably overlies and interfingers with the Crescent formation. It consists mainly of well-indurated marine siltstone with lesser amounts of standstone and volcanic rocks. Discontinuous outcrops of this unit are present south of the Clallam syncline and extend from east to west across the area (pl. 1). The Aldwell formation has a maximum thickness of about 3,000 feet in the vicinity of Lake Aldwell, but it is thinner elsewhere and in some places it is overlapped by younger rocks. The age assignment of the formation is based largely on Foraminifera, and they suggest an early late Eocene age.

The Lyre formation as redefined by Brown and others (1956) conformably overlies the Aldwell formation and consists chiefly of conglomerate and sandstone. It crops out in the central part of the mapped area in a belt that extends from about a mile east of the Elwha River to beyond the west border of the mapped area. The thickness varies from more than 3,000 feet in the East Twin River area to only a few feet in some places; in other parts of the area the formation is entirely absent. Al- though no Foraminifera were obtained from the Lyre formation, assemblages of late Eocene age were collected from the rocks that crop out immediately above and below the formation.

The Twin River formation, as redefined (Brown and Gower, 1958) overlies the Lyre formation and older rocks. Its outcrop belt occupies approximately the northern half of the mapped area and extends beyond both the east and west boundaries. The Twin River formation is divided into a lower, a middle, and an upper member. The lower member is chiefly thinbedded siltstone and sandstone and has a maximum thickness of 7,500 feet and an average thickness of about 2,000 feet. The middle member is primarily massive to thin-bedded siltstone and contains abundant concretions. In places it is estimated to be as much as 5,000 feet thick, and it has an average thickness of about 2,000 feet. The upper member is predominantly massive, semi-indurated mudstone and sandy siltstone but includes some beds of calcareous sandstone. Its thickness is about 3,500 feet in the western part of the area, where its upper contact with the Clallam formation is exposed. Foraminifera from the Twin River formation range in age from late Eocene to late Oligocene or early Miocene.

The Clallam formation is the youngest known Tertiary unit in the area. It generally crops out only in the area north of Last Creek and west of Pillar Point. The formation is composed primarily of poorly sorted gray fine- to medium-grained thick-bedded sandstone with minor amounts of conglomerate and sandy siltstone. It is estimated to be more than 2,500 feet thick. A Miocene age has been assigned to the Clallam formation, on the bases of both the mollusks and Foraminifera.

\section{STRUCTURE}

The principal structural feature of the area is the Clallam syncline. Its axis has been mapped from a point near the mouth of Murdock Creek eastward to the east boundary of the area. It is a west-trending asymmetric fold with steeper dips along its south limb. Smaller east-plunging folds are also present, particularly in the eastern part of the area. The Soleduck formation of Reagon is intensely deformed but no large continuous folds have been traced. Most of the major faults are parallel to the fold axes and trend generally westward. Some of them show stratigraphic displacements of as much as 5,000 feet. A few north-trending faults are also present, particularly in the eastern part of the area. No major faulting is believed to affect the measured sections; therefore, faults are not shown on plate 1. 


\section{FORAMINIFERA FROM THE CRESCENT FORMATION}

Two distinctly different types of foraminiferal faunas were found in the Crescent formation. One of these consists almost entirely of planktonic Foraminifera and is known only from lenticular bodies of reddish argillaceous limestone interbedded with volcanic rocks. The other type of fauna consists chiefly of benthonic Foraminifera, and is known to occur only in basaltic sandstone and tuffaceous siltstone in the upper part of the Crescent formation.

\section{PLANKTONIC ASSEMBLAGES}

Foraminifera were first reported from the lenticular bodies of reddish argillaceous limestone of the Crescent formation by Pardee (1921, p. 232) and were later mentioned by Park (1946, p. 310). About 50 thin sections of reddish argillaceous limestone from 12 localities were examined in connection with the present study. Five of these localities, f11711 to f11715 (pl. 1), are within the mapped area. Because the fossils could not be separated from the matrix, they were examined only in thin section and were not specifically identified. Most of the Foraminifera are planktonic and are either globigerinids or globorotalids, but none are globotruncanids (pl. 7, figs. 12, 13). The Foraminifera are abundant locally and are commonly concentrated in thin layers. Such concentrations of planktonic Foraminifera as are found in the calcareous rocks of the Crescent formation are rarely found in other Tertiary rocks of the Pacific Northwest.

The abundance of planktonic foraminiferal remains and the lack of benthonic foraminiferal remains in these red argillaceous limestone beds could be indirectly attributed to contemporaneous volcanic activity. The small lenticular bodies of red limestone probably represent periods during which volcanism was locally inactive. Nevertheless volcanism probably continued in nearby areas because volcanic debris is incorporated in the red limestone. It is unlikely that any type of Foraminifera can live in or near areas that are undergoing submarine volcanism. Planktonic Foraminifera can be brought into such an environment by ocean currents, but they probably would die in mass and their tests would be deposited in concentrations as part of the accumulating sediments. Benthonic or nonfloating forms are less likely to be transported in large numbers by ocean currents and therefore in general only planktonic foraminiferal tests would be deposited.

The planktonic assemblages of the Crescent formation are probably post-Cretaceous in age because they consist of globigerinids and globorotalids without any globotruncanids, which are indicative of a Cretaceous age.

\section{BENTHONIC ASSEMBLAGES}

In addition to the planktonic fauna, 25 species of benthonic Foraminifera were collected from six other localities, f11716 to f11721, in basaltic sandstone and tuffaceous siltstone of the upper part of the Crescent formation (table 1). Although locality f11721 was mapped as Twin River formation by Brown and others (1960), the foraminiferal fauna from there is typical of the Crescent formation; it is therefore regarded here as fauna of the Crescent formation. Locality f11720 at Observatory Point yielded the most complete assemblage. Berthiaume (1938) described several species of orbitoid Foraminifera from this locality. Samples collected during the present study also contain a few orbitoid Foraminifera, but Amphistegina californica Cushman and M. A. Hanna is the most common form in these collections.

TABLE 1.-Benthonic Foraminifera from the Crescent formation [X, abundant to common; /, few to rare; ?, questionably identifled]

Species
(arranged taxonomically)

The association of orbitoid Foraminifera with many Amphistegina suggests a marine environment with warm, shallow water. Vaughan $(1945$, p. 69,70$)$ stated :

The Discocyclinidae are warm-, shallow-water organisms. * * * The best temperature conditions Ifor the Discocyclinidae] would be those between $25^{\circ}$ and $31^{\circ} \mathrm{C}$. The depth of water in which the Discocyclinidae lived ranged from near or slightly below tide level to perhaps 100 meters. Some forms probably lived in tide pools.

Cushman (1950, p. 300, 301) stated:

This family [Amphistegenidae] is largely limited to the Tertiary and Recent oceans. Asterigerina is often abundant on coral reefs and in warm shallow waters of the West Indian region, but less abundant elsewhere. Amphistegina is very abundant in similar conditions and often is present in enormous 
numbers in shoal water, particularly of the Indo-Pacific. It is frequent in such conditions through the late Tertiary. It is very probable that the genus is limited to about 30 fathoms in its living condition as, like other large Foraminifera, it seems to have commensal algae, the limits of which on account of the penetration of sunlight in the ocean are limited to this same depth.

\section{AGE AND CORRELATION}

On the basis of orbitoid Foraminifera, Berthiaume (1938) correlated the Crescent formation exposed at Observatory Point with the orbitoid-bearing Sierra Blanca limestone of Santa Barbara County, Calif., and referred them both to an early middle Eocene age. Mallory (1953) agreed with this correlation, but also suggested a correlation of the Crescent formation with the "Mabury Reef sandstone" and "basal Spiroglyphus sands" at Media Agua Creek in California. He assigned all these units to his Penutian stage, which he regarded as early Eocene (Capay) in age (Mallory, 1959).

The fauna here described from the Crescent formation substantiates a general age assignment of early to early middle Eocene. However, in terms of Mallory's stages the present fauna suggests a Ulatisian age rather than a Penutian age because of the common occurrence of Amphistegina californica. This species was recorded by Mallory only from his Ulatisian stage (1959, p. 84), which he regarded as middle Eocene and possibly early Eocene in part (Mallory, 1959, p. 77).

In addition to the previously suggested correlations the fauna of the Crescent formation may also be correlated with that described from rocks of Eocene age at Cape Blanco, Oreg. (Bandy, 1944). Practically all the species in the Crescent fauna are represented by closely related forms in the Cape Blanco fauna and five species are regarded as identical.

\section{FORAMINIFERA FROM THE ALDWELL FORMATION}

Foraminifera are not abundant in the Aldwell formation, but 49 species from nine localities in different parts of the formation were identified (table 2).

\section{AGE AND CORRELATION}

The foraminiferal fauna of the Aldwell formation can best be correlated with Laiming's A-2 zone of the Eocene of California (1940; see also fig. 1, this report). Approximately one-third of the species known from the Aldwell formation (table 2) were recorded by Laiming from his A-2 zone, and many others in the Aldwell formation are either comparable with or similar to species of his A-2 zone. Uvigerina churchi Cushman and Siegfus, $U$.garzaensis Cushman and Siegfus, Bulimina corrugata Cushman and Siegfus, and B. lirata Cush-
TABLE 2.-Foraminifera from the Aldwell formation

[X, abundant to common; /, few to rare; ?, questionably identifled]

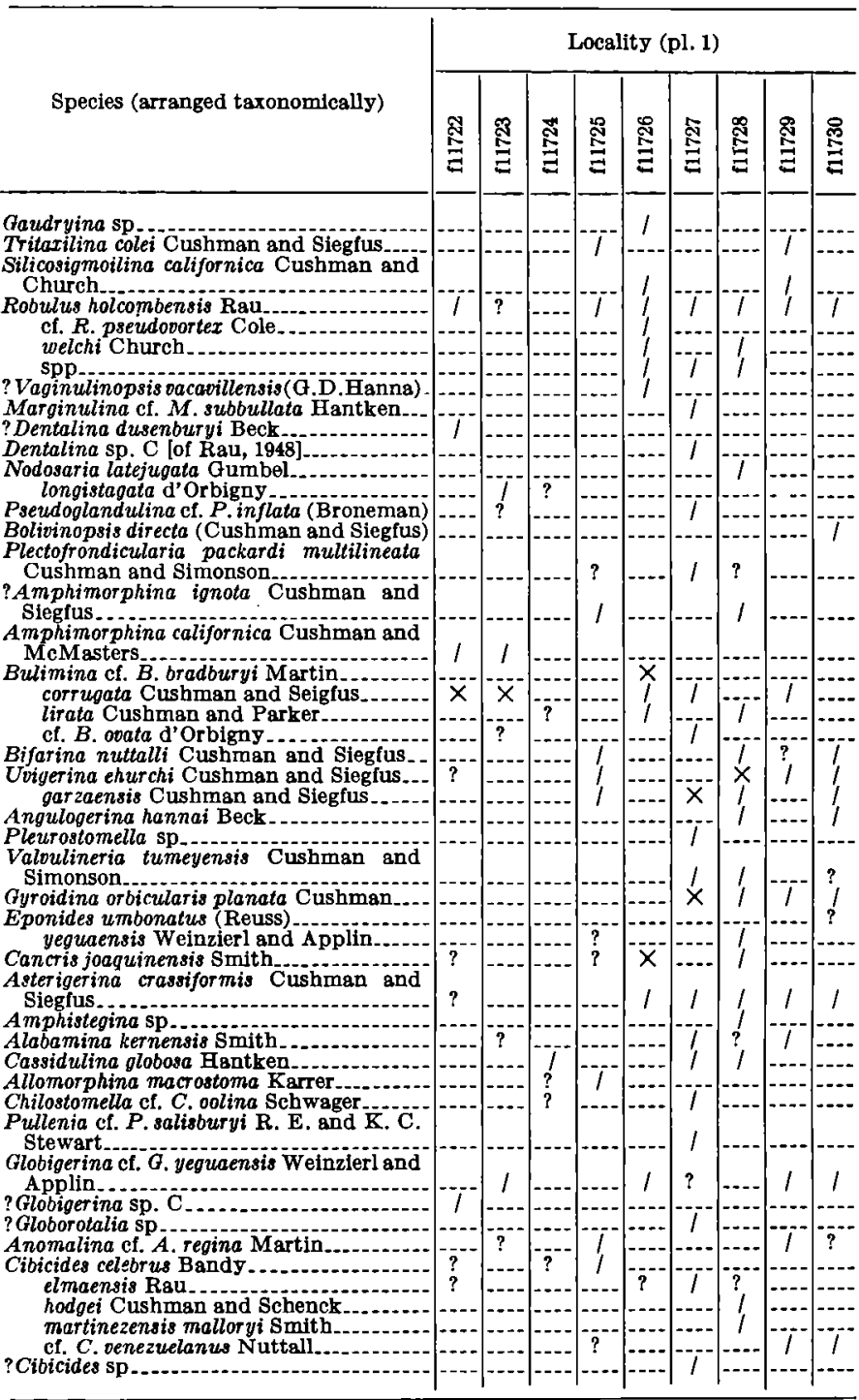

man and Parker, all of which are in the Aldwell, are regarded as characteristic of the A-2 zone. A low position in the A-2 zone is suggested for the Aldwell fauna because it contains such species from Laiming's $\mathrm{C}$ zone as Asterigerina crassiformis Cushman and Siegfus, Bifarina nuttalli Cushman and Siegfus, Bolivinopsis directa (Cushman and Siegfus), and Tritaxilina colei Cushman and Siegfus. Laiming (1940) showed that these species, which are common in his $\mathrm{C}$ zone, also occur in the lower part of his A-2 zone. The fauna of the Aldwell formation is correlated with the $\mathrm{A}-2$ rather than C-zone faunas because it contains only about one-half as many species that are known from the $\mathrm{C}$ zone as are known from the A-2 zone or higher. This correlation is supported also by stratigraphic evidence because Bzone assemblages which normally separates C-zone and 
A-zone assemblages have not been found in the relatively complete section above the Aldwell formation.

Of the faunas noted in Mallory's division of rocks of Eocene age in the California Coast Ranges (1959), the fauna of the Aldwell formation is best compared with that of his Bulimina corrugata zone of the lower part of his Narizian stage. The Aldwell formation contains
Amphimorphina californica Cushman and McMasters, a form that Mallory indicated is restricted to the upper part of his subjacent Ulatisian stage in California. Therefore a part of the Ulatisian stage may be represented in the Aldwell formation. However, A. californica is found frequently in western Washington and Oregon in association with Foraminifera that compare

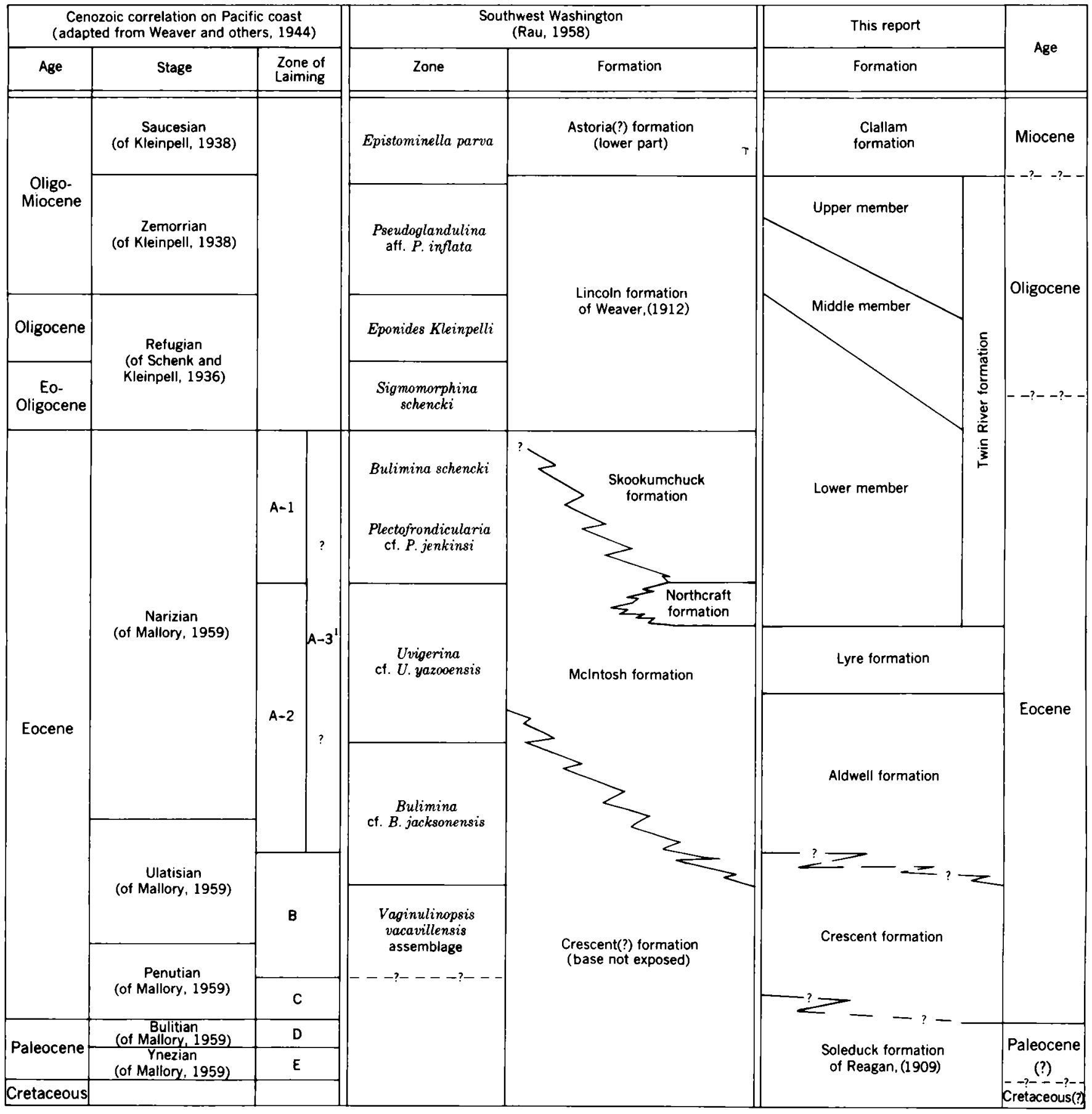

1 Position of A-3 zone modified by Rau (1958)

2 B zones not differentiated

Fiodre 1.-A comparison of the stratigraphy of this report with that of southwest Washington and a standard of the Pacific Coast. $6788330-63-2$ 
best with those of Mallory's $B$. corrugata zone and therefore, locally at least, $A$. californica may not be necessarily indicative of a pre-Narizian age. Faunas resembling those in the Aldwell formation are also found in the Canoas siltstone member of the Kreyenhagen shale (Cushman and Siegfus, 1942) and in the Alhambra formation (Smith, 1957) of California; similar faunas have also been found by the writer in the upper part of the Yamhill formation and the lower parts of the Nestucca and Toledo formations in Oregon, and in the McIntosh formation of Washington.

\section{PALEOECOLOGY}

The similarity of all known assemblages of the Aldwell formation suggests that they probably lived in similar ecological conditions, but conclusions regarding these conditions are necessarily based on considerable supposition. It is possible to be reasonably certain of only a very generalized concept of the environment in which the Foraminifera of the Aldwell formation lived.

Bandy's work (1953) with Recent Foraminifera from three widely spaced profiles normal to the California coast, off San Diego, Point Arguello, and San Francisco, is the only record of west coast assemblages that are at all similar to the fauna of the Aldwell formation. These assemblages are confined to the deepest and coldest water that was sampled, and are largely from the Point Arguello profile. Several of the species in these Recent assemblages are similar to species of the Aldwell formation and most of the genera are represented in the fauna of the Aldwell formation. The comparable forms from off the California coast are recorded chiefly from depths between 3,000 feet and 12,000 feet and at temperatures between $15^{\circ} \mathrm{C}$ and $0^{\circ} \mathrm{C}$. The number of individuals with similarities to the Foraminifera of the Aldwell formation generally decreases in shallower and warmer water.

From these generalized comparisons with Bandy's work on Recent Foraminifera it can only be concluded that some of the Foraminifera in the Aldwell formation probably would have thrived in an environment of relatively deep and cold water.

\section{FORAMINIFERA FROM THE TWIN RIVER FORMATION}

Foraminifera are more common in the Twin River formation than in any other formation in the mapped area. Assemblages were found in nearly 400 samples and, of these, approximately 160 samples contained sufficient foraminiferal material to be useful in this study. Foraminifera were collected from three measured sections, the Lyre River (pl. 2), Deep Creek (pl. 3), and on the coast between the mouths of the East
Twin River and Murdock Creek (pl.4). Many samples were also obtained from isolated outcrops and short sections throughout the mapped extent of the Twin River formation (table 3 ).

Most samples contain only a few species of Foraminifera and are only sparsely fossiliferous, but because many samples were studied, a sizeable number of species were identified from the formation. Because they are poorly preserved, many of the Foraminifera are tentatively or questionably identified.

\section{AGE AND CORRELATION}

Precise correlations and age determination of foraminiferal assemblages in the Twin River formation are hampered by the scarcity and poor preservation of Foraminifera. Furthermore, some species that are known to have different stratigraphic ranges in other areas are found together in parts of the Twin River formation. This apparently anomalous association of species may be due to varied local ecology or perhaps to a reworking of fossils from lower parts of the section; therefore, age determinations of assemblages from isolated outcrops and correlations of faunas from parts of measured sections are based on assemblages or groups of assemblages rather than on individual species.

Four faunal divisions are recognized and they are referred to the upper Eocene upper Narizian stage (Mallory, 1959), the Eocene and Oligocene Refugian stage (Schenck and Kleinpell, 1936), and a lower part and an upper part of the Zemorrian stage (Kleinpell, 1938) of Oligocene or Miocene age.

Foraminifera were collected from all three members of the formation in a measured section in the Lyre River area (pl. 2) ; this section is used as the basic reference for the study of the foraminiferal sequence in the Twin River formation.

\section{LYRE RIVER SECTION}

Foraminifera are scarce in the lower member of the Twin River formation in the Lyre River section. Those species which are present, however, suggest a late Eocene age and for the most part they are recorded from the upper part of the Narizian stage of Mallory (1959). Angulogerina hannai Beck, Cassidulina globosa Hantken, and Globigerina cf. G. yeguaensis Weinzierl and Applin are the most significant species because they are most commonly known from rocks of late Eocene age in other areas.

No Foraminifera were obtained from approximately 1,400 feet of sandy strata in the upper part of the lower member, and the age of the upper part of the lower member could not be determined. Foraminifera indicative of the Refugian stage make their lowest occurrence in the Lyre River section at the base of the middle 


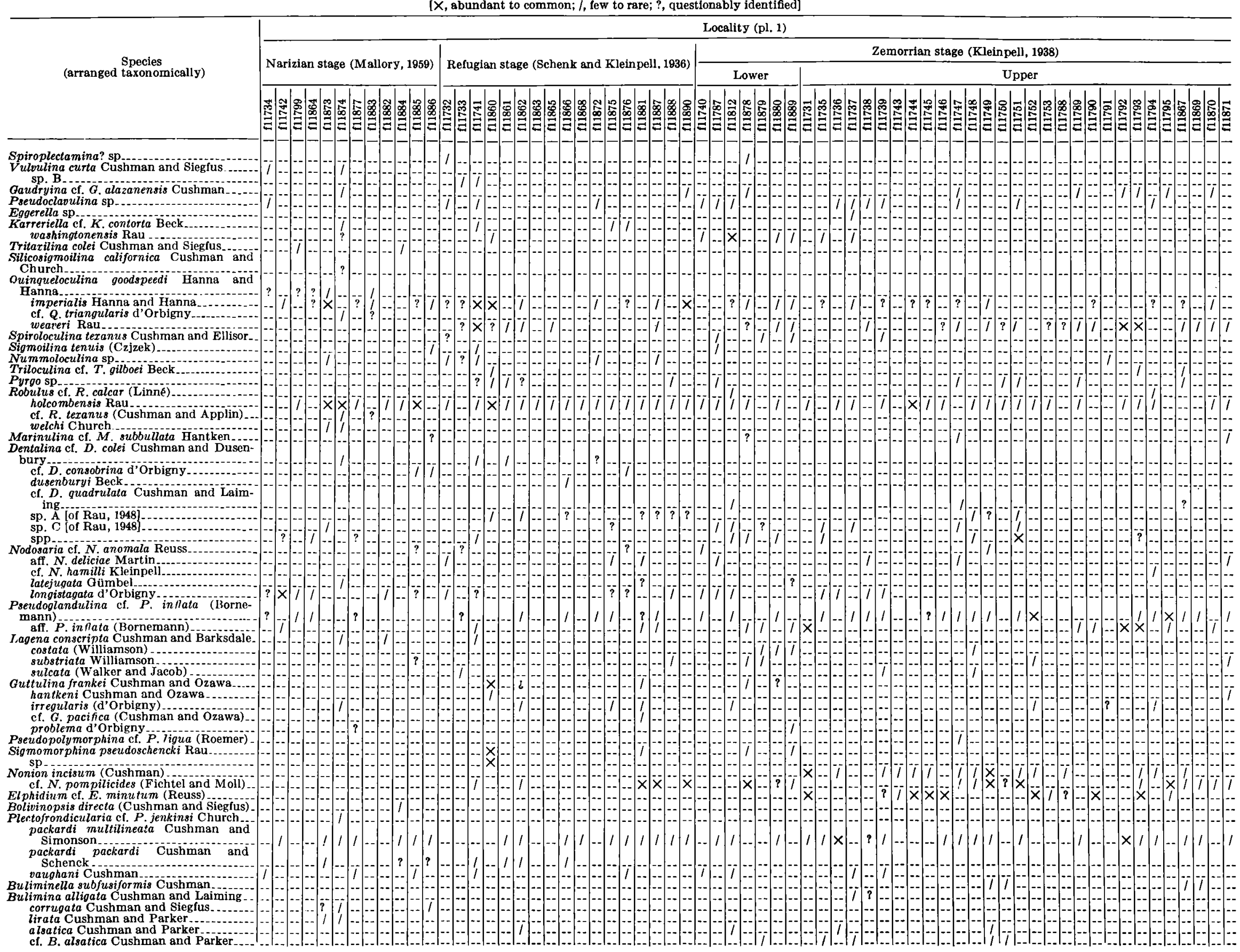


Species
(arranged taxonomically)

Narizian stage (Mallory, 1959)

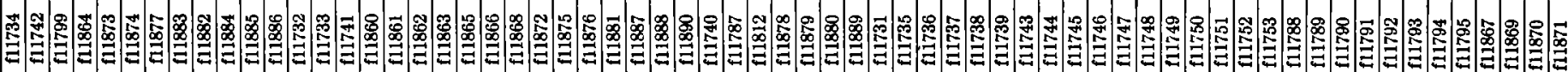

Bulimina alligata Cushman and Laiming Continued $B$ ovata d'Orbigny

schencki Beck -...-....................... sculptilus laciniata Cushman and Parker
Entosolenia sp
Bathing

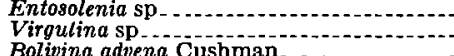

cf. $B$. jacksonensis Cushman and $\mathrm{Ap}$

marginata adelaidana Cushman and Cvigerinella obesa impolita Cushman and

Vigerinella obesa impolita Cushman a
Laiming .
Uvigerina churchi Cushman and Siegfus

cocoaensis Cushman

gallowayi Cushman ...............

garzaensis Cushman and Siegfu
Siphonodosaria ef. $S$. frizzelli Raul

Angulogerina hannai Beck

man)

Discorbis cf. D. humilis LeCalvez
Valvulineria aff. V. jacksonensis persimilis

menloensis $\mathrm{Rau}$-..

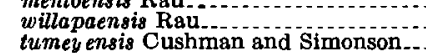

tumey ensis Cushman and Simonson-
Gyroidina condoni (Cushman and Schenck)

Gyroidina condoni (Cushman and Schenck)
orbicularis planate Cushman.........
Eponides duprei ciervoensis Cushman and

Simonson

mansfieldi oregonensis Cushman and R. E. and K. C. Stewart.......

umbonatus (Reuss)
yeguaensis Weinzieri and Applin-.-.

Epistomina eacenica (Cushman and Hanna)
Cancris joaquinensis Smith...............................

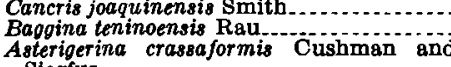

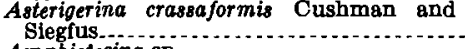

Aeratobulimina washburni Cushman and Alabamina kernensis Smith
Cassidulina crassipunctata Cushman and Hobson-
globosa Hantken--
sublobosa Brady.

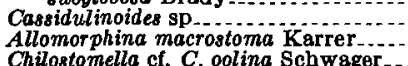

Pullenia bulloides (d'Orbigny)
of. $P$. salisburyi $R$. E. and K. C. Stewart Sphaeroidina pariabilis Reuss

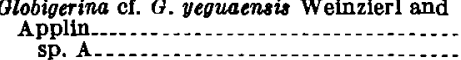

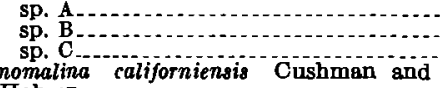

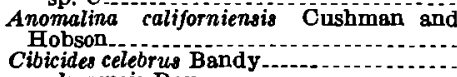

Cibicides celebrus Bandy
elmensis Rau
haydoni (Cushman and Schenck)

hodgei Cushman and Schenck
lobatus (d'Orbigny)

martinezensis malloryi $\mathrm{S}$ mith
cf. $C$. venezuelanus Nuttall

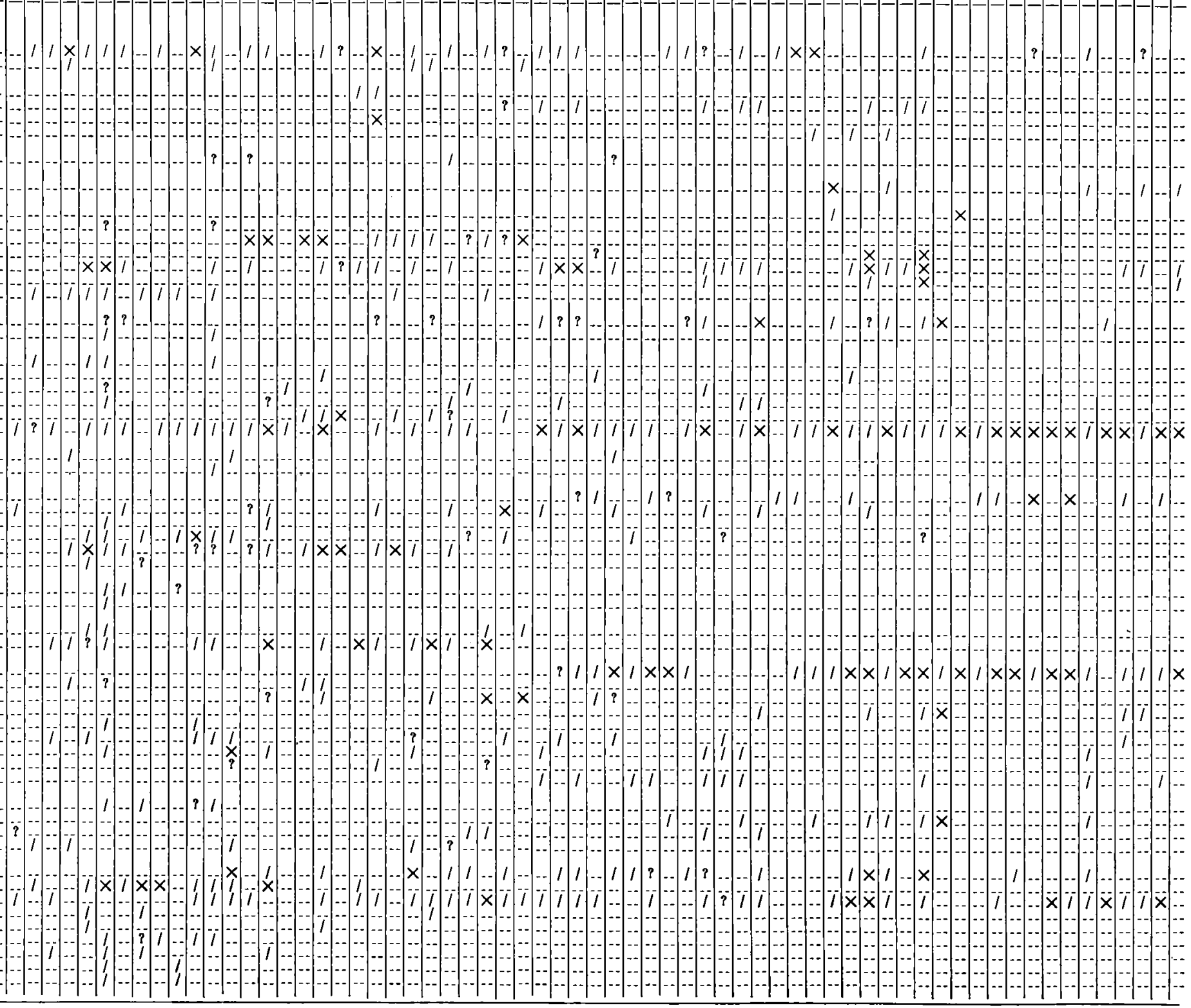


member, immediately above the sandy strata of the upper part of the lower member. Because the highest assemblage of Narizian age and the lowest assemblage of Refugian age are separated by 1,400 feet of unfossiliferous section, the boundary between these two stages cannot be placed precisely, and therefore, in this report, is questionably placed in the middle of the unfossiliferous part of the section. The following, whose lowest occurrence is above the unfossiliferous sandstone, are the more significant species of the Refugian stage:

\section{Quinqueloculina weaveri Rau \\ Nonion ef. N. pompilioides (Fichtel and Moll) \\ Bulimina alsatica. Cushman and Parker sculptilis laciniata Cushman and Parker}

Refugian Foraminifera occur throughout all but approximately the upper 300 feet of the middle member of the Twin River formation in the Lyre River section. Such species as Cancris joaquinensis Smith and Cassidulina globosa Hantken occur in the underlying strata of the Narizian stage as well as in the Refugian stage, but none occur in rocks of the overlying Zemorrian stage; therefore a combination of Narizian and Refugian species in an assemblage is used as evidence to differentiate faunas of the Refugian stage from those of the overlying Zemorrian stage. The base of the Zemorrian stage is indicated by the lowest occurrence of Bulimina cf. B. alsatica Cushman and Parker, Cassidulina crassipunctata Cushman and Hobson, and Sphaeroidina variabilis Reuss. The known occurrence of these species is limited to rocks no older than those assigned to the Zemorrian stage. Additional species that characterize the Zemorrian stage in the Pacific Northwest and which are also present in the Lyre River section are Entosolenia sp., Robulus cf. R. calcar (Linné), and Nonion incisum (Cushman).

A lower fauna and an upper fauna of the Zemorrian stage are recognized in the $T$ win River formation, but these two faunas do not necessarily correspond to the lower and upper faunas of the Zemorrian stage of Kleinpell in California. In the Lyre River section the lowest occurrence of the upper fauna of the Zemorrian stage is best indicated by the lowest occurrence of Nonion incisum (Cushman), about 100 feet below the top of the measured section.

\section{DEEP CREEK SECTION}

Foraminiferal assemblages from the Deep Creek section suggest an age no older than that of the Zemorrian stage (pl. 3). Foraminifera were not found in the lowest part of the formation in the Deep Creek section, but the lowest assemblages obtained resemble those of the lower part of the Zemorrian stage in the
Lyre River section. No Foraminifera characteristic of either the Refugian or the Narizian stage were found in the lower assemblages from the Deep Creek section. The occurrence of Cassidulina crassipunctata Cushman and Hobson in the lowest assemblages from the Deep Creek section is significant because this species not only is a common species in the Zemorrian stage throughout the Pacific Northwest, but its lowest occurrence is in the Lyre River section above the base of the Zemorrian stage. Bulimina cf. B. alsatica Cushman and Parker, although not a common form in the Twin River formation, is found also in the lower assemblages of the Deep Creek section. Its lowest occurrence in the Lyre River section is in the lowest beds assigned to the Zemorrian stage.

The lowest occurrence of Nonion incisum (Cushman) is a few hundred feet below the top of the measured section in Deep Creek and best marks the base of the upper part of the Zemorrian stage in this section. Buliminella subfusiformis Cushman, Bolivina marginata adelaidana Cushman and Kleinpell, and $U$ vigerina gallowayi Cushman also make their lowest occurrence in the uppermost part of the measured section in Deep Creek, and Eponides mansfieldi oregonensis Cushman and R. E. and K. C. Stewart was found in several samples in the upper half of the measured section. None of these species are abundant, but they are important because they rarely occur in rocks older than those assigned to the Zemorrian stage. Records of U. gallowayi Cushman are confined largely to rocks assigned to the Zemorrian stage.

\section{COAST SECTION}

Faunas of the upper part of the Zemorrian stage are well represented in the rocks exposed along the coast between the East Twin River and Murdock Creek, where a thick section of rocks is assigned to the upper part of this stage (pl. 4). Because in the area of this report the coastal section contains the most complete section of rocks assigned to the upper part of the Zemorrian stage, it is regarded as a reference section. Nonion incisum (Cushman) occurs at the base of the coastal section and is found throughout the lower half of this measured section. Elphidium cf. E. minutum (Reuss) is common in several samples from the upper part of the coastal section, and within the mapped area this species is known only from the upper part of the Zemorrian stage. Cassidulina crassipunctata Cushman and Hobson is present in a number of the samples from the coastal section and is regionally indicative of the Zemorrian stage. A high position in the Zemorrian stage is suggested by the presence of Bulimina alligata Cushman and Laiming, Uvigerina gallowayi Cushman, 
and Cassidulinoides sp. because of their common occurrence in the upper part of the Zemorrian stage in other regions of the Pacific Northwest.

\section{ISOLATED OUTCROPS}

Studies of foraminiferal assemblages from the Twin River formation are based chiefly on collections from the three measured sections, but faunas from these sections are augmented by many collections from scattered localities in other parts of the northern Olympic Peninsula. About 300 samples of Foraminifera were collected at random and 65 of these contain fossils that are useful in dating the containing rocks (table 3 ). The relative age of assemblages from these samples was determined by comparing them with faunas in the measured sections. The 65 samples from scattered localities contain assemblages that range in age from Narizian to late Zemorrian.

Assemblages referred to the Narizian stage are generally of two types. Some are similar to those of the Aldwell formation, but most are similar to assemblages that are believed to be younger than those of the Aldwell formation. However, the younger appearing assemblages do not always occur in the highest stratigraphic position. This anomalous condition may be due to reworking, or it may indicate that the fauna is more indicative of facies than of age.

The following species were not found in the measured sections but are present in assemblages from isolated outcrops. They are at least locally indicative of the Narizian stage and are useful in delimiting its upper extent.

\section{Quinqueloculina goodspeedi Beck \\ Robulus welchi Church \\ Bulimina corrugata Cushman and Siegfus \\ Valvulineria aff. V. jacksonensis persimilis Bandy Asterigerina crassiformis Cushman and Siegfus. Cibicides lobatus (d'Orbigny)}

Refugian, lower Zemorrian, and upper Zemorrian assemblages from isolated outcrops do not differ significantly from assemblages from the measured sections.

Characteristics of FaUNal UNITS

Faunal divisions in the Twin River formation are based primarily on observations of the Foraminifera in the Lyre River section. Additional and substantiating information was obtained from other sections and from isolated outcrops. Particular use was made of the observed range of species, the recorded range in other areas of species present in the Twin River formation, the association of species, and the frequency of occurrence of species.
Many species do not characterize any one faunal unit because they are found throughout the formation. Other species occur so rarely that their significance is not known. Species displaying the greatest significance are listed on figure 2. This figure shows the observed ranges, combination of occurrence, and frequency of occurrence of selected species. The frequency of occurrence of a species is given as a ratio, in percent, of the number of samples in which a given species occurred with respect to the total number of samples obtained from a given stage or stage subdivision. Because many more samples were available in the younger stages, the evidence concerning the limits of these stages and ranges of the species in them is much more reliable than is that concerning the relatively unfossiliferous lower part of the section. Therefore, the calculations shown on figure 2 should be considered only as a broad guide for determining which species are probably the most useful stratigraphically in the Twin River formation.

\section{REGIONAL CORRELATION}

Foraminiferal assemblages of the Twin River formation that are comparable to those referred to Mallory's Eocene Narizian stage are known in southwest Washington from an upper part of the McIntosh formation and parts of the Skookumchuck formation. There they are referred to either the Bulimina schencki-Plectofrondicularia cf. $P$. jenkinsi zone or the Uvigerina cf. U. yazooensis zone (Rau, 1958). In western Oregon similar assemblages are known from the Coaledo formation (Cushman, Stewart, and Stewart, 1947 , p. 57-69) and from a lower part of the Toledo formation (Cushman, Stewart, and Stewart, 1949), and they have been observed by the writer from parts of the Nestucca formation. In California similar assemblages are known from the Alhambra formation (Smith, 1957) and the Kreyenhagen shale (Cushman and Siegfus, 1942). Although faunas similar to those in both the lower and upper part of the Kreyenhagen shale are present in the Twin River formation, they do not necessarily occur in the same stratigraphic order as they do in the Kreyenhagen shale. In the Twin River formation these two faunas may represent two different environments or one of them may have been reworked into the Twin River formation from older rocks.

All the above-mentioned west coast assemblages have been referred to Laiming's A-1 or his A-2 zone of California. In the standard west coast section (Weaver and others, 1944) these zones are considered late Eocene in age (fig. 1). 


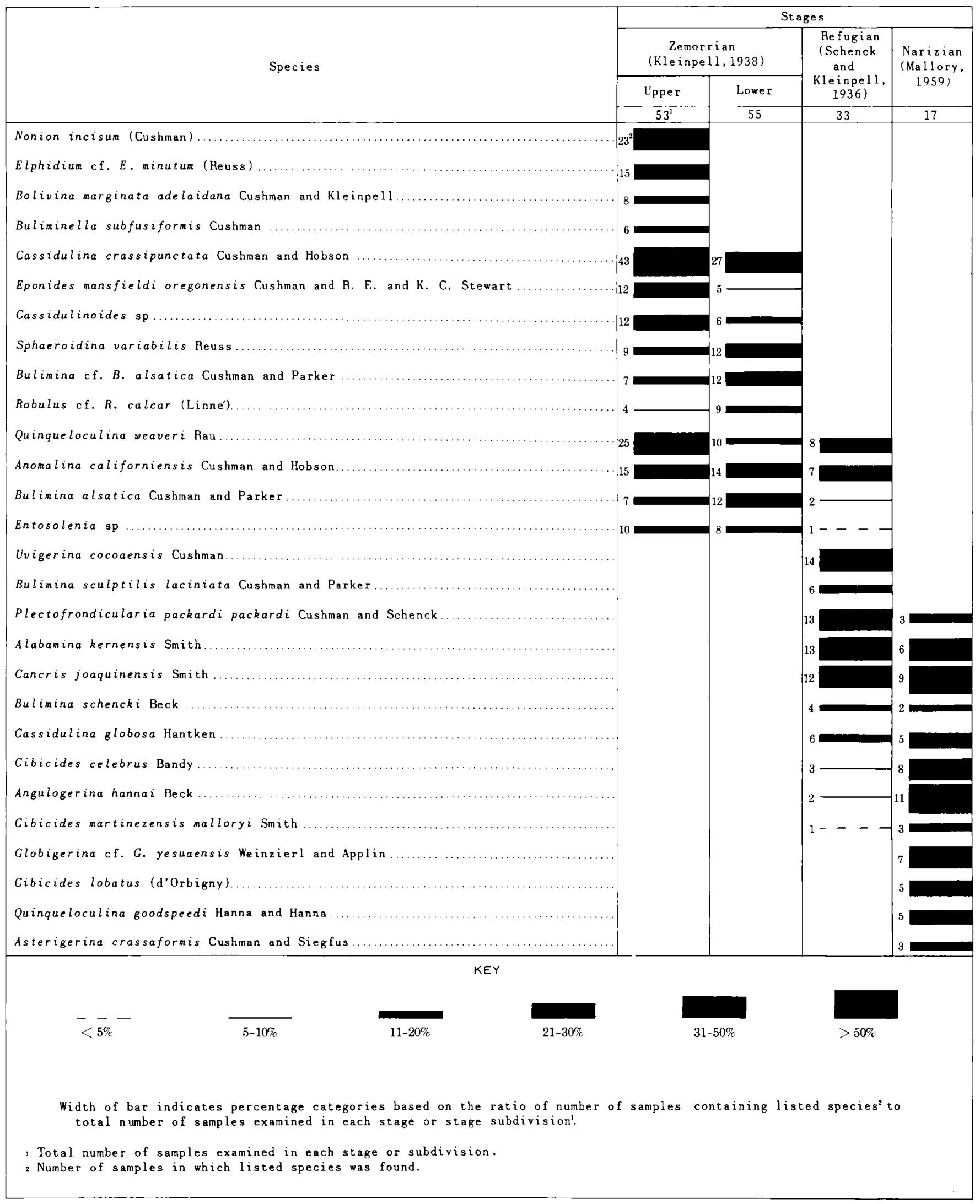

Figure 2.-Frequency of accurrence of selected species of Foraminifera in the Twin River formation. 
Twin River assemblages that are assigned to the Refugian stage are comparable with Refugian assemblages from the lower and middle part of the Lincoln formation of Weaver (1912) in southwest Washington, where they are referred to the Sigmomorphina schencki and Eponides kleinpelli zones (Rau, 1958). In western Oregon similar Refugian assemblages are known from the Keasey formation and Bastendorff shale (Cushman and Schenck, 1928; Detling, 1946) and they have been observed by the writer from a middle part of the Toledo formation near Waldport, Oreg. Comparable Refugian assemblages of California are known from the Tumey formation (Cushman and Simonson, 1944), the Gaviota formation (Wilson, 1954), and the Wagonwheel formation (Smith, 1956). In terms of the standard west coast section (Weaver and others, 1944), the Refugian stage is "Eo-Oligocene" and Oligocene in age.

Zemorrian assemblages similar to those of the Twin River formation are known from the upper part of Weaver's Lincoln formation in southwest Washington, where they are referred to the Pseudoglandulina aff. $P$. inflata zone (Rau, 1958), the upper part of the Toledo formation of western Oregon, and the upper part of the San Lorenzo formation of California (Cushman and Hobson, 1935). The Zemorrian stage is generally regarded as "Oligo-Miocene" in age.

\section{PALEOECOLOGY}

Only generalized interpretations can be made of the environment in which the Foraminifera of the Twin River formation lived because many of the species are extinct. Conclusions are necessarily based largely on the assumption that fossil species required the same environment as similar living species. Furthermore, data on many living species are incomplete and in some cases controversial. The following generalized interpretations are based on depth and temperature records of living species either identical with or similar to species known from the Twin River formation. Data on the depths and temperatures under which certain Foraminifera are known to live come from several independent records and, in many cases, are too numerous to cite in the discussion. The following references are cited as the major sources of depth and temperature data used in this report: Cushman (1927), Norton (1930), Natland (1933), Kleinpell (1938, p. 11-19, fig. 5), Glaessner (1947, p. 183-194), Parker (1948), Phleger and Parker (1951), Crouch (1952), and Bandy (1953). Particular attention has been given to species that were found in substantial numbers or that occurred persistently throughout thick sections of the formation. Because the occurrence of many species is rare or sporadic, the number of species used in determining paleoecology is limited.

The Foraminifera of the Twin River formation generally suggest an environment of deep cold water in an open sea. Gyroidina orbicularis planata Cushman is the most common and persistently occurring species known in the formation. Records of this species and similar species show that they prefer cold water at bathyal $(600$ to 6,000 feet) to abyssal ( 6,000 feet or more) depths. A similar environment is indicated by the commonly occurring species Uvigerina cocoaensis Cushman, $U$. garzaensis Cushman and Siegfus, and Cassidutina crassipunctata Cushman and Hobson. Although it is never found in large numbers, the planktonic form Globigerina is found in places and suggests that the mapped area may have had reasonably good access to an open sea.

Although the evidence is not conclusive, Foraminifera from the lower part of the formation suggest a more shallow environment than do the Foraminifera from the middle and much of the upper part of the formation. Angulogerina and certain species of Cibicides that are similar to species generally recorded from upper bathyal and neritic depths (approximately 2,000 feet to tidal depth) were found in many of the samples from the lower part of the formation. Deepwater species, such as Gyroidina orbicularis planata, also are present. The depth at which the combination of species from the lower part of the Twin River formation lived is therefore estimated as moderate, uppermost bathyal to lower neritic (approximately 1,000 to 300 feet).

Several assemblages from isolated localities within the lower part of the formation are comparable to the cold-, deep-water fauna of the Aldwell formation and may have been reworked into the Twin River formation. However, if they lived during the deposition of the Twin River formation, a depth greater than 1,000 feet may have also existed in local areas during deposition of the lower part of the formation.

Costate Uvigerina, Plectofondicularia, and Nonion pompilioides suggest bathyal depths (6,000 to 600 feet), whereas Cancris and Alabamina are recorded from cold but shallower water. These Foraminifera occur together in the middle and in much of the upper part of the Twin River formation and suggest bathyal depths, between 6,000 and 1,000 feet.

During the deposition of the uppermost part of the upper member of the Twin River formation, depths probably were decreased but water temperatures remained at least cool. Gyroidina, together with several other forms characteristic of bathyal to lower neritic depths, persist throughout the middle and upper members of the formation. However, Elphidium cf. $E$. 
minutum (Reuss) and Nonion incisum (Cushman) become common in the fauna of the uppermost part of the upper member of the formation. Foraminifera of this type suggest shallow-water conditions. $N$. incisum suggests cool temperatures in a somewhat sheltered environment. Cool conditions are further suggested by the presence of abundant Cassidulina of the type that is found in cool water of Recent seas. Although the uppermost part of the formation does contain some deepwater Foraminifera the greater abundance of shallow forms here than in any other part of the formation suggests that the water became more shallow but that the temperature remained cool. Probably in the final stages of deposition of the Twin River formation upper neritic depths became dominant, a prelude to distinct neritic conditions that prevailed during the deposition of the overlying Clallam formation.

\section{FORAMINIFERA FROM THE CLALLAM FORMATION}

The known foraminiferal fauna of the Clallam formation consists of 11 species (table 4) collected from three localities (f11891, f11892, f11893) in the northwest part of the mapped area.

TABLE 4.-Foraminifera from the Clallam formation [X, abundant to common; /, few to rare; ?, questionably identified]

\begin{tabular}{|c|c|c|c|}
\hline \multirow{2}{*}{ Species (arranged taxonomically) } & \multicolumn{3}{|c|}{ Locality (pl. 1) } \\
\hline & f11891 & fl1 1892 & f11893 \\
\hline Triloculina sp...- & & 1 & \\
\hline $\begin{array}{l}\text { Robulus sp } \\
\text { Nonion costiferum (Cushman) } \\
\text { incisum (Cushman) }\end{array}$ & $x$ & $x$ & ' $x$ \\
\hline $\begin{array}{l}\text { Elphidium ef. E. minuthum (Reuss) } \\
\text { Bulimina ef. B. ovata d Orbigny } \\
\text { Blivinina advena Cushman } \\
\text { Valvulineria cf. V. depressa Cushman } \\
\text { Gyroidina orbicularis planata Cushman }\end{array}$ & \begin{tabular}{l}
$-\cdots$ \\
\hdashline \\
\hdashline \\
\hdashline-1 \\
\hdashline-1
\end{tabular} & $\begin{array}{l}x \\
x \\
1 \\
1 \\
x\end{array}$ & 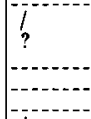 \\
\hline $\begin{array}{l}\text { Eponides mansfieldi oregonensis Cushman and R. E. and } \\
\text { K. C. Stewart. } \\
\text { nnomalina californiensis Cushman and Hobson.......... }\end{array}$ & & $\dot{x}$ & $T^{-}$ \\
\hline
\end{tabular}

Although the fauna is small, it nevertheless is indicative of age. Nonion costiferum makes its lowest occurrence within the area at the base of the Clallam formation. According to Kleinpell (1938, p. 116), $N$. costiferum makes its first occurrence in the Saucesian stage of California. This statement is substantiated by observations of the writer in Oregon and in southwestern Washington. In southwestern Washington it makes its lowest occurrence in the Epistominella parva zone (Rau, 1958), which occurs largely in strata mapped as the lower part of the Astoria(?) formation (Snavely and others, 1958; Pease and Hoover, 1957). In western Oregon its lowest known occurrence is near the base of the Nye mudstone in the Yaquina Bay area. The foraminiferal faunas of both the lower part of the Astoria (?) formation and the Nye mudstone are considered to be of Saucesian age by the writer. Both
Bolivina advena Cushman and Valvulineria cf. V. depressa Cushman support a Saucesian age even though thev occur in small numbers in the Clallam formation.

The upper age limit of the known foraminiferal fauna of the Clallam formation is not as strongly indicated. Anomalina californiensis makes a rare occurrence at one locality. This species is little known above the lower part of the Saucesian stage. A Saucesian age for at least the lower part of the Clallam formation is further suggested by stratigraphic evidence because in places the Clallam formation rests conformably on Zemorrian age strata of the Twin River formation (Gower, 1960). Foraminifera were not collected from the uppermost part of the Clallam formation and therefore the age of that part of the formation was not determined on the basis of Foraminifera. The Saucesian stage of the standard west coast section (Weaver and others, 1944) is regarded as "Oligo-Miocene" in age.

The small foraminiferal fauna of the Clallam formation is also suggestive of the environment in which it lived, probably a shallow, cool, and somewhat sheltered sea. Nonion costiferum is common in samples from the three localities. Kleinpell (1938, p. 15; and table 1) inferred that this species is common in neritic waters and in areas sheltered from current action. Furthermore, Kleinpell (1938, fig. 5) considered the genus Nonion to be a cool-temperate-water form. Elphidium cf. E. minutum is also common in the Clallam fauna. Species similar to it are almost always found at shallow depths (Phleger and Parker, 1951, pt. 2, p. 10). Eponides mansfieldi oregonensis occurred at all three Clallam localities. This species is similar to $E$. hannai, which Phleger and Parker (1951, pt. 1, p. 51) indicated is confined to depths of less than 100 meters in the northwest part of the Gulf of Mexico. Gyroidina orbicularis planata, which occurred at one locality in the Clallam formation, is the only conflicting evidence for a shallow depth, because records of this species are usually from greater depths. However, its known preference for cold water suggests cool-water conditions as suggested by Nonion. The remaining species from the Clallam formation occur too rarely, or their recorded environments are too varied, to be suggestive of the probable environment.

\section{SUMMARY OF PALEOECOLOGIC INTERPRETATIONS BASED ON FORAMINIFERA}

The abundance of planktonic Foraminifera known from parts of the Crescent formation suggests that sometime following the Cretaceous period and prior to late early Eocene or middle Eocene time, open-sea conditions probably prevailed in the area. The absence of benthonic forms in these assemblages suggests that 
the environment was unfavorable for the existence of bottom-dwelling Foraminifera. The distribution of planktonic Foraminifera is largely dependent upon ocean currents; therefore, their presence in the Crescent formation suggests that they were brought into the area even though conditions were not continuously favorable for their existence. The concentrations of planktonic foraminiferal remains in certain places in the formation suggest periodic annihilation. Conditions for mass destruction of planktonic Foraminifera could have resulted from extensive submarine volcanic activity that is indicated by the numerous pillow basalt flows in the Crescent formation.

In late early to middle Eocene time shallow protected bays existed at least during the deposition of the upper part of the Crescent formation, as is indicated by the presence of benthonic Foraminifera that required shallow, warm, clear water. These conditions may have resulted from the extrusion of volcanic material to the extent that the seas became shallow and in places broken by barrier reefs or islands.

In the early part of late Eocene time the area probably underwent considerable subsidence, because all foraminiferal assemblages known from the overlying Aldwell formation indicate a cool, deep-water environment. This postulation is supported by the almost total absence of megafossils and the fine-grained nature of the sediments of the formation.

The absence of Foraminifera in the overlying Lyre formation may be due to a rapid deposition of the coarse clastic sediments of this formation. Such sediments most probably were deposited under turbulence which, in turn, would have created muddy seas, a condition unfavorable for most Foraminifera.

Following the deposition of the Lyre formation and during late Eocene time, the lower part of the Twin River formation was probably deposited at various depths, but generally in a moderately shallow sea. If the Aldwell-like assemblages, found in a few places in the lower part of the Twin River formation, were not reworked, considerable depths existed locally in the area during that time. However, generally the Foraminifera of the lower part of the Twin River formation suggest moderately shallow depths, uppermost bathyal to lower neritic.

By Refugian time (late Eocene or early Oligocene), deepening of the sea continued, although in places, particularly to the west, moderately shallow depths continued to prevail.

Maximum depths of deposition for the Twin River formation were probably attained throughout most of the mapped area during the early part of Zemorrian time (late Oligocene or early Miocene). The Forami- nifera suggest that the sea was shallowest in the western part of the area but that it gradually deepened during Zemorrian time. By the close of Zemorrian time the sea rapidly became more shallow.

The much greater thickness and generally coarser grained nature of the Twin River formation in the vicinity of Deep Creek, as compared to the formation in the Lyre River area, suggest that a source of sediments may have been closer to the Deep Creek area than to the Lyre River area. Furthermore, combined information on the paleoecology and age inferred by Foraminifera suggests that shallow conditions existed for a longer period of time in the Deep Creek area than they did in the Lyre River area.

In the Deep Creek section, foraminiferal information is a vailable only from the middle member, a lithologic unit primarily of bedded siltstone and sandstone. Foraminifera indicate that all but the upper 500 feet of this member is early Zemorrian in age. The upper 500 feet is late Zemorrian in age. In the Lyre River section to the east all the Foraminifera of the middle member, except those from the upper 300 feet of the member, are Refugian in age. Foraminifera from the upper 300 feet of the middle member and those from almost all the upper member in the Lyre River section are of early Zemorrian age. The upper member of the formation is chiefly mudstone. Therefore, the siltstone and sandstone of the middle member were deposited during the Refugian time in the Lyre River area, whereas in the Deep Creek area their deposition continued throughout much of Zemorrian time to the west. The sediments of the middle member not only were deposited for a longer period of time in the Deep Creek area, but their greater thickness in a unit of time indicates they also accumulated more rapidly there than they did to the east in the Lyre River area.

These comparisons show that, although the three members of the Twin River formation maintain a stratigraphic sequence, the geologic age as well as the amount of time represented by any one member can vary throughout the mapped area.

Limited foraminiferal eridence indicates that during Saucesian time (early Miocene) at least part of the Clallam formation was deposited under shallow, coolwater conditions in a protected environment. Coal beds in the upper part of the Clallam formation indicate that other parts of the formation are continental deposits.

\section{IDENTIFIED SPECIES}

\section{SYSTEMATIC DISCUSSION}

Discussions and illustrations are restricted to 42 species that display either stratigraphic or paleoecologic significance in the northern Olympic Peninsula. A 
complete synonomy of each species is not attempted, but rather pertinent references are listed, one of which will supply a more complete synonomy.

The frequent use of qualifiers such as "cf." and "aff." has been necessary because many forms are represented by few specimens and many specimens are poorly preserved.

\section{Family VALVULINIDAE}

\section{Genus TRItaxirina Cushman, 1911}

Tritaxilina colei Cushman and Siegfus

Plate 5, figure 2

Tritaxilina colei Cushman and Siegfus, 1935, Cushman Lab. Foram. Research Contr., v. 11, pt. 4, p. 92, pl. 14, figs. 5,6 .

Cushman and Siegfus, 1942, San Diego Soc. Nat. History Trans., v. 9, no. 34, p. 403, pl. 15, figs. 12, 13.

Mallory, 1959, Lower Tertiary biostratigraphy of the California Coast Ranges: Am. Assoc. Petroleum Geologists, p. 128, pl. 27, fig. 9 .

This species is present in a few samples from the Aldwell formation and the lower part of the Twin River formation. It was originally described from the Kreyenhagen shale (Cushman and Siegfus, 1935) and has since been recorded from California throughout rocks of Eocene age.

Figured specimen (USNM 626981) from USGS locality f11884.

\section{Family MIIIOLIDAE}

\section{Genus QUTNQUELOCULINA d'Orbigny, 1826}

Quinqueloculina goodspeedi Hanna and Hanna

Plate 5, figure 1

Quinqueloculina goodspeedi Hanna and Hanna, 1924, Washington Univ. [Seattle] Pub. Geology, v, 1, no. 4, p. 58, pl. 13 , figs. 3,4 .

Beck, 1943, Jour. Paleontology, v. 17, no. 6, p. 592, pl. 99 figs. $1,2$.

Rau, 1951, Jour. Paleontology, v. 25, no. 4, p. 429, pl. 63, figs. $6-8$.

This species is characterized by its elongate shape, rounded cross section, and a slightly protruding, round aperture with a thin tooth extending from the base. Although it is uncommon in the mapped area, it is useful when present because it indicates a late Eocene age in western Washington. It is known from the Cowlitz formation (Beck, 1943), the Skookumchcuk formation, and the upper part of the McIntosh formation of southwestern Washington (Rau, 1958). It occurs in the lower part of the Twin River formation in the northern Olympic Peninsula.

Figured specimen (USNM 626982) from USGS locality f11874.
Quinqueloculina weaveri Rau

Plate 5, figure 3

Quinqueloculina weaveri Rau, 1948, Jour. Paleontology, จ. 22, no. 2, p. 159, pl. 28, figs. 1-3.

Rau, 1951, Jour. Paleontology, v. 25, no. 4, p. 430, pl. 63, fig. 4.

Quinqueloculina weaveri differs from $Q$. goodspeedi in that its cross section is more angular, the apertural face slopes, and the base of the aperture is flattened. This species usually occurs in rocks of the Refugian stage, but it is also found in the northern Olympic Peninsula in rocks assigned to the Zemorrian stage.

Figured specimen (USNM 626983) from USGS locality f11793.

\section{Family IAGENIDAE}

Genus ROBULUS Montfort, 1808

Robulus cf. R. calcar (Linné)

Plate 5, figure 4

Robulus ef. $R$. calcar (Linné). Rau, 1951, Jour. Paleontology, v. 25 , no. 4, p. 431, pl. 63, figs. $23,24$.

Angular areas are present on the periphery of some specimens of Robulus where the periphery is joined by the sutures. Blunt spines even are formed at these angular areas on some specimens. All specimens displaying these features are tentatively and in a broad sense referred to R. calcar (Linné). This general form seems to be a good marker fossil for rocks of the Zemorrian stage in western Washington and Oregon because it is recorded only from rocks of this age in southwestern Washington (Rau, 1958) and is known from the rocks of the same age in western Oregon. It occurs in the upper part of the Twin River formation in the northern Olympic Peninsula.

Figured specimen (USNM 626984) from USGS locality f11754.

\section{Robulus welchi Church \\ Plate 5, figure 6}

Robulus welchi Church, 1931, California Dept. Nat. Resources, Div. Mines Rept. State Mineralogist. No. 27, pl. C, figs. $13,14$.

Church, 1943, California Dept. Nat.. resources, Div. Mines Bull. 118, p. 182.

Mallory, 1959, Lower Tertiary biostratigraphy of the California Coast Ranges: Am. Assoc. Petroleum Geologists, p. 143, pl. 7, fig. 8.

Because of poor preservation, identification of this species is based on a group of specimens rather than a single individual. The species is not common but is present in a few samples from the Aldwell formation and the lower part of the Twin River formation. In western Washington and Oregon this species is known 
only from rocks of late Eocene age. California records are also all from strata of late Eocene age (Mallory, 1959 , p. 143).

Figured specimen (USNM 626985) from USGS locality f11726.

\section{Family NONIONIDAE}

Genus NONION Montfort, 1808

Nonion costiferum (Cushman)

Plate 5, figure 5

Nonionella boueane Chapman (not d'Orbigny), 1900, California Acad. Sci. Proc., ser. 3, Geology, v. 1, p. 225, pl. 30, fig. 14.

Nonion costiferum (Cushman). Kleinpell, 1938, Miocene stratigraphy of California : Am. Assoc. Petroleum Geologists, p. 229 , pl. 15, fig. 13 .

Rau, 1948, Jour. Paleontology, v. 22, no. 6, p. 777, pl. 119, figs. 5,6 .

Rau, 1951, Jour. Paleontology, v. 25, no. 4, p. 436, pl. 64, fig. 7.

This species is common in all samples from the Clallam formation but was not found in any of those below the formation. It is recorded from many localities of Miocene age in California, Oregon, and Washington (Kleinpell, 1938). The lowest occurrence of Nonion costiferum generally coincides with the base of the Saucesian stage. Therefore its lowest occurrence in the northern Olympic Peninsula at the base of the Clallam formation suggests a Saucesian age for at least the lower part of the formation.

Figured specimen (USNM 626986) from USGS locality f11891.

\section{Nonion incisum (Cushman)}

Plate 5, figure 9

Nonionina incisa Cushman, 1926, Cushman Lab. Foram. Research Contr., v. 1, pt. 4, p. 90, pl. 13, fig. 3.

Nonion incisa (Cushman). Cushman and Laiming, 1931, Jour. Paleontology, v. 5, no. 2, p. 104, pl. 11, fig. 10.

Nonion incisum (Cushman). Cushman and Parker, 1931, Cushman Lab. Foram. Research Contr., v. 7, pt. 1, p. 7, pl. 1, fig. 26.

Cushman and LeRoy, 1938, Jour. Paleontology, จ. 12, no. 2, p. 125 , pl. 22 , figs. 8,9 .

Many variations are shown among the specimens that are referred to this species. Some of the more conspicuous variations are in the amount of flaring of the latter chambers, the height relative to breadth, the thickness, and the amount of depression of sutures. Regardless of these variations, all specimens fall within the limits of the species sensu lato.

Nonion incisum is a useful fossil in the northern Olympic Peninsula because there it is known to occur only in the upper part of the Zemorrian stage and the Saucesian stage where it is reasonably frequent.
Variations of the species have been recorded from California and Oregon from rocks referred to the upper part of Kleinpell's Zemorrian stage and to the lower part of his Luisian stage (Kleinpell, 1938, p. 146, 232, 233).

Figured specimen (USNM 626987) from USGS locality f11731.

\section{Nonion cf. N. pompilioides (Fichtel and Holl)}

Plate 5, figure 7

Forms displaying bilateral symmetry and a broad final chamber are tentatively referred to Nonion pompitioides (Fichtel and Moll). (See Cushman, 1939, p. 19, pl. 5, figs. 9-12.) Most of the specimens came from rocks of the Zemorrian stage; however, a few specimens were also found in rocks of the Refugian stage.

Figured specimen (USNM 626988) from USGS locality f11749.

\section{Genus ELPHIDIOM Montfort, 1808 \\ Elphidium cf. E. minutum (Reuss) \\ Plate 5, figure 8}

The description of this species given by Cushman $(1939$, p. 40) agrees closely with that of a number of specimens from the upper part of the rock sequence of the northern Olympic Peninsula. However, his illustrations (Cushman, 1939, pl. 10, figs. 22-25) all display coarser retral processes than are developed on the specimens under question. Inasmuch as Cushman stated that the retral processes are very slightly developed, they may have been overemphasized in his illustrations.

Elphidium cf. E. minutum was found only in rocks assigned to the upper part of the Zemorrian stage and the Saucesian stage within the mapped area. It is also recorded from rocks of Zemorrian and Saucesian age in southwestern Washington (Rau, 1951, 1958).

Figured specimen (USNM 626989) from USGS locality f11891.

\section{Family HETEROHELICIDAE}

\section{Genus PLECTOFRoNDICULARIA Liebus, 1903}

Plectofrondicularia packardi multilineata Cushman and Simonson

Plate 5, figure 15

Plectofrondicularia packardi multilineata Cushman and Simonso, 1944, Jour. Paleontology, v. 18, no. 2, p. 197, pl. 32, figs. $2-4$.

Detling, 1946, Jour. Paleontology, v. 20, no. 4, p. 355, pl. 49 , figs. 3,5 .

Rau, 1948, Jour. Paleontology, v. 22, no. 2, p. 171, pl. 30, fig. 19.

Smith, 1956, California Univ. Dept. Geol. Sci. Bull., v. 32, no. 2, p. 94, pl. 12, fig. 6 . 
Plectofrondicularia graoilis Smith, 1956, California Univ. Dept. Geol. Sci. Bull., v. 32, no. 2, p. 93, pl. 12, figs. 2-5.

The Tertiary sequence of Washington, Oregon, and California contains a strain of Plectofrondicularia which displays considerable variation in form. The variant most significant stratigraphically was originally described from the Bastendorff shale of Oregon and called P. packardi Cushman and Schenck (1928). Subsequently a more common and widely distributed variant was described from the Tumey formation of California and referred to $P$. packardi multilineata Cushman and Simonson (1944). Studies of the faunas of the Tertiary rocks of Oregon and Washington strongly suggest that there, at least, $P$. packardi packardi does not occur above the Refugian stage and is found only occasionally in the underlying Narizian stage. However, $P$. packardi multilineata occurs throughout rocks of late Eocene, Oligocene, and possibly early Miocene age. Many variants of the strain displaying a complete gradation from one form to another were found in samples from the northern Olympic Peninsula. Those referred to $P$. packardi packardi have few short and coarse costae which are sometimes curved on the initial chamber. The remaining forms of various shapes with varying number of straight and longer costae are referred to $P$. packardi multilineata. Certain variances in the latter group have been examined for stratigraphic value and have been found to be of no importance. Therefore, they are all grouped under the single name $P$. packardi multilineata in this study. $P$. gracilis Smith is within this group and is placed in synonomy with $P$. packardi multilineata in the report.

Figured specimen (USNM 626990) from USGS locality f11736.

Plectofrondicularia packardi packardi Cushman and schenck

Plate 5, figure 13

Plectofrondirularia pacleardi Cushman and Schenck, 1928, California Univ. Dept. Geol. Sci. Bull., r. 17, no. 9, p. 311, pl. 43; figs. 14-15.

Cushman and Simonson, 1944, Jour. Paleontology, v. 18, no. 2, p. 197, pl. 31, figs. 17,18 , pl. 32, fig. 1 .

Detling, 1946, Jour. Poleontology, v. 20, no. 4, p. 355, pl. 49, fig. 1.

Rau, 1951, Jour. Paleontology v. 25, no. 4, p. 438, pl. 65, fig. 12.

Wilson, 1954, California Univ. Pub. Geol. Sci. Bull., v. 30, no. 2 , p. 138 , pl. 15 , fig. 8 .

Smith, 1956, California Lniv. Pub. Geol. Sci. Bull., v. 32, no. 2 , p. 94 , pl. 12 , figs. 1,7 .

Discussion of this species is under Plectoforndicularia packardi multilineata.

Figured specimen (USNM 626991) from USGS locality f11876.
Family BULIMINIDAE

Genus BULIMINELLA Cushman, 1911

Buliminella subfusiformis Cushman

Plate 5, figure 12

Buliminella subfusiformis Cushman, 1925, Cushman Lab. Foram. Research Contr., v. 1, pt. 2, p. 33, pl. 5, fig. 12.

Cushman, Stewart, and Stewart, 1947, Oregon Dept. Geology and Mineral Industries Bull. 36, pt. 1, p. 17, pl. 2, fig. 7 .

Rau, 1951, Jour. Paleontology, v. 25, no. 4, p. 439, pl. 65, fig. 5.

This species occurs rarely in the rocks of the northern Olympic Peninsula, only in the upper part of the Twin River formation. Records of Buliminella subfusiformis in Washington, Oregon, and California strongly suggest that it does not occur in rocks older than those of the Zemorrian stage. In southwest Washington it is recorded from the Pseudoglandulina aff. $P$. inflata zone and the Epistominella parva zone (Rau, 1958) of the Zemorrian and Saucesian stages, respectively. It is known in Oregon from the Astoria formation (Cushman, Stewart, and Stewart, 1947) and the Nye mudstone. In California, Kleinpell (1938) recorded this species from the lower part of the Zemorrain stage to the lower part of the Delmontain stage.

Figured specimen (USNM 626992) from USGS locality f11867.

Genus BULIMINA d'Orbigny, 1826

Bulimina corrugata Cushman and Siegfus

Plate 5, figure 11

Bulimina corrugata Cushman and Siegfus, 1936, Cushman Lab. Foram. Research Contr., v. 11, pt. 4, p. 92, pl. 14, fig. 7. Graham and Classen, 1955, Cushman Found. Foram. Research Contr., v. 6, pt. 1, p. 19, pl. 3, flg. 17.

Rau, 1956, Cushman Found. Foram. Research Contr., v. 7. pt. 3 , p. 75 , pl. 15 , fig. 5 .

The present specimens are small, tend to be triangular in cross section, display the greatest breadth slightly above the middle, and have numerous longitudinal costae extending continuously over all but the last chamber. These features characterize Bulimina corrugata as described by Cushman and Siegfus.

This species was found locally in the Crescent and Aldwell formations and the lower part of the Twin River formation. In southwest Washington it is recorded from the Bulimina cf. B. jacksonensis zone and the Uvigerina cf. $U$. yazooensis zone of McIntosh formation (Rau, 1956, 1958). In Oregon it has been observed by the writer in samples from the Umpqua formation, lower part of the Toledo formation, Nestucca formation, Yamhill formation, and the Elkton siltstone member of the Tyee formation. The highest occurrence of $B$. 
corrugata in both Oregon and Washington is generally in the lower part of the sequence of late Eocene age. According to Mallory (1959), B. corrugata occurs in California in rocks ranging in age from his Ulatisian stage to his Narizian stage.

Figured specimen (USNM 626993) from USGS locality f11886.

\section{Bulimina lirata Cushman and Parker}

Plate 5, figure 17

Bulimina lirata Cushman and Parker, 1936, Cushman Lab. Foram. Research Contr., v. 12, pt. 2, p. 43, pl. 8, fig. 2.

Cushman and Simonson, 1944, Jour. Paleontology, v. 18, no. 2, p. 198, pl. 32, fig. 13.

Smith, 1957, California Univ. Pub. Geol. Sci., v. 32, no. 3, p. 174, pl. 24, flg. 13.

Mallory, 1959, Lower Tertiary biostratigraphy of the California Coast Ranges, Am. Assoc. Petroleum Geologists, p. 193, pl. 37, fig. 1 .

Bulimina cf. B. lirata Cushman and Parker. Cushman and Siegfus, 1942, San Diego Soc. Nat. History Trans., v. 9, no. 34, p. 413, pl. 17, fig. 3 .

A few costate specimens of Bulimina are relatively broad with respect to length and taper rapidly to a sharp initial end. They compare well in all respects to $B$. lirata Cushman and Parker, which, according to Mallory $(1959$, p. 85 ), is known from his Penutian, Ulatisian, and Narizian stages of the upper part of the Eocene sequence of California.

This species has not been recorded previously from Washington or Oregon but has been observed by the writer in samples from the Umpqua formation and rocks of probable equivalent age in Oregon. In the northern Olympic Peninsula it was found in a few samples from both the Aldwell formation and the lower part of the Twin River formation.

Figured specimen (USNM 626994) from USGS locality f11873.

\section{Bulimina alsatica Cushman and Parker}

Plate 5, figure 16

Bulimina alsatica Cushman and Parker, 1937, Cushman Lab. Foram. Research Contr., v. 13, pt. 1, p. 39, pl. 4, figs. 6, 7. Cushman and Parker, 1947, U.S. Geol. Survey Prof. Paper $210-\mathrm{D}$, p. 102 , pl. 24 , figs. 10,11 .

A small, comparatively broad Bulimina with jagged costae over all chambers except those of the last whorl compares well with the illustrations and description of B. alsatica Cushman and Parker. This species is known from rocks of Oligocene age in France and Germany and from rocks of Miocene age in Italy, Spain, and Florida. It has also been tentatively recorded from rocks of Oligocene age in Washington (Rau, 1958). In the Twin River formation it occurs most frequently in rocks that are assigned to the Zemorrian stage. It also makes a rare occurrence in the Refugian part of the Twin River formation.

Figured specimen (USNM 626995) from USGS locality f11749.

\section{Bulimina cf. B. alsatica Cushman and Parker}

Plate 5, figure 14

This form differs from Bulimina alsatica in that costae do not extend as far up on the test and the costae appear to be pointed projections on the base of the chambers rather than platelike costae over the entire chamber. This form is found together with $B$. alsatica in the upper part of the Twin River formation.

Figured specimen (USNM 626996) from USGS locality $\mathbf{f} 11815$.

\section{Bulimina schencki Beck}

Plate 5, figure 10

Bulimina capitata? Cushman and Dusenbury (not Yokoyama), 1934, Cushman Lab. Foram. Research Contr., v. 10, pt. 3, p. 61, pl. 8, fig. 10 .

Bulimina schencki Beck, 1943, Jour. Paleontology, v. 17, no. 6, p. 605 , pl. 107 , figs. 28,33 .

Mallory, 1959, Lower Tertiary biostratigraphy of the California Coast Ranges: Am. Assoc. Petroleum Geologists, p. 196, pl. 16, fig. 15 .

A few specimens were found in the lower part of the Twin River formation that display all the characteristics of Bulimina schencki. One specimen questionably identified as this species came from the Crescent formation.

Bulimina schencki Beck (1943) was originally described from the Cowlitz formation of southwest Washington and has been recorded since from the Skookumchuck formation of the same area (Rau, 1958). In California Mallory (1959) recorded this species from the upper part of his Ulatisian stage and his Narizian stage. It has been found in the Poway conglomerate, Cozy Dell formation, Point of Rocks formation, and the type Tejon formation (Mallory, 1959).

Figured specimen (USNM 626997) from USGS locality $\mathrm{f} 11875$.

Bulimina sculptilis laciniata Cushman and Parker

Plate 6, figure 1

Bulimina sculptilis Cushman. Cushman and Schenck, 1928, California Univ. Dept. Geol. Sci. Bull., v. 17, no. 9, p. 311, pl. 43 , fig. 16.

Bulimina sculptilis laciniata Cushman and Parker, 1987, Cushman Lab. Foram. Research Contr., v. 13, pt. 1, p. 38, pl. 4, fig. 4.

Rau, 1951, Jour. Paleontology, v. 25, no. 4, p. 441, pl. 65, fig. 22. 
This large Butimina with continuous, jagged, and platelike costae was found only in strata of the Twin River formation that are referred to the Refugian stage. It was originally described from beds at Waldport, Oreg., which are regarded as Zemorrian in age by the writer. It is also known in Oregon from the Bastendorff shale and the Keasey formation (Cushman and Schenck, 1928) of Refugian age. The southwestern Washington occurrences are from the Sigmomorphina schencki zone of the Refugian stage and the Bulimina schencki-Plectofrondicularia cf. $P$. jenkinsi zone of latest Eocene age (Rau, 1958). Although the species is found occasionally both above and below the Refugian stage, its occurrence is most frequent in the Refugian stage.

Figured specimen (USNM 626998) from USGS locality f11865.

\section{Genus ENTOSOLENIA Ehrenberg, 1848 \\ Entosolenia sp. \\ Plate 6, figure 2}

Test broadly ovate, slightly compressed, walls smooth, finely perforate; aperture a narrow slitlike opening. Length of figured specimen $0.35 \mathrm{~mm}$; breadth $0.29 \mathrm{~mm}$; thickness $0.23 \mathrm{~mm}$.

This form is uncommon in rocks of the northern Olympic Peninsula. Its known occurrence is confined largely to strata of Zemorrian age in the Twin River formation and therefore locally, at least, it has stratigraphic significance.

Figured specimen (USNM 626999) from USGS locality f11751.

\section{Genus BoLIVINA d'0rbigny, 1839}

Bolivina advena Cushman

Plate 6, figure 4

Bolivina advena Cushman, 1925, Cushman Lab. Foram. Research Contr., v. 1, pt. 2, p. 29, pl. 5, fig. 1.

Kleinpell, 1938, Miocene stratigraphy of California: Am. Assoc. Petroleum Geologists, p. 264, pl. 7, fig. 6.

Cushman, Stewart, and Stewart, 1947, Oregon Dept. Geology and Mineral Industries Bull. 36, pt. 1, p. 18, pl. 2, fig. 12.

Rau, 1951, Jour. Paleontology, v. 25, no. 4, p. 442, pl. 65, fig. 9.

This species is rare in the present material. It occurs only in the uppermost part of the Twin River formation and the Clallam formation. It is known in southwest Washington from the Epistominella parva zone (Rau, 1958), and in Oregon it is recorded from the Astoria formation (Cushman, Stewart, and Stewart, 1947). The species is known in California from rocks ranging in age from that of the Saucesian stage to the Mohnian stage (Kleinpell, 1938). In the northern Olympic Peninsula the presence of Bolivina advena in the rocks suggests a relatively high stratigraphic position in the local Tertiary sequence.

Figured specimen (USNM 627000) from USGS locality f 11749 .

Bolivina marginata adelaidana Cushman and Kleinpell

$$
\text { Plate 6, figure } 8
$$

Bolivina marginata adelaidana Cushman and Kleinpell, 1934, Cushman Lab. Foram. Research Contr., v. 10, pt. 1, p. 10, pl. 2, figs. 1, 2.

Cushman, Stewart, and Stewart, 1947, Oregon Dept. Geology and Mineral Industries Bull. 36, pt. 1, p. 18, pl. 2, fig. 13.

Rau, 1951, Jour. Paleontology, v. 25, no. 4, p. 443, pl. 65, fig. 14.

The spinelike extension of the chambers at the periphery and limbate sutures are well developed on the present specimens. This form occurs in rocks of Zemorrian age in the Twin River formation. In western Washington and Oregon it occurs only in strata that are no older than those of the Zemorrian stage. It is recorded from the Pseudoglandulina aff. $P$. inflata zone and Epistominella parva zone of southwestern Washington (Rau, 1958). In Oregon it is known from the Astoria formation (Cushman, Stewart, and Stewart, 1947 ) and it has been observed by the writer from the Nye mudstone, the Yaquina formation, and the upper part of the Toledo formation. Records of this variety in California are largely from beds of Saucesian age (Kleinpell, 1938, p. 277).

Figured specimen (USNM 627001) from USGS locality f11869.

\section{Genus BIFARINA Parker and Jones, 1872}

Bifarina nuttalli Cushman and Siegfus

Plate 6, figure 3

Loxostomum applini Plummer. Nuttall, 1930, Jour. Paleontology, v. 4, no. 3, p. 285, pl. 24, figs. 4,5 .

Bifarina nuttalli Cushman and Siegfus, 1939, Cushman Lab. Foram. Research Contr., v. 15, pt, pt. 2, p. 28, pl. 6., fig. 6. Cushman and Siegfus, 1942, San Diego Soc. Nat. Hist., v. 9 , no, 34 , p. 413 , pl. 17 , fig. 4 .

Mallory, 1959, Lower Tertiary biostratigraphy of the California Coast Ranges: Am. Assoc. Petroleum Geologists, p. 204 , pl. 29 , fig. 2.

The specimens under consideration compare well with the type Bifarina nuttalli in that the general shape of the test is similar, the base of the chambers are crenulated, and there are longitudinal costae on the early part of the test. $B$. nuttalli has not been recorded previously from Washington, but it has been observed in Oregon in the Umpqua formation by the 
writer. This species is known in California from beds that are referred to Laiming's $\mathrm{C}$ zone and the lower part of his A-2 zone. Mallory $(1959$, p. 84,204$)$ indicated that $B$. nuttalli occurs in his Ulatisian stage and the lower part of his Narizian stage.

Figured specimen (USNM 627002) from USGS locality f11728.

\section{Genus UVIGERINA d'Orbigny, 1826}

Uvigerina churchi Cushman and Siegfus

Plate 6, figure 9

Uvigerina churchi Cushman and Siegfus, 1939, Cushman Lab. Foram. Research Contr., v. 15, pt. 2, p. 29, pl. 6, fig. 16. Mallory, 1959, Lower Tertiary biostratigraphy of the California Coast Ranges: Am. Assoc. Petroleum Geologists, p. 206, pl. 17, fig. 6 .

The irregular longitudinal costae broken between chambers and the blunt initial end are characteristic features of Uvigerina churchi that are well shown on the specimens from the northern Olympic Peninsula. This species occurs in more than half of the assemblages of the Aldwell formation and is questionably identified from several samples from the lower part of the Twin River formation. $U$. churchi has not been recorded previously from either Washington or Oregon but a similar form referred to as $U$. cf. $U$. yazooensis Cushman is recorded from the zone of the same name of southwestern Washington (Rau, 1958). The latter form differs from $U$. churchi in that the test is more elongate and the costae are higher and more distinct. In California, $U$. churchi is known from strata that are referred to Laiming's $A-2$ zone (Laiming, 1940), and Mallory (1959) showed the occurrence of this form in his Narizian stage.

Figured specimen (USNM 627003) from USGS locality f 11728.

\section{Uvigerina cocoaensis Cashman}

Plate 6, figure 5

Uvigerina cocoaensis Cushman, 1925, Cushman Lab. Foram. Research Contr., v. 1, pt. 3, p. 68, pl. 10, fig. 12.

Cushman and Schenck, 1928, California Univ. Dept. Geol. Sci. Bull., r. 17 , no. 9 , p. 312 , pl. 43 , figs. 17-19.

Cushman and Simonson, 1944, Jour. Paleontology, v. 18, no. 2 , p. 199 , pl. 33 , fig. 1 .

Cushman, 1946, Cushman Lab. Foram. Research, Spec. Pub. 16, p. 28, pl. 5, figs. 15-20.

Rau, 1951, Jour. Paleontology, v. 25, no. 4, p. 444, pl. 65, fig. 28.

Wilson, 1954, California, Univ. Pub. Geol. Sci., v. 30, no. 2 , p. 140 , pl. 16 , fig. 2 .

Smith, 1956, California Univ. Pub. Geol. Sci., จ. 32, no. 2, p. 96, pl. 12, fig. 11.
This well-known species occurs in the northern Olympic Peninsula only in strata of Refugian age. Because of its relatively frequent occurrence in the Twin River formation and because of its known restricted occurrence in rocks of the Refugian stage in other areas, it is a useful species for identifying rocks of Refugian age in the northern Olympic Peninsula. In southwest Washington Uvigerina cocoaensis is recorded from the Sigmomorphina schencki zone (Rau, 1958), and in Oregon it is known from the Bastendorff shale and the Keasey formation (Cushman and Schenck, 1928; Detling, 1946). Records of the species in California are from the Tumey formation (Cushman and Simonson, 1944), the Gaviota formation (Wilson, 1954), and the Wagonwheel formation (Smith, 1956). In all cases the containing beds have been regarded as Refugian in age.

Figured specimen (USNM 627004) from USGS locality f11862.

\section{Uvigerina gallowayi Cushman}

Plate 6, figure 7

Uvigerina gallowayi Cushman, 1929, Cushman Lab. Foram. Research Contr., v. 5, pt. 4, p. 94, pl. 13, figs. 33, 34.

Kleinpell, 1938, Miocene stratigraphy of California : Am. Assoc. Petroleum Geologists, p. 294, pl. 5, figs. 1, 2, 5.

Cushman and Simonson, 1944, Jour. Paleontology, v. 18, no. 2 , p. 200 , pl. 32, figs. 18,19 .

Rau, 1951, Jour. Paleontology, v. 25, no. 4, p. 444, pl. 65, fig. 24.

This species is restricted to a few samples from the upper part of the Twin River formation. Although uncommon in the area, its presence high in the local sequence is in accordance with previous records of Uvigerina gallowayi which are from beds of the Zemorrian stage only. In southwestern Washington it is known from beds that are assigned to the Zemorrian stage (Rau, 1958). There are no records of the species from Oregon but the writer has observed it in the Bastendorff shale. In California it is recorded from beds mapped largely as the Vaqueros formation or Temblor formation (Kleinpell, 1938, p. 294).

Figured specimen (USNM 627005) from USGS locality f11748.

\section{Uvigerina garzaensis Cushman and Siegfus Plate 6, figure 6}

Uvigerina garzaensis Cushman and Siegfus, 1939, Cushman Lab. Foram. Research Contr., v. 15, pt. 2, p. 28, pl. 6, fig. 15.

Cushman and Simonson, 1944, Jour Paleontology, v. 18, no. 2, p. 199, pl. 32, figs. 20, 21.

Detling, 1946, Jour. Paleontology, v. 20, no. 4, p. 357, pl. 50, fig. 8.

Rau, 1951, Jour. Paleontology, v. 25, no. 4, p. 445 , pl. 65 , fig. 19. 
This species is one of the more frequently occurring forms in the Tertiary sequence of the northern Olympic Peninsula. It is found throughout the Aldwell and Twin River formations. The shape and size of the test are noticeably varied but these variations are gradational and show no stratigraphic significance. Several described species probably are within the range of variance of the present specimens, but no stratigraphic usefulness is gained by dividing the group and therefore in this report they are all referred to one species, Uvigerina garzaensis. U. garzaensis has very little stratigraphic significance but its presence does suggest a general environment of cool water at substantial depths.

In California $U$. garzaensis is recorded largely from rocks of late Eocene age. It is known from the Coaledo and Bastendorff formations of Oregon (Detling, 1946) and has been observed by the writer in many other assemblages from Oregon of late Eocene age. It is recorded from southwestern Washington from rocks of the same age (Rau, 1958).

Figured specimen (USNM 627006) from USGS locality f11748.

\section{Genus ANGULOGerina Cushman, 1927}

\section{Angulogerina hannai Beck}

Plate 6, figure 11

Angulogerina hannai Beck, 1943, Jour. Paleontology, v. 17, no. 6, p. 607 , pl. 108 , figs. 26,28 .

Cushman, Stewart, and Stewart, 1947, Oregon Dept. Geology and Mineral Industries Bull. 36, pt. 5, p. 102, pl. pl. 12, fig. 16.

Specimens from the northern Olympic Peninsula compare in detail with Beck's description and illustration of Angulogerina hannai. Although individuals of this species are never found in abundance in any one sample, it occurs frequently in the rocks of Eocene age within the area, particularly in the lower part of the Twin River formation.

The species was originally described from the Cowlitz formation (Beck, 1943). It has since been recorded from the Bulimina schencki-Plectofrondicularia cf. $P$. jenkinsi zone of late Eocene age in southwest Washington (Rau, 1958) and from beds of late Eocene age in the Helmick Hills of western Oregon (Cushman, Stewart and Stewart, 1947).

Figured specimen (USNM 627007) from USGS locality f11886.

\author{
Family ROTALIDAE \\ Genus GYROIDINA d'Orbigny, 1826 \\ Gyroidina orbicularis planata Cushman \\ Plate 6, figure 10
}

Gyroidina orbicularis planata Cushman, 1935, U. S. Geol. Survey Prof. Paper 181, p. 45, pl. 18, flg. 3.

Cushman and Siegfus, 1942, San Diego Soc. Nat. History Trans., v. 9, p. 419, pl. 17, fig. 32.

Rau, 1951, Jour. Paleontology, v. 25, no. 4, p. 447, pl. 66, figs. 4-6.

Gyroidina orbicularis planata is common in much of the Tertiary sequence of the northern Olympic Peninsula. It occurs in several samples from the Aldwell formation, is well represented in most of the samples from the Twin River formation, and is present in one sample from the Clallam formation. Its long range makes it of little stratigraphic use. However, ecologically it is useful, because it suggests substantial depths in cool to cold water. $G$. orbicularis planata is recorded from rocks of late Eocene age and rocks that are referred to the Refugian and Zemorrian stages in southwestern Washington (Rau, 1958). Although not recorded from western Oregon, it has been observed by the writer from many parts of the Tertiary sequence there. In California, it is recorded from rocks of late Eocene age (Mallory, 1959).

Figured specimen (USNM 627008) from USGS locality f11749.

\section{Genus EPONIDES Montfort, 1808}

Eponides mansfieldi oregonensis Cushman, Stewart, and Stewart Plate 6, figure 12

Eponides mansfieldi Cushman. Cushman and Parker, 1931, Cushman Lab. Foram. Research Contr., v. 7, pt. 1, p. 12, pl. 2, fig. 10.

Eponides mansfieldi oregonensis Cushman, Stewart, and Stewart, 1947, Oregon State Dept. Geology and Mineral Industries Bull. 36, pt. 2, p. 48, pl. 6, fig. 4.

Rau, 1951, Jour. Paleontology, v. 25, no. 4, p. 447, pl. 66, figs. $14-16$.

The outstanding features of Eponides mansfieldi oregonensis are the papillate umbonal area on the ventral surface, the depressed sutures on the same surface, and the slightly scalloped periphery.

In the northern Olympic Peninsula its lowest occurrence is in the lower part of the Zemorrian stage but it occurs most frequently in the upper part of the Zemorrian stage. The known occurrence of this form in southwestern Washington is in the Pseudoglandulina aff. $P$. inflata and Epistominella parva zones, which are assigned to the Zemorrian and Saucesian stages, respec- 
tively (Rau, 1958). It is recorded from western Oregon from the Astoria formation (Cushman, Stewart, and Stewart, 1947) and has also been observed by the writer from the Nye mudstone, the Yaquina formation, and the upper part of the Toledo formation. Associated Foraminifera suggest that the Nye mudstone is Saucesian in age, whereas the Yaquina formation and the upper part of the Toledo formation are of Zemorrian age. The known occurrence of E. mansfieldi oregonensis is therefore in rocks no older than the Zemorrian age.

Figured specimen (USNM 627009) from USGS locality f11791.

\section{Genus CANCRIS Montfort, 1808}

Cancris joaquinensis Smith

Plate 6, figure 13

Cancris joaquinensis Smith, 19506, California Univ, Pub. Geol. Sci., จ. 32, no. 2, p. 98 , pl. 15, figs. 5, 6.

Specimens from the northern Olympic Peninsula compare in all respects with the illustrations and description of Cancris joaquinensis Smith. The species was originally described by Smith (1956) from the Wagonwheel formation of California, which he assigned to the Refugian stage. Smith indicated that the species also was observed from the Bastendorff and Keasey formations of Oregon. In the northern Olympic Peninsula area the highest occurrence of $C$. joaquinensis is in the Refugian stage, but its lowest occurrence in the area is in rocks of late Eocene age. This upper Eocene occurrence extends the lower range of the species, but its highest occurrence in the Refugian stage in northern Olympic Peninsula is useful for differentiating faunas of a pre-Zemorrian age from those of Zemorrian age.

Figured specimen (USNM 627010) from USGS locality f11862.

\section{Family AMPHISTEGINIDAE}

\section{Genus ASTERIGERINA d'0rbigny, 1839}

\section{Asterigerina crassiformis Cushman and Siegfus}

Plate 6, figure 14

Asterigerina crassiformis Cushman and Siegfus, 1935, Cushman Lab. Foram. Research Contr., v. 11, pt. 4, p. 94, pl. 14, fig. 10.

Cushman and Stone, 1949, Cushman Lab. Foram. Research Contr., r. 25, pt. 4, p. 82, pl. 14, fig. 16 .

Mallory, 1959, Lower Tertiary biostratigraphy of the California Coast Ranges: Am. Assoc. Petroleum Geologists, p. 242, pl. 37, fig. 13 .

This species makes its most frequent occurrence in the Aldwell formation but is also present in a few samples from the lower part of the Twin River formation. There are numerous records of this species from Cali- fornia (Mallory, 1959), all from rocks of middle and late Eocene age (Ulatisian and Narizian stages of Mallory). Cushman and Stone (1949) recorded it from the Verdun formation of Peru. Although there are no records of the species from Oregon, it has been observed by the writer in several samples from the Umpqua formation.

Figured specimen (USNM 627011) from USGS locality f11726.

\section{Genus AMPHISTEGINA d'Orbigny, 1826}

Amphistegina californica Cushman and M. A. Hanna

Plate 7, figure 6

Amphistegina californica Cushman and M. A. Hanna, 1927, San Diego Soc. Nat. History Trans., v. 5, no. 4, p. 56, pl. 6, figs. 3-5.

All specimens are from the Crescent formation and there they are the most common benthonic form known in the formation. Although they are all poorly preserved, a composite of the features that can be observed on various specimens constitutes Amphistegina californica as described by Cushman and Hanna (1927).

Amphistegina californica was originally described from sea cliffs near La Jolla, Calif. Mallory (1959) recorded the species only from his Ulatisian stage. There are no records of this species from either Oregon or Washington, but the writer has observed forms which may be species in the Umpqua formation of western Oregon and in rocks in southwestern Washington tentatively assigned to the Crescent formation by Pease and Hoover (1957).

Figured specimen (USNM 627012) from USGS locality f11720.

\section{Family CassiduLINIDaE}

Genus alabamina Toulmin, 1941

Alabamina kernensis Smith

Plate 7, figure 1

Alabamina kernensis Smith, 1956, California Univ. Pub. Geol. Sci., v. 32, no. 2, p. 99, pl. 15, figs. 3,4 .

Smith (1956) described this species from the Wagonwheel formation of California and also noted its occurrence in the Bastendorff shale of Oregon. The Refugian stage is represented in both of these formations. In the northern Olympic Peninsula Alabamina kernensis is found in rocks of Refugian and pre-Refugian ages in the Twin River formation and in the underlying Aldwell formation of Eocene age. These occurrences extend the records of $A$. kernensis into rocks of late Eocene age, but the Refugian stage remains the upper limit of its known occurrence. 
FORAMINIFERA, NORTHERN OLYMPIC PENINSULA, WASHINGTON

Figured specimen (USNM 627013) from USGS locality f11862.

Genus CASSIDULINA d'Orbigny, 1826

Cassidulina crassipunctata Cushman and Hobson

Plate 7, figure 3

Cassidulina crassipunctata Cushman and Hobson, 1935, Cushman Lab. Foram. Research, Contr., r. 11, pt. 3, p. 63, pl. 9, fig. 10.

Considerable variation in form is shown among individuals placed under this species, but they are within the limit of variation of the description of Cushman and Hobson (1935). Cassidulina crassipunctata is one of the more common species in rocks of Zemorrian age in the Twin River formation. Its lowest occurrence is useful for determining the base of the Zemorrian stage. This species has been tentatively referred to in southwestern Washington (Rau, 1958) where it also occurs in rocks of the Zemorrian stage.

The species was described from the type San Lorenzo formation of California (Cushman and Hobson, 1935) and has since been recorded in California from the Vaqueros and Temblor formations. All records of the species are from rocks of the Zemorrian stage.

Figured specimen (USNM 627014) from USGS locality f11796.

\section{Cassidulina globosa Hantken}

Plate 7, figure 4

Cassidulina glıbosa Hantken. 1875, Magyr. kir. földt. int. Evkön., r. 4 , p. 54 , pl. 16, fig. 2.

Beck, 1943, Jour. Paleontology, v. 17, no. 6, p. 609, pl. 108, figs. $7,13,14$.

Rau, 1951, Jour. Paleontology, v. 25, no. 4, p. 449, pl. 67, fig. 5 .

Smith, 1956, California, Lnir. Pub. Geol. Sci., v. 32, no. 2, p. 100 , pl. 14, fig. 2.

Mallors, 1959, Lower Tertiars biostratigraphy of the California Coast Ranges: Am. Assoc. Petroleum Geologists, p. 226, pl. 33, fig. 11 .

This species was found in the Aldwell formation and the lower part of the Twin River formation. It makes its highest occurrence in rocks of Refugian age, but it is more common in older rocks of late Eocene age.

Cassidulina globosa has a wide geographic distribution in rocks of late Eocene and early Oligocene age. It is recorded from Europe, Peru, Mexico, southeastem Inited States, California, Oregon, and Washington. The species is not found in large numbers in the northern Olympic Peninsula, but when present indicates a pre-Zemorrian age.

Figured specimen (USNM 627015) from USGS locality f11843.
Family CHILOSTOMELIIDAE

Genus CassidULINOIDES Cushman, 1927

Cassidulinoides sp.

Plate 7, figure 2

Test elongate, only slightly compressed, close coiled in early development, last few chambers tending to uncoil; chambers distinct, slightly inflated, last few increasing rapidly in size; sutures distinct, slightly depressed; walls smooth, finely perforate; aperture a broad slit approximately 45 degrees to the axis of greatest breadth at the terminal end.

Length, $0.31 \mathrm{~mm}$; breadth, $0.19 \mathrm{~mm}$; thickness, 0.16 $\mathrm{mm}$.

This form is known to occur only in the upper part of the Twin River formation or in those rocks assigned to the Zemorrian stage. There it appeared in a number of samples but was never common in any one sample.

Figured specimen (USNM 627016) from USGS locality $\mathrm{f} 11869$.

\section{Genus SPHAERoIDINA d'Orbigny, 1821}

Sphaeroidina variabilis Reuss

Plate 7, figure 7

Sphaeroidina variabilis Reuss, 1851, Zeitschr. deutsch geol. Ges., v. 3 , p. 88 , pl. 7 , figs. $61-64$.

Barbat and von Estorff, 1933, Jour. Paleontology, v. 7, no. 2, p. 173, pl. 23, fig. 19.

This species, although never abundant, is in an appreciable number of samples from the upper part of the Twin River formation. All specimens are from rocks assigned to the Zemorrian stage.

In southwest Washington it is also known from rocks of Zemorrian age (Rau, 1958) and in Oregon from the Istoria formation and Nye mudstone of Saucesian age. California records of the species are largely from rocks of the Zemorrian and Saucesian stages (Kleinpell, 1938). The many records of Sphaeroidina variabilis in Europe are from rocks of Oligocene and Miocene age. Within the northern Olympic Peninsula its presence indicates an age no older than that of the Zemorrian stage.

Figured specimen (USNM 627017) from USGS locality f11815.

Family GLOBIGERINIDAE

Genus Globigerina d'Orbigny, 1826

Globigerina cf. G. yeguaensis Weinzierl and Applin

Plate 7, figure 5

The genus Globigerina is represented by several forms in the Tertiary sequence of the northern Olympic 
Peninsula, but none are common. A form referred to as $G$. cf. $G$. yeguaensis is the only one that appears to be morphologically distinct and to be at least of local stratigraphic significance. This form is confined to rocks of Eocene age in the lower part of the Twin River formation and in the Aldwell formation. It is lobate, the three chambers of the last whorl increase rapidly in size, the walls are coarsely perforate, and the aperture has a lip.

Figured specimen (USNM 627018) from USGS locality f11729.

Family ANOMALINIDAE

Genus aNOMaLINa d'Orbigny, 1826

Anomalina californiensis Cushman and Hobson

Plate 7, figure 8

Anomalina californiensis Cushman and Hobson, 1935, Cushman Lab. Foram. Research Contr., v. 11, pt. 3, p. 64, pl. 9, fig. 8.

Smith, 1956, California Univ. Pub. Geol. Sci., v. 32, no. 2, p. 100 , pl. 16, fig. 3.

Considerable variation in form is observed in specimens that are referred to Anomalina californiensis. Some individuals are decidedly asymmetric, whereas others are nearly bilaterally symmetric and are difficult to differentiate from Nonion pompilioides. In most cases the test of $A$. californiensis is thinner than that of $N$.pompilioides.

In both the northern Olympic Peninsula and southwestern Washington the occurrence of $A$. californiensis is confined to the Refugian and Zemorrian stages. California records of this species are from rocks of the Refugian stage (Smith, 1956), Zemorrian stage, and lower part of the Saucesian stage (Kleinpell, 1938).

Figured specimen (USNM 627019) from USGS locality $\mathbf{f} 11876$.

\section{Genus CIBICIDEs Montfort, 1808 \\ Cibicides celebrus Bandy \\ Plate 7, fgure 10}

Cibicides celebrus Bandy, 1944, Jour. Paleontology, v. 18, no. 4, p. 374 , pl. 61 , fig. 8 .

Specimens occurring in the Crescent and Aldwell formations and the lower part of the Twin River formation compare in all details with the description and illustrations of Cibicides celebrus Bandy. This species is recorded from southwestern Washington from rocks of late Eocene age and of the overlying Refugian stage
(Rau, 1958). It was originally described from beds of Eocene age exposed at Cape Blanco, Oreg. (Bandy, 1944).

Figured specimen (USNM 627020) from USGS locality f11874.

Cibicides lobatus (d'Orbigny)

Plate 7, figure 9

Cibicides lobatus (d'Orbigny). Bandy, 1944, Jour. Paleontology, v. 18 , no. 4 , p. 374 , pl. 62 , fig. 1 .

Planoconvex, highly compressed specimens compare well with Bandy's description and illustrations of Cibicides lobatus (d'Orbigny) from beds of Eocene age at Cape Blanco, Oreg. In the northern Olympic Peninsula, C. lobatus occurs in beds of Eocene age in the lower part of the Twin River formation and in the Crescent formation.

Figured specimen (USNM 627021) from USGS locality f11882.

\section{Cibicides martinezensis malloryi Smith}

Plate 7, figure 11

Cibicides martinezensis malloryi Smith, 1957, California Univ.

Pub. Geol. Sci., v. 32, no. 3, p. 193, pl. 31, fig. 7.

The present specimens display high convexity of the ventral side and low convexity of the dorsal side; they have a coarsely perforate surface, and the early whorls are obscured on the dorsal side. These features are characteristic of Cibicides martinezensis malloryi. In the northern Olympic Peninsula this form makes one appearance in beds of Refugian age but all other occulrences are in rocks of late Eocene age in the lower part of the Twin River formation and the Aldwell formation. C. martinezensis malloryi was described from the Alhambra formation of California (Smith, 1957). Specimens similar to this form have also been observed by the writer from both the Umpqua and Tyee formations of Oregon.

Figured specimen (USNM 627022) from USGS locality f11799.

\section{ADDITIONAI IDENTIFIED SPECIES}

All species identified from the northern Olympic Peninsula but not illustrated in the report are listed in table 5, a reference is given for each species. An illustration and description of each listed species can be obtained from these references. 
TABLE 5.-Additional identified species from the northern Olympic Peninsula, Washington

Speciea

Vulvulina curta Cushman and Siegfus

Gaudryina cf. G. alazanensis Cushman

Karreriella cf. $K$. contorta Beck

Karreriella washingtonensis Rau.

Silicosigmoilina californica Cushman and Church

Quinquelooulina imperialis Hanna and Hanna.

cf. Q. triangularis d'Orbigny

Spiroloculina texanus Cushman and Ellisor

Sigmoilina tenuis (Ozjzek)

Triloculina cf. T. gilboei Beck

Robulus holcombensis Rau

cf. $\boldsymbol{R}$. pseudovortex Cole

cf. R. texanus (Cushman and Applin)

?Vaginulinopsis vacavillensis (G. D. Hanna)

Marginulina cf. M. subbullata Hantken

Dentalina cf. D. colei Cushman and Dusenbury

cf. $D$. consobrina d'Orbigny

dusenburyi Beck

cf. D. quadrulata Cushman and Laiming

sp. A [of Rau, 1948]

sp. C [of Rau, 1948]

sp. D [of Rau, 1948]

Nodosaria of. N. anomala Reuss

ef. $N$. hamilli Kleinpell

latejugata Gümbel

longistagata d'Orbigny

Pseudoglandulina cf. P. inflata (Bronemann)

Lagena conseripta Cushman and Barksdale

costata (Williamson)

heragona scalarifornis (Williamson)

substriata Williamson

sulcata (Walker and Jacob) -

Guttulina frankei Cushman and Ozawa

hantkeni Cushman and Ozawa

irregularis (d'Orbigny)

ef. G. pacifica (Cushman and Ozawa)

problema d'Orbigny

Pseudopolymorphina cf. P. ligua (Roemer)

Sigmomorphina pseudoschencki Rau.

Bolivinopsis directa (Cushman and Siegfus)

Plectofrondicularia cf. $P$. jenkinsi Church

Amphimorphina californica Cushman and McMaste:s

Nodogenerina cf. $N$. adolphina (d'Orbigny)

Bulimina alligata Cushman and Laiming

cf. $B$, bradburyi Martin

cf. B. ovata d'Orbigny

pupoides d'Orbigny

Globobulimina pacifica Cushman

Botivina cf. B. jacksonensis Cushman and Applin

Uvigerinella obsea impolata Cushman and Laiming

Siphonodosaria frizzelli Rau.

Ellipsonodosaria cf. E. cocoaensis (Cushman)

Discorbis aff. D. alveata stavensis Bandy

cf. D. humilis LeCalvez

$\nabla$ alvulineria cf. $V$. cooperensis Bandy

cf. V. depressa Cushman

aff. $V$. jacksonensis persimilis Bandy

cf. $V$. indiscriminata Mallory

menloensis Rau

tumeyensis Cushman and Simonson
Reference

Cushman and Siegfus, 1942, p. 401, pl. 15, figs. 7, 8 .

Rau, 1948a, p. 158, pl. 27, fig. $3,4$.

Beck, 1943, p. 592, pl. 98, figs. 4, 5.

Rau, 1948a, p. 158, pl. 27, figs. 5, 6.

Smith, 1957, p. 155, pl. 19, figs. 8,12 .

Beck, 1943, p. 592, pl. 98, figs. 9, 10.

Mallory, 1959, p. 130, pl. 36, figs. 5, pl. 39, fig. 5.

Rau, 1948a, p. 160, pl. 28, figs. 4, 5.

Rau, 1951, p. 430, pl. 63, fig. 2.

Beck, 1943, p. 594, pl. 101, figs. 1-3.

Rau, 1951, p. 431, pl. 63, figs. 14-17.

Smith, 1957, p. 158, pl. 20, figs. 12, 13 .

Rau, 1948a, p. 163, pl. 29, figs. 16, 17.

Mallory, 1959, p. 157, pl. 11, fig. 8, pl. 40, figs. 1, 7 .

Cushman and Siegfus, 1942, pl. 16, fig. 21.

Cushman and Dusenbury, 1934, p. 54, pl. 7, figs. 10-12.

Cushman and Dusenbury, 1934, p. 55, pl. 7, figs. 13-15.

Beck, 1943, p. 599, pl. 105, figs. 20, 23.

Cushman and Laiming, 1931, p. 99, pl. 10, fig. 13.

Rau, 1948 a, p. 166 , pl. 29 , fig. 3.

Rau, 1948a, p. 167, pl. 29, fig. 7.

Rau, 1948a, p. 167, pl. 29, fig. 8.

Cushman and Parker, 1931, p. 4, pl. 1, figs. 12-14.

Kleinpell, 1938, p. 218, pl. 4, figs. 4, 5.

Rau, 1956, p. 74, pl. 14. figs. 18-21.

Hedberg, 1937, p. 671, pl. 91, figs. $3,4$.

Rau, 1948a, p. 168, pl. 30, fig. 3.

Mallory, 1959, p. 175, pl. 14, fig. 4.

Mallory, 1959, p. 175, pl. 14, fig. 3 ; pl. 41, fig. 7.

Cushman and Laiming, 1931, p. 101, pl. 11, fig. 4.

Cushman and Laiming, 1931, p. 100, pl. 11, fig. 1.

Cushman and Parker, 1981, p. 6, pl. 1, fig. 20.

Rau, 1948a, p. 170, pl. 30, figs. 17, 18.

Rau, 1948a, p. 169, pl. 30, figs. 11, 12 .

Rau, 1948a, p. 169, pl. 30, figs. 7, 8 .

Cushman and Ozawa, 1930, p. 50, pl. 37, figs. 3-5.

Cushman and Ozawa, 1930. p. 19, pl. 2, figs. $1-6$; pl. 3 , fig. 1 .

Cushman and Ozawa, 1930, p. 89, pl. 22, figs. 5, 6.

Rau, 1951, p. 436, pl. 64, fig. 11.

Cushman and Siegfus, 1942, p. 409, pl. 16, figs. 27, 28.

Church, 1931, pl. A, figs. 5, 7-9.

Cushman and McMasters, 1936, p. 513, pl. 75, figs. 21-25.

Mallory, 1959, p. 216, pl. 41, fig. 10.

Cushman and Parker, 1947, p. 112, pl. 26, fig. 14.

Cushman and Parker, 1947, p. 96, pl. 30, fig. 9.

Cushman and Parker, 1947, p. 106, pl. 25, figs. 8, 9.

Cushman and Parker, 1947, p. 105, pl. 25, figs. 3-7.

Cushman and Parker, 1947, p. 134, pl. 29, fig. 37.

Cushman, 1937, p. 57, pl. 7, figs. 17, 18.

Cushman and Laiming, 1931, p. 111, pl. 12, fig. 11

Rau, 1948a, p. 171, pl. 30, fig. 10.

Beck, 1943, p. 608, pl. 108, fig. 10.

Bandy, 1949, p. 95, pl. 16, fig. 1.

LeCalvez, 1949, p. 24, pl. 3, figs. 48-50.

Bandy, 1944, p. 371, pl. 61, fig. 3.

Kleinpell, 1938, p. 311, pl. 9, fig. 22.

Bandy, 1949, p. 83, pl. 13, fig. 4.

Mallory, 1959, p. 230, pl. 20, fig. 2.

Rau, 1951, p. 446, pl. 66, figs. 17-22.

Cushman and Simonson, 1944, p. 201, pl. 33, figs. 13, 14. 
TABLE 5.-Additional identified species from the northern Olympic Peninsula, Washington-Continued

Valvulineria-Continued

Species willapaensis Rau

Gyroidina comdoni (Cushman and Schenck)

Eponides duprei ciervoensis Cushman and Simonson cf. E. ellisorae Garrett. umbonatus (Reuss) yeguaensis Weinzierl and Applin

Rotorbinella colliculus Bandy.

Epistomina eocenica (Cushman and Hanna)

Ceratobulimina washburni Cushman and Schenck

Allomorphina macrostoma Karrer

Chilostomella cf. C. oolina Schwager

Pullenia bulloides (d'Orbigny) ef. P. salisburyi R. E. and K. C. Stewart

anomalina packardi Bandy cf. A. regina Martin

Cibicides elmaensis Rau

haydoni (Cushman and Schenck) hodgei Cushman and Schenck horoelli Bandy. momastersi Beck cf. C. venezuelanus Nuttall

Discocyclina psila Woodring (Aktinocyclina) aster (Woodring)
Baggina teninoensis Rau.

Reference

Rau, 1951, p. 447, pl. 441, figs. 23-25.

Cushman and Schenck, 1928, p. 313, pl. 44, fig. 6, 7.

Cushman and Simonson, 1944, p. 201, pl. 34, figs. 2 , 3.

Cushman, Stewart, and Stewart, 1947, p. 79, pl. 10, fig. 7.

Rau, 1951, p. 448, pl. 66, figs. 1-3.

Beck, 1943, p. 608, figs. 1-4.

Bandy, 1944, p. 372, pl. 61, fig. 6.

Rau, 1948a, p. 172, pl. 31, figs. 1-3.

Rau, 1956, p. 76, pl. 15, figs. 24, 25.

Cushman and Schenck, 1928, p. 314, pl. 45, fig. 1.

Rau, 1948a, p. 173, pl. 31, figs. 4, 5.

Rau, 1951 , p. 450 , pl. 67 , fig. 8 .

Kleinpell, 1938, p. 338, pl. 5, figs. 10, 13.

Rau, 1951, p. 450, pl. 67, figs. 9, 10.

Bandy, 1944, p. 373, pl. 61, fig. 7.

Mallory, 1959, p. 261, pl. 38, fig. 6.

Rau, 1948a, p. 173, pl. 31, figs. 18-26.

Cushman and Schenck, 1928, p. 316, pl. 45, fig. 7.

Rau, 1951, p. 451, pl. 67, figs. 28-30.

Bandy, 1944, p. 374, pl. 61, fig. 9.

Beck, 1943, p. 612, pl. 109, figs. 2, 4, 15.

Mallory, 1959, p. 274, pl. 31, fig. 6.

Berthiaume, 1938, p. 496, pl. 61, figs. 8-11.

Berthiaume, 1938, p. 496, pl. 61, figs. 1-7.

TABLE 6.-Collecting localities-Continued

All foraminiferal collecting localities referred to in the report are listed in table 6. The formation from which each collection was made together with a public land description of each locality is also given.

TABLE 6-Collecting localities in the northern OHmpic Peninsula, Washington

[Public-land descriptions in reference to WHlamette meridian; measurements in feet]

\begin{tabular}{|c|c|}
\hline $\begin{array}{l}\text { U.S.G.S. } \\
\text { locality }\end{array}$ & Formation \\
\hline f11711... & Crescent.- \\
\hline $\begin{array}{l}111712 \ldots \\
\text { f11713... }\end{array}$ & \begin{tabular}{l}
....do.. \\
\hdashline... do
\end{tabular} \\
\hline t11714 _ & -_._do.. \\
\hline f11715... & ....do... \\
\hline f11716.. & _..-_do... \\
\hline f11717 . & -..-do..- \\
\hline f11718... & ....do... \\
\hline f11719... & - \\
\hline f11720.. & -...do do \\
\hline f11721 - - & -do...... \\
\hline f11722 & Aldwell. \\
\hline f11723 . . & .do..... \\
\hline fl1724 . - & -do.-. \\
\hline f11725 . & do... \\
\hline n1726.. & do..... \\
\hline f11727.. & do.... \\
\hline
\end{tabular}

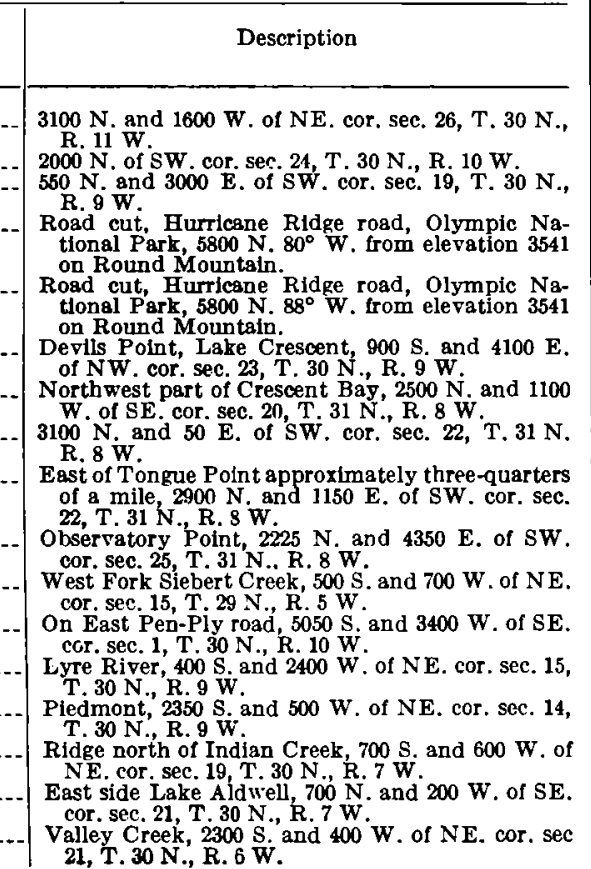

\begin{tabular}{|c|c|c|}
\hline $\begin{array}{l}\text { U.S.Q.S. } \\
\text { locality }\end{array}$ & Formation & Description \\
\hline f11728 & Aldwell_. & Valley Creek, $1800 \mathrm{~N}$, and $850 \mathrm{~W}$. of SE. cor. sec. \\
\hline f11729_. & ..do... & 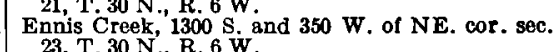 \\
\hline f11730 & -...do.. & Ennis Creek, $1500 \mathrm{~S}$. and $400 \mathrm{~W}$. of NE. cor. sec. \\
\hline f11731 & $\begin{array}{l}\text { Upper member of } \\
\text { Twin River. }\end{array}$ & $\begin{array}{l}\text { Pearson Creek, } 1100 \mathrm{~N} \text {. and } 2200 \text { E. of SW. cor. } \\
\text { sec. } 27, T .32 \text { N., R. } 12 \text { W. }\end{array}$ \\
\hline f11732. & $\begin{array}{l}\text { Lower member of } \\
\text { Twin River. }\end{array}$ & $\begin{array}{l}\text { Burnt Mountain Road, } 3150 \mathrm{~S} \text {. and } 950 \mathrm{E} \text {. of } \mathrm{NW} \text {. } \\
\text { cor. sec. 35, T. } 31 \mathrm{~N} \text {. K. } 12 \mathrm{~W} \text {. }\end{array}$ \\
\hline f11734 & ......do...... & $\begin{array}{l}\text { Burnt Mountain Rod, } 3600 \mathrm{~S} \text {. and } 1350 \mathrm{E} \text {. of } \mathrm{NW} \text {. } \\
\text { cor. sec. } 35 \text {. T. 31 N. R. } 12 \mathrm{~W} \text {. } \\
\text { Burnt Mountain Road, } 1400 \mathrm{~S} \text {. and } 400 \mathrm{E} \text {. of } \mathrm{NW} \text {. }\end{array}$ \\
\hline 111735 & $\begin{array}{l}\text { Middle member } \\
\text { of Twin River. }\end{array}$ & $\begin{array}{l}\text { cor. Sec. } 2, T .30 \mathrm{~N}, \mathrm{R} .12 \mathrm{~W} \\
\text { South Fork Pysht River, } 1500 \text { S. and } 2700 \text { E. of } \\
\text { NW. cor. sec. 19, T. } 31 \text { N., R. } 11 \text { W. }\end{array}$ \\
\hline f11736 & & $\begin{array}{l}\text { South Fork Pysht River, } 1900 \mathrm{~S} \text { a and } 2600 \mathrm{~W} \text {. of } \\
\text { NE. cor. sec. 19, T. } 31 \text { N., R. } 11 \text { W. }\end{array}$ \\
\hline f11737 _. & ..._do & $\begin{array}{l}\text { South Fork Pysht River, } 400 \mathrm{~S} \text {. and } 1800 \mathrm{~W} \text {. of } \\
\text { NE. cor. sec. } 19, \mathrm{~T} .31 \mathrm{~N} \text {., R. } 11 \text { W. }\end{array}$ \\
\hline f11738. & d & $\begin{array}{l}\text { South Frk Pysht River, a } 200 \text {, and } 1050 \text { W. of } \\
\text { NE. cor. sec. 19, T. } 31 \text {., R. } 11 \text { W. }\end{array}$ \\
\hline f11739. & do & $\begin{array}{l}\text { South Fork Pysht River, } 550 \text { N. and } 400 \mathrm{E} \text {. of SW. } \\
\text { cor. sec. } 20 \text {, T. } 31 \text { N., R. } 11 \text { W. }\end{array}$ \\
\hline n1740. & $\ldots$.............. & $\begin{array}{l}1850 \mathrm{~S}_{\mathrm{W}} \text { and } 1550 \mathrm{~W} \text {. of NE. cor. sec. } 31, \mathrm{~T} .31 \text { N., R. } \\
\text {. }\end{array}$ \\
\hline f11742. & $\begin{array}{l}\text { Lower member of } \\
\text { Twin River. }\end{array}$ & $\begin{array}{l}\text { Beaver Creek, } 800 \mathrm{E} \text {. of } \mathrm{NW} \text {. cor. sec. } 18, \mathrm{~T} .30 \mathrm{~N} \text {., } \\
\text { R.11 W. } \\
\text { Beaver Creek, } 1550 \mathrm{~S} \text {. and } 950 \mathrm{~W} \text {. of NE. cor. sec. }\end{array}$ \\
\hline \$11743 - & $\begin{array}{l}\text { Upper member of } \\
\text { Twin River. }\end{array}$ & $\begin{array}{l}\text { Approximately } 1 \text { mile west of Pillar Point, } 1200 \mathrm{~N} \text {. } \\
\text { and } 50 \mathrm{E} \text {. of } \mathrm{SW} \text {. cor, sec. 33, } \mathrm{T}, 32 \mathrm{~N}, \mathrm{R} \text {. }\end{array}$ \\
\hline f11744 & & $\begin{array}{l}\text { Approximately } 1 \text { mile west of Pillar Point, } 700 \mathrm{~N} \text {. } \\
\text { and } 400 \mathrm{E} \text {. of SW. cor. sec. } 33, \mathrm{~T}, 32 \mathrm{~N} \text {. R. } 11 \mathrm{~W} \text {. }\end{array}$ \\
\hline f11745. & -....do & $\begin{array}{l}\text { A pproximately } 1 \text { mile west of Pillar Point, 600 N. } \\
\text { and } 1000 \mathrm{E} \text {. of SW. cor. sec. } 33 \text {, T, } 32 \mathrm{~N} \text {. R. } 11 \mathrm{~W} \text {. }\end{array}$ \\
\hline f11746 & -...-. do.... & $\begin{array}{l}\text { Trihutary to Pysht River, } 1000 \mathrm{~N} \text {. and } 200 \mathrm{E} \text {. of } \\
\text { SW. cor. sec. } 16, \mathrm{~T}, 31 \mathrm{~N}, \mathrm{R} .11 \mathrm{~W}\end{array}$ \\
\hline f11747. & $\begin{array}{l}\text { Middle member } \\
\text { of Twin River. }\end{array}$ & $\begin{array}{l}\text { Middle Creek, } 1950 \mathrm{~S} \text {, gnd } 1700 \mathrm{E} \text {, of } \mathrm{NW} \text {. cor. sec. } \\
23, \mathrm{~T} \text {. } 31 \mathrm{~N} \text {. R. } 11 \mathrm{~W} \text {. }\end{array}$ \\
\hline f11748. & $\begin{array}{l}\text { Upper member of } \\
\text { Twin River. }\end{array}$ & $\begin{array}{l}\text { Pillar Point State Park on beach, } 2800 \mathrm{~N} \text {. and } 500 \\
\text { W. of SE. cor. sec. 10, T. } 31 \mathrm{~N} \text {., R. } 11 \mathrm{~W} \text {. }\end{array}$ \\
\hline f11749. & & $\begin{array}{l}\text { Pillar Point State Recreational area on heach. } 1400 \\
\text { N. and } 900 \mathrm{E} \text {. of SW. cor. sec. } 11, \mathrm{~T} .31 \mathrm{~N} \text {., } \mathrm{R} \text {. } \\
11 \mathrm{~W} \text {. }\end{array}$ \\
\hline f11751. & .......do......... & $\begin{array}{l}\text { Between Pillar Point and mouth of Jim Creek, } \\
\text { 1100 N. and } 16 \mathrm{CCO} \text { E. of SW. cor. sec. 11, T. 31 N., } \\
\text { R.11 W. } \\
\text { Approximately three-fourths mile northwest of } \\
\text { mouth of Jim Creek, E00 W. of NE. cor. sec. 14, } \\
\text { T. } 31 \text { N., R. } 11 \text { W. }\end{array}$ \\
\hline
\end{tabular}


FORAMINIFERA, NORTHERN OLYMPIC PENINSULA, WASHINGTON

TABLE 6.-Collecting localities-Continued

\begin{tabular}{|c|c|c|}
\hline $\begin{array}{l}\text { U.S.G.S. } \\
\text { locality }\end{array}$ & Formation & Description \\
\hline I11752. & UIper & $\operatorname{Jim}$ Creek, $550 \mathrm{~N}_{\mathrm{W}}$ and $100 \mathrm{E}$. of SW. cor. sec. 14 , \\
\hline f11753. & $\ldots$..... do & $\operatorname{Jim}$ Creek, $1000 \mathrm{~N}$. and $550 \mathrm{E}$. of SW. cor. sec. 13 , \\
\hline f11754. & $\begin{array}{l}\text { Middle member } \\
\text { of Twin River }\end{array}$ & Deep Creek, $2700 \mathrm{~N}$ and $1600 \mathrm{~W}$. of SE. cor. sec. 30 , \\
\hline$f 11756$ & & $\begin{array}{l}\text { 1)eep Creek } 2000 \mathrm{~N} \text {. nnd } 1600 \mathrm{~W} \text {. of St. cor. sec. } 30 \text {, } \\
\text { T. } 31 \text { N., R. } 10 \mathrm{~W} \text {. }\end{array}$ \\
\hline 111756 & ......do_ & Deep Creek, $1750 \mathrm{~N}$, and $2000 \mathrm{~W}$. of SE. cor. sec. \\
\hline f11767. & do & Deep Creek, $1000 \mathrm{~N}$. and $2000 \mathrm{~W}$. of SE. cor. sec. \\
\hline 111758. & ..... do. & $\begin{array}{l}\text { Deep Creek, } 600 \text { N. and } 2100 \text { W. of SE. cor. sec. } 30 \text {, } \\
\text { T. } 31 \text { N., R. } 10 \text { W. }\end{array}$ \\
\hline f11750 & do. & $\begin{array}{l}\text { Deep Creek, } 300 \mathrm{~N} \text {. and } 2100 \mathrm{~W} \text {. of SE. cor. sec. } 30 \text {, } \\
\text { T. } 31 \text { N., R. } 10 \text { W. }\end{array}$ \\
\hline f11760 & do & Deep Creek, $100 \mathrm{~N}$, and $2500 \mathrm{~W}$. of SE. cor. sec. 30 , \\
\hline f11761 & .do. & $\begin{array}{l}\text { Deep Creek, } 100 \text { s. and } 2350 \mathrm{E} \text {. of N W. cor. sec. } 31 \text {, } \\
\text { T. } 31 \text { N., R. } 10 \text { W. }\end{array}$ \\
\hline f11762 & .... do. & Deep Creek, $300 \mathrm{~S}$. and $1450 \mathrm{E}$. of $\mathrm{NW}$. cor. sec. 31 , \\
\hline f11763 & do & $\begin{array}{l}\text { Deep Creek, } 800 \mathrm{~S} \text {, and } 600 \mathrm{E} \text {. of NW. cor. sec. } 31 \text {, } \\
\text { T. } 31 \text { N., R. } 10 \text { W. }\end{array}$ \\
\hline f11764. & ._do_. & Deep Creek, $1950 \mathrm{~S}$, and $1200 \mathrm{~W}$. of NE. cor. sec. \\
\hline f11765 & do & Deep Creek, $1900 \mathrm{~S}$. and $2100 \mathrm{E}$. of NW. cor. sec. \\
\hline f11766 & ....do & $\begin{array}{l}\text { Deep Creek 1200, S. and } 400 \text { E. of NW. cor. sec. } \\
36, T, 31 \text { N., R. } 10 \text {. W. }\end{array}$ \\
\hline f11767. & ..do. & Deep Creek, $1900 \mathrm{~S}$. and $1800 \mathrm{~W}$. of NE. cor. sec. \\
\hline f11768 & -.. do & Deep Creek, $1200 \mathrm{~S}$. and $200 \mathrm{~W}$. of NE. cor. sec. \\
\hline$\{11769$. & do & $\begin{array}{l}\text { Deep Creek, } 800 \text { s. and } 400 \text { E. of NW. cor, sec. } \\
31, \text { T. } 31 \text { N., R. } 10 \text { W. }\end{array}$ \\
\hline f11770. & -do & $\begin{array}{l}\text { Deep Creek, } 1800 \mathrm{~S} \text {, and } 1200 \text { W. of NE. cor. sec. } \\
36, \text { T. } 31 \mathrm{~N} ., \text { R. } 11 \mathrm{~W} .\end{array}$ \\
\hline 111771 . & do & Deep Creek, $1900 \mathrm{~S}$, and $1000 \mathrm{~W}$. of NE. cor. sec. \\
\hline f11772. & do & $\begin{array}{l}\text { Deep Creek, } 2300 \mathrm{~S} \text { and } 900 \mathrm{~W} \text {. of NE. cor. sec. } 36 \text {, } \\
\text { T. } 31 \text { N., R. } 11 \text { W. }\end{array}$ \\
\hline f11773. & ._do. & $\begin{array}{l}\text { Deep Creek, } 2800 \text { S. and } 1050 \text { W. of NE. cor. sec. 36, } \\
\text { T. } 31 \text { N., R. } 11 \text {. }\end{array}$ \\
\hline $\begin{array}{l}\text { f11774, } \\
\text { f11775. } \\
\text { f11776... }\end{array}$ & & $\begin{array}{l}\text { Deep Creek, } 3000 \text {. and } 1100 \text { W. of NE. cor. sec. 36, } \\
\text { T. } 31 \text { N., R. } 11 \text { W. } \\
\text { Deen Creek, } 3100 \text {. and } 1100 \text { W. of NE. cor. sec. 36, }\end{array}$ \\
\hline f11777. & $\ldots$ do & T.ep Creek, $1700 \mathrm{~N}$. and $1000 \mathrm{~W}$. of SE. cor. sec. 36 , \\
\hline f11778. & 100 & Deep Creek, $1650 \mathrm{~N}$. and $1000 \mathrm{~W}$. of SE. cor. sec. 36, \\
\hline 111779 & do & Deep Creek $1600 \mathrm{~N}$. and $1000 \mathrm{~W}$. of SE. cor. sec. 36 , \\
\hline$\$ 11780$. & .do & Deep Creek, 1500 N. and 1000 W. of SE. cor. sec. 36, \\
\hline f11781. & & Deep Creck $1400 \mathrm{~N}$ and $1000 \mathrm{~W}$. of SE. cor. sec. 31 , \\
\hline f11782. & do & Deep Creek, $800 \mathrm{~N}$, and $1000 \mathrm{~W}$. of SE. cor. sec. 31 , \\
\hline f11783. & -d & Deep Creek, $700 \mathrm{~N}$ and $1000 \mathrm{~W}$. of SE. cor. sec. 31, \\
\hline f11784. & de & $\begin{array}{l}\text { Dcep Creek, } 650 \text { N. and } 100 \text { W. of SE. cor. sec. } 31 \text {, } \\
\text { T. } 31 \text { N. R. } 11 \text { W. }\end{array}$ \\
\hline f11785 & do & Deep Creek, $500 \mathrm{~N}, 1300 \mathrm{~W}$. of SE. cor. sec. 31 , \\
\hline f11786. & do & Deep Creek, $450 \mathrm{~N}$, and $1300 \mathrm{~W}$. of SE. cor. sec. 31, \\
\hline f11787. & $d 0$ & $\begin{array}{l}400 \mathrm{~N} \text {, and } 400 \mathrm{E} \text {, of SW, cor. sec. } 28, \mathrm{~T} .31 \mathrm{~N}, \mathrm{R} . \\
10 \mathrm{~W} \text {. }\end{array}$ \\
\hline f11788. & $\begin{array}{l}\text { Upper } m \\
\text { Twin I }\end{array}$ & $\begin{array}{l}\text { On coast, } 2 \text { miles west of West Twin R1ver, } 4500 \mathrm{~N}, \\
\text { and } 2700 \mathrm{~W} \text {. of } \mathrm{SF} \text {. cor. } \sec .21, T .31 \mathrm{~N} ., R .10 \mathrm{~W} \text {. }\end{array}$ \\
\hline f11789. & & $\begin{array}{l}\text { On coast, } 2 \text { miles west of West Twin River, } 3700 \mathrm{~N} \\
\text { and } 2400 \mathrm{~W} \text {. of SF. cor. sec. } 21 \text { T. } 31 \mathrm{~N} . \mathrm{R} .10 \mathrm{~W} \text {. }\end{array}$ \\
\hline f11790. & ido & On coast, 2 miles west of West Twin River, $3150 \mathrm{~N}$. \\
\hline f11791. & & $\begin{array}{l}\text { On coast, } 116 \text { miles west of West Twin River, } 2800 \\
\text { W. and } 400 \mathrm{E} \text {. of SW. cor sec. } 22, T .31 \text { N., R. } 10\end{array}$ \\
\hline f11792 - & & $\begin{array}{l}\text { On coast, half a mile west of West Twin River, } 2100 \\
\mathrm{~N} \text {. and } 200 \mathrm{E} \text {. of SW. cor, sec. } 23, \mathrm{~T} .31 \mathrm{~N}, \mathrm{R} \text {. } \\
10 \mathrm{~W} \text {. }\end{array}$ \\
\hline f11793. & & $\begin{array}{l}\text { On coast, } 500 \text { west of West Twin River, } 2450 \mathrm{~N} . \\
\text { and } 2700 \mathrm{E} \text {. of } \mathrm{SW} \text {. cor. sec. } 23, \mathrm{~T} .31 \mathrm{~N} ., \mathrm{R} .10 \mathrm{~W} \text {. }\end{array}$ \\
\hline f11794. & d & $\begin{array}{l}\text { On Twin River Road, } 1100 \mathrm{~S} \text { and } 550 \mathrm{~W} \text {. of NF. } \\
\text { cor. sec. } 26, \mathrm{~T}, 31 \mathrm{~N}, \mathrm{R}, 10 \mathrm{~W} \text {. }\end{array}$ \\
\hline f11795 & & On Twin River Road, $700 \mathrm{~N}$. and $250 \mathrm{E}$. of SW. cor. \\
\hline f11796. & & $\begin{array}{l}\text { On coast, a quarter of a mile east of East Twin } \\
\text { River, } 2100 \mathrm{~N} \text {. and } 1200 \mathrm{E} \text {. of } \mathrm{SW} \text {. cor, sec. } 24, \mathrm{~T} \text {. } \\
31 \mathrm{~N} \text {., R. } 10 \mathrm{~W} \text {. }\end{array}$ \\
\hline t11797. & do & $\begin{array}{l}\text { On coast, half a mile east of East Twin River, } 850 \\
\text { N. and } 2200 \mathrm{E} \text {. of SW. cor. sec. } 24, \mathrm{~T} .31 \mathrm{~N} \text {., R. } 10 \\
\text { W. }\end{array}$ \\
\hline f11798 & .....do & $\begin{array}{l}\text { On coast, three-quarters of a mile east of East Twin } \\
\text { River, } 800 \mathrm{~N} \text { and } 2500 \mathrm{E} \text {. of } \mathrm{SW} \text {. cor. sec. } 24, \mathrm{~T} \text {. } \\
31 \mathrm{~N}, \mathrm{R} .10 \mathrm{~W} \text {. }\end{array}$ \\
\hline f11798_ & $\begin{array}{l}\text { Lower member of } \\
\text { Twin River. }\end{array}$ & $\begin{array}{l}\text { On road on cast side of East Twin River, } 1300 \text { N. } \\
\text { and } 600 \text { W. of SE. cor sec. } 1, \text { T. } 30 \text { N., R. } 10 \text { W. }\end{array}$ \\
\hline
\end{tabular}

TABLE 6.-Collecting localities-Continued

\begin{tabular}{|c|c|c|}
\hline $\begin{array}{l}\text { U.S.C } \\
\text { local }\end{array}$ & For & Description \\
\hline 300 & $\begin{array}{l}\text { Upper } n \\
\text { Twin }\end{array}$ & $\begin{array}{l}\text { On coast, three-quar } \\
\text { River, } 800 \mathrm{~N} \text {. and } 3 \\
\text { N., R. } 10 \mathrm{~W} \text {. }\end{array}$ \\
\hline 1801 & ....do. & $\begin{array}{l}\text { ast Twin River, } 600 \mathrm{~N} \\
\text { s. } 19, \text { T. } 31 \text { N., R. } 9 \mathrm{~W} \text {. }\end{array}$ \\
\hline 1802 &.$- d c$ & 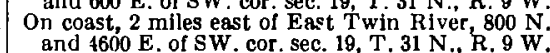 \\
\hline 1803 & ..do. & $\begin{array}{l}\text { On coast, } 21 / 4 \text { miles east of East Twin River, } 800 \\
\text { N. and } 6100 \text { E. of SW. cor. sec. } 19, T .31 \text { N., } R \text {. } \\
\theta \text { W. }\end{array}$ \\
\hline 1804 & . do & $\begin{array}{l}\text { On coest, } 21 / 4 \text { miles east of East Twin Rlver, } 550 \\
N \text { and } 6500 \mathrm{~F} \text {. of } \mathrm{SW} \text {. cor. Sec. } 19, \mathrm{~T} .31 \mathrm{~N} \text {., } \mathrm{R} \text {. } \\
9 \mathrm{~W} \text {. }\end{array}$ \\
\hline 1805. & .. do & $\begin{array}{l}\text { On coast. } 11 / 2 \text { miles west of } \mathrm{Mu} \\
\mathrm{N} \text {. and } 5400 \mathrm{~W} \text {. of } \mathrm{SW} \text {. cor. } \mathrm{sec} \\
\theta \mathrm{W} \text {. }\end{array}$ \\
\hline 1806 & - do & $\begin{array}{l}\text { On coast, } 11 / 4 \text { miles west of Murdock Creek, } 800 \\
\text { N. And } 4350 \mathrm{~W} \text {. of SE. cor. sec. } 19, \mathrm{~T} .31 \mathrm{~N}, \mathrm{R} \text {. } \\
9 \mathrm{~W} .\end{array}$ \\
\hline 1807. & . do & $\begin{array}{l}\text { On coast } 11 / 4 \mathrm{n} \\
\mathrm{N}_{\text {. and }} 3450 \\
9 \mathrm{~W} \text {. }\end{array}$ \\
\hline 1808 & . do & $\begin{array}{l}\text { On coast, } \\
\text { and } 180\end{array}$ \\
\hline 1800 & 0 & $\begin{array}{l}\text { On const, three- } \\
\text { Creek, 700 N. } \\
31 \text { N., R. } 9 \text { W. }\end{array}$ \\
\hline & $\mathrm{dr}$ & $\begin{array}{l}\text { On coast, ha] } \\
\text { N. and } 100\end{array}$ \\
\hline 011 & $-d$ & Murdock $C$ \\
\hline & -_do & Water we \\
\hline 1012 & $\mathrm{dc}$ & $\mathrm{N}$, and $1050 \mathrm{~W}$. of $\mathrm{SE}$. cor. sec. 28 , \\
\hline 181 & $\mathrm{dc}$ & $\begin{array}{l}\text { N. and } 800 \text { W. of SE. cor. sec. } 28 \text {, } \\
\text { W. }\end{array}$ \\
\hline 18 & ... do & $150 \mathrm{~N}$. and 750 W. of SE. cor. sec. 28 , \\
\hline 1018 & $-\mathrm{dc}$ & Lyre River, $650 \mathrm{~W}$, of SE. cor. sec. $28, \mathrm{~T} .31 \mathrm{~N}$. , \\
\hline 1817 & do & $50 \mathrm{~S}$. and $650 \mathrm{~W}$. of $\mathrm{N}$ \\
\hline 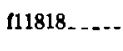 & $d n$ & Lyre River, $150 \mathrm{~S}$. and $650 \mathrm{~W}$. of NE. cor. sec. 33, \\
\hline חת & $d 0$ & Lyre River, $250 \mathrm{~S}$. and $650 \mathrm{~W}$. of NE. cor. sec. 33 , \\
\hline 190 & de & Lyre River, $350 \mathrm{~S}$, and $600 \mathrm{~W}$. of NE. cor. sec. 33, \\
\hline & & Lyre River, $450 \mathrm{~S}$, and $600 \mathrm{~W}$. of NE. cor. sec. 33, \\
\hline 1000 & dr & Lyre River, $600 \mathrm{~S}$, and $450 \mathrm{~W}$. of NE. cor. sec. 33 , \\
\hline 18 & do & Lyre River, $700 \mathrm{~S}$. and $350 \mathrm{~W}$. of NE. cor. sec. 33, \\
\hline & & Lyre River, $750 \mathrm{~S}$, and $200 \mathrm{~W}$. of NE. cor. sec. 33, \\
\hline 1008 & do & $\begin{array}{l}\text { Lyre River, } 1250 \mathrm{~S} \text {. of NE. cor. sec. } 33, \text { T. } 31 \text { N., } \\
\text { R. o W. }\end{array}$ \\
\hline & d & Lyre River, $1700 \mathrm{~S}$. and $300 \mathrm{E}$. of NW. cor. sec. 34, \\
\hline & d & $\begin{array}{l}\text { Lyre River, } 1750 \text { s. and } 400 \text { E. of NW. cor. sec. 34, } \\
\text { T. } 3 \text { i N., R. } 9 \text { W. }\end{array}$ \\
\hline & An & 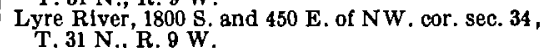 \\
\hline & & Lyre River, $2150 \mathrm{~S}$. and $400 \mathrm{E}$. of NW. cor. sec. 34 , \\
\hline & & $\begin{array}{l}\text { Lyre River, } 2500 \mathrm{~S} \text {. and } 500 \mathrm{E} \text {. of NW. cor. sec. } 34 \text {, } \\
\text { T. } 31 \text { N., R. } 9 \text { W. }\end{array}$ \\
\hline & do & 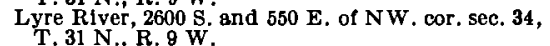 \\
\hline & $\begin{array}{r}\text { Middle } \\
\text { Twi } \\
- \text { do }\end{array}$ & $\begin{array}{l}\text { T.31 N., R. } 9 \text { W. } \\
\text { T. River, } 1900 \mathrm{~N} \text {. and } 850 \mathrm{E} \text {. of SW. cor. sec. } 34 \text {, } \\
\text { Lyre River, } 1850 \mathrm{~N} \text {, and } 850 \mathrm{E} \text {. of SW. cor. sec. } 34 \text {, }\end{array}$ \\
\hline & & and 800 E. of SW. cor. sec. 34 , \\
\hline & $d$ & 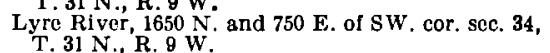 \\
\hline & & Lyre River, $1500 \mathrm{~N}$. and $650 \mathrm{E}$. of $\mathrm{SW}$. cor. sec. 34 , \\
\hline & & $\begin{array}{l}\text { Lyre River, } 1250 \mathrm{~N} \text {. and } 600 \mathrm{E} \text {. of } \mathrm{SW} \text {. cor. sec. } 34 \text {, } \\
\text { T. } 31 \mathrm{~N}, \mathrm{R}, 9 \mathrm{~W} \text {. }\end{array}$ \\
\hline & & $\begin{array}{l}\text { Lyre River, } 1050 \mathrm{~N} \text {. and } 550 \mathrm{E} \text {. of SW. cor. sec. } 34 \text {, } \\
\text { T. } 31 \mathrm{~N}, \mathrm{R}, 9 \mathrm{~W} \text {. }\end{array}$ \\
\hline & & 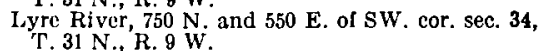 \\
\hline & & Lyre River, $700 \mathrm{~N}$. and $550 \mathrm{E}$. of SW. cor. sec. 34, \\
\hline & . & Lyre River, $350 \mathrm{~N}$. and $650 \mathrm{~F}$. of $\mathrm{SW}$. cor. sec. 34, \\
\hline & ... do & Lyre River, $250 \mathrm{~N}$. and $750 \mathrm{E}$. of SW. cor. sec. 34 , \\
\hline & & Lyre River, $100 \mathrm{~N}$ and $700 \mathrm{E}$. of SW. cor. sec. 34, \\
\hline & & Lyre River, $700 \mathrm{E}$. of $\mathrm{SW}$. cor. sec. $34, \mathrm{~T} .34 \mathrm{~N}$., \\
\hline & & $\begin{array}{l}150 \mathrm{~S} \text {, and } 750 \mathrm{E} \text {. of NW. cor. sec. } 3 \text {, } \\
\text { R. } 9 \mathrm{~W} \text {. }\end{array}$ \\
\hline
\end{tabular}


TABLE 6.-Collecting localities-Continued

\begin{tabular}{|c|c|c|}
\hline $\begin{array}{l}\text { U.S.G.S } \\
\text { locality }\end{array}$ & tion & ption \\
\hline & Iiddle $n$ & Lyre River, $300 \mathrm{~S}$, and $850 \mathrm{E}$. of $\mathrm{NW}$. cor. sec. 3 , \\
\hline 1847. & & Lyre River, $400 \mathrm{~S}$, and $900 \mathrm{E}$. of NW. cor. sec. 3 , \\
\hline f11848. & $\ldots d$ & Lyre River, $450 \mathrm{~S}$, and $1000 \mathrm{E}$. of NW. cor. sec. 3, \\
\hline 1849 & do & 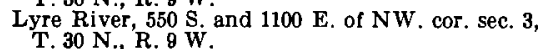 \\
\hline 11850 & ... do. & Lyre River, $600 \mathrm{~S}$, and $1150 \mathrm{E}$. of NW. cor. sec. 3 , \\
\hline 1851 & - $\mathrm{d}$ & Lyre River, $1200 \mathrm{~S}$. and $1250 \mathrm{E}$. of NW. cor, sec. 3, \\
\hline f11852. & .... do. & Lyre River, $1350 \mathrm{~S}$. and $1150 \mathrm{E}$. of NW. cor. sec. 3 , \\
\hline 111853 & . do & Lyre River, $1550 \mathrm{~S}$. and $1000 \mathrm{E}$. of NW. cor. sec. 3 , \\
\hline 511854 & $-\ldots . .$. do & Lyre River, $1600 \mathrm{~S}$. and $950 \mathrm{E}$. of NW. cor. sec. 3 , \\
\hline f11855 & $\begin{array}{l}\text { Lower member of } \\
\text { Twin River. }\end{array}$ & Lyre River, $700 \mathrm{~N}$. and $1000 \mathrm{E}$. of $\mathrm{SW}$. cor. sec. 3 , \\
\hline f11856. & ...... do & Lyre River, $600 \mathrm{~N}$, and $1100 \mathrm{E}$. of SW. cor. sec. 3 , \\
\hline f11857 & . do & Lyre River, $400 \mathrm{~N}$, and $1200 \mathrm{E}$. of SW. cor. sec. 3 , \\
\hline 11858. & _. _do & Lyre River, $100 \mathrm{~N}$, and $1450 \mathrm{E}$. of SW. cor. sec. 3 , \\
\hline f11859 & ... do.... & Lyre River, $1100 \mathrm{~S}$. and $1600 \mathrm{E}$. of NW. cor. sec. 10 , \\
\hline $\mathbf{1 1 8 6 0}$ & $\begin{array}{l}\text { Upper member of } \\
\text { Twin River. }\end{array}$ & $\begin{array}{l}\text { On coast, half a mile east of Gettysburg Ranch, } 250 \\
\text { S. and } 2750 \text { E. of NW. cor. sec. } 27, T \text {. } 31 \mathrm{~N} ., \mathrm{R} \text {. } \\
9 \mathrm{~W} \text {. }\end{array}$ \\
\hline f11861 & $\begin{array}{l}\text { Middle member } \\
\text { of Twin River. }\end{array}$ & $\begin{array}{l}\text { On coast, a quarter of a mile east of Field Creek, } 800 \\
\text { S. and } 700 \mathrm{~W} \text {. of } \mathrm{NE} \text {. cor. sec. } 27, \mathrm{~T} .31 \mathrm{~N} ., \mathrm{R} .9 \mathrm{~W} .\end{array}$ \\
\hline 1862 & & On coast, half a mile east of Field Creck, $600 \mathrm{~S}$. and \\
\hline f11863 & -.... do. & On coast, 1 mile west of Whisky Creek, $500 \mathrm{~S}$. and \\
\hline f11864 & & N. and \\
\hline 111865 & $\begin{array}{l}\text { Middle m } \\
\text { of Twin }\end{array}$ & $\begin{array}{l}\text { Salt Creek vallev, } 1400 \mathrm{~S} \text {. and } \\
\text { sec. } 34, T, 31 \mathrm{~N}, \mathrm{R}, 8 \mathrm{~W} \text {. }\end{array}$ \\
\hline$\{11866$ & 01 in & $\begin{array}{l}\text { Salt Creok valley, } 400 \mathrm{~s} \text {. and } 500 \mathrm{E} \text {. of NW. cor. sec. } \\
35, \mathrm{~T} .31 \mathrm{~N} . \text { R. } 8 \mathrm{~W} \text {. }\end{array}$ \\
\hline 611867 & $\begin{array}{l}\text { Upper member of } \\
\text { Twin River. }\end{array}$ & $\begin{array}{l}\text { Freshwater Bay, } 3300 \mathrm{~N} \text { and } 1100 \mathrm{~W} \text {. of NE. cor. } \\
\text { sec. } 31, \text { T. } 31 \text { N., R, } 7 \text { W. }\end{array}$ \\
\hline f11868 & & $\begin{array}{l}\text { Coville Creck, } 400 \mathrm{~N} \text {. and } 350 \mathrm{~W} \text {. of SE. cor. sec. } 31 \text {, } \\
\text { T. } 31 \text { N. R. } 7 \mathrm{~W} \text {. }\end{array}$ \\
\hline 1869 & ... do & $\begin{array}{l}\text { Freshwater Bay, } 3000 \mathrm{~N} \text { and } 1500 \mathrm{E} \text {. of } \mathrm{SW} \text {. cor. } \\
\text { sec. } 32, \mathrm{~T} \text {. } 31 \mathrm{~N}, \mathrm{R} .7 \mathrm{~W} \text {. }\end{array}$ \\
\hline & . - do & $\begin{array}{l}\text { Fresh water } 13 a y, 2400 \mathrm{~N} \text { and } 1400 \mathrm{~W} \text {. of SE. cor. } \\
\text { sec. } 32, \text { T. } 31 \text { N., R. } 7 \mathrm{~W} \text {. }\end{array}$ \\
\hline f11871. & ...do. & $\begin{array}{l}2100 \mathrm{~N} \text {. and } 150 \mathrm{E} \text {. of } \mathrm{SW} \text {. cor. sec. } 33, \mathrm{~T} .31 \mathrm{~N} ., \mathrm{R} . \\
\text {. }\end{array}$ \\
\hline 187 & $\begin{array}{l}\text { Lower } \\
\text { Twin }\end{array}$ & $\begin{array}{l}\text { Eden Valley, } 1200 \mathrm{~N} \text {, and } 1200 \mathrm{~W} \text {. of SE. cor. sec. } \\
7, \text { T. } 30 \mathrm{~N}, \mathrm{R}_{\mathrm{W}} 7 \mathrm{~W} \text {. }\end{array}$ \\
\hline f11873. & & Ridge south of Eden valley, $1400 \mathrm{~S}$, and $2300 \mathrm{E}$. of \\
\hline$\lceil 11874$ & 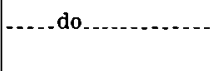 & $\begin{array}{l}\text { On Elwha River north of Olympic Power Plant } \\
\text { Dam, } 2000 \mathrm{~S} \text {. and } 2000 \text { W. of NE. cor. sec. 15, T. } \\
30 \mathrm{~N} \text {., R. 7. W. }\end{array}$ \\
\hline $\mathbf{f} 11875$ & Middle & $\begin{array}{l}\text { Tumwater Creek, } 1200 \mathrm{~S} \text {. and } 200 \mathrm{~W} \text {. of NE. cor. } \\
\text { sec. } 17, \mathrm{~T} .30 \mathrm{~N}, \mathrm{R}, 6 \mathrm{~W} \text {. }\end{array}$ \\
\hline 1876 & & $\begin{array}{l}\text { Tumwater Creek, } 1900 \mathrm{~S} \text {. and } 450 \mathrm{~W} \text {. of NE. cor } \\
\text { sec. } 17, \text { T. } 30 \mathrm{~N}, \mathrm{R}, 6 \mathrm{~W}\end{array}$ \\
\hline f11877. & .....do & Ennis Creek, $600 \mathrm{~S}$ and $300 \mathrm{~W}$. of NE. cor. se \\
\hline 1878 & & Ennis Creek, $1400 \mathrm{~S}$, and $2800 \mathrm{~W}$, of $\mathrm{N} E$ cor. $\mathrm{sec}$ \\
\hline 187 & & Ennis Creek, $550 \mathrm{~S}$. and $2600 \mathrm{~W}$. of NE. co \\
\hline & $\ldots$ do & Lees Creek, $650 \mathrm{~N}$. and $450 \mathrm{~W}$. of SE. cor. sec. 12 , \\
\hline 11881 & & Iorse Creek, $800 \mathrm{~S}$. and $1100 \mathrm{E}$. of NW. cor. sec. \\
\hline & & Bagley \\
\hline & Lowor ${ }^{\prime}$ & Bagley Creek, $1100 \mathrm{~S}$. and $1100 \mathrm{E}$. \\
\hline 1884 & & S. and $800 \mathrm{E}$. of NE. \\
\hline 111885 & $\begin{array}{l}\text { Middle I } \\
\text { of Twi }\end{array}$ & $\begin{array}{l}\text { cor. Fork Siebert Creek, 2150 S. and } 200 \mathrm{E} \text {. of } \\
\text { NW. cor. sec. 11, T. } 29 \mathrm{~N}, \mathrm{R} .5 \mathrm{~W} \text {. } \\
\text { Siebert Creek, } 1600 \mathrm{~S} \text {. and } 900 \mathrm{E} \text {. of NW. cor. sec. }\end{array}$ \\
\hline 11887 & & bert Creek tributary, 1150 \\
\hline & & eek, $1100 \mathrm{~W}$, of $\mathrm{NE}$. \\
\hline $\begin{array}{l}f 11889 \\
f 11890\end{array}$ & $\begin{array}{l}\text { Upper member of } \\
\text { Twin River. }\end{array}$ & $\begin{array}{l}1700 \mathrm{~S} \text {. and } 1150 \mathrm{~W} \text {. of NE. cor. see. } 15, \mathrm{~T} .30 \mathrm{~N} \text {, } \\
\text { R. } 5 \text { W. } \\
\text { Siebert Creck, } 650 \mathrm{~S} \text {. of NW. cor. sec. } 13, \text { T. } 30\end{array}$ \\
\hline 11891. & Clallam. & and $2000 \mathrm{E}$. of SW. cor. sec \\
\hline & & Pearson Creek, $1200 \mathrm{~N}$ and $1100 \mathrm{E}$. of SW. cor. sec. \\
\hline & & $\begin{array}{l}\text { On coast, } 1 \text { mile west of Pillar Point, } 300 \mathrm{~N} \text {. and } 1750 \\
\text { W. of SE. cor. sec. } 33, T .32 \text { N., R. } 12 \text { W. }\end{array}$ \\
\hline
\end{tabular}

\section{REFERENCES CITED}

Bandy, O. L., 1944, Eocene Foraminifera from Cape Blanco, Oregon: Jour. Paleontology, v. 18, no. 4, p. 366-377, 3 pls. 1949, Eocene and Oligocene Foraminifera from Little Stave Creek, Clarke County, Alabama: Am. Paleontology Bull., จ. 32, no. 131, 210 p., 27 pls.

1953, The frequency distribution of Recent Foraminifera of California, pt. 1 of Ecology and paleoecology of some California Foraminifera: Jour. Paleontology, v. 27, no. 2, p. 161-182, pls. 21-25.

Barbat, W. F., and von Estorff, F. E., 1933, Lower Miocene Foraminifera from the southern San Joaquin Valley, California: Jour. Paleontology, v. 7, no. 2, p. 164-174, pl. 23.

Beck, R. S., 1943, Eocene Foraminifera from Cowlitz River, Lewis County, Washington: Jour. Paleontology, v. 17, no. 6, p. 584-614, pls. 98-109.

Berthiaume, S. A., 1938, Orbitoids from the Crescent formation (Eocene) of Washington: Jour. Paleontology, v. 12, no. 5, p. 494-497, 1 pl.

Brown, R. D., Jr., and Gower, H. D., 1958, Twin River formation (redefinition), northern Olympic Peninsula, Washing ton: Am. Assoc. Petroleum Geologists Bull., v. 42, no..10, p. 2492-2512.

Brown, R. D., Jr., Gower, H. D., and Snavely, P. D., Jr., 1960, Geology of the Port Angeles-Lake Crescent area, Clallam County, Washington: U.S. Geol. Survey Oil and Gas Inv. Map OM-203.

Brown, R. D., Jr., Snavely, P. D., Jr., and Gower, H. D., 1956, Lyre formation (redefinition), northern Olympic Peninsula, Washington: Am. Assoc. Petroleum Geologists Bull., v. 40, no. 1, p. 94-107.

Church, C. C., 1981, Foraminifera of the Kreyenhagen shale, in Chap. 2, Mining in California : California Jour. Mines and Geology 27th Rept. State Mineralogist, p. 202-213, pls. A-C. 1943, Descriptions of Foraminifera in Part 2 of Geologic formations and economic development of the oil and gas flelds of California : California Div. Mines Bull. 118, p. 182.

Crouch, R. W., 1952, Significance of temperature on Foraminifera from deep basins off southern California coast: Am Assoc. Petroleum Geologists Bull., v. 36, no. 5, p. 807-843.

Cushman, J. A., 1927, Recent Foraminifera from off the west coast of America: Scripps Inst. Oceanography Bull., Tech. Ser., v. 1, no. 10, p. 119-188, 6 pls.

-1937, A monograph of the subfamily Virgulininea of the foraminiferal family Buliminidae: Cushman Lab. Foram. Research Contr., Spec. Pub. 9, 228 p., 24 pls.

1939, A monograph of the foraminiferal family Nonionidae: U.S. Geol. Survey Prof. Paper 191, 100 p.

1950, Foraminifera : their classification and economic use, 4th ed.: Cambridge, Mass., Harvard Unir. Press, 605 p.

Cushman, J. A., and Dusenbury, A. N., Jr., 1934, Eocene Foraminifera of the Poway conglomerate of California: Cushman Lab. Foram. Research Contr., v. 10, pt. 3, p. 51-65, pls. 7-9.

Cushman, J. A., and Hanna, M. A., 1927, Foraminifera from the Eocene near San Diego, California: San Diego Soc. Nat. History Trans., v. 5, no. 4, p. 45-64, pls. 4-6.

Cushman, J. A., and Hobson, H. D. 1935, A foraminiferal faunule from the type San Lorenzo formation, Santa Cruz County, California : Cushman Lab. Foram. Research Contr., v. 11 , pt. 3, p. 53-64, pls. 8,9

Cushman, J. A., and Laiming, Boris, 1931, Miocene Foraminifera from Las Sauces Creek, Ventura County, California: Jour. Paleontology, v. 5, no. 2, p. 79-120, pls. 9-14. 
Cushman, J. A., and McMasters, J. H., 1936, Middle Eocene Foraminifera from the Llajas formation, Ventura County, California : Jour. Paleontology, v. 10, no. 6, p. 497-517, pls. 74-77.

Cushman, J. A., and Ozawa, Yoshiaki, 1930, A monograph of the foraminiferal family Polymorphinidae recent and fossil : U.S. Museum Proc., v. 77, art. 6, 185 p., 40 pls.

Cushman, J. A., and Parker, F. L., 1931, Miocene Foraminifera from the Temblor of the east side of the San Joaquin Valley, California: Cushman Lab. Foram. Research Contr., v. 7, pt. 1, 16 p., 2 pls.

1947, Bulimina and related foraminiferal genera: U.S. Geol. Survey Prof. Paper 210-D, p. 55-176, pls. 15-30.

Cushman, J. A., and Schenck, H. G., 1928, Two foraminiferal faunules from the Oregon Tertiary : California Univ., Dept. Geol. Sci. Bull., v. 17, no. 9, p. 305-324, pls. 42-45.

Cushman, J. A., and Siegfus, S.S., 1935, New species of Foraminifera from the Kreyenhagen shale of Fresno County, California : Cushman Lab. Foram. Research Contr., v. 11, pt. 4, p. $90-95$, pl. 14.

- 1942, Foraminifera from the type area of the Kreyenhagen shale of California: San Diego Soc. Nat. History Trans., v. 9 , no. 34 , p. $385-426$, pls. $14-19$.

Cushman, J. A., and Simonson, R. R., 1944, Foraminifera from the Tumey formation, Fresno County, California : Jour. Paleontology, v. 18, no. 2, p. 186-203, pls. 30-34.

Cushman, J. A., Stewart, R. E., and Stewart, K. C., 1947, Five papers on Foraminifera from the Tertiary of western Oregon: Oregon Dent. Geology and Mineral Industries Bull. 36, pts. 1-5, 111 p., 13 pls.

1949, Upper Eocene Foraminifera from the Toledo formation, Toledo, Lincoln County, Oregon : Oregon Dept. Geology and Mineral Industries Bull. 36, pt. 6, p. 126-144, pls. 14-16.

Cushman, J. A., and Stone, Benton, 1949, Foraminifera from the Eocene Verdun formation of Peru: Cushman Lab. Foram. Research Contr., v. 26, pt. 4, p. 73-83, pls. 13, 14.

Detling, M. R., 1946, Foraminifera of the Coos Bay lower Tertiary, Coos County, Oregon: Jour. Paloentology, v. 20, no. 4, p. $348-361$, pls. $46-51$.

Glaessner, M. F., 1947, Principles of micropaleontology : New York, John Wiley and Sons, Inc., 296 p.

Gower, H. D., 1960, Geology of the Pysht quadrangle, Washington : U. S. Geol. Survey Geol. Quad. Map GO-129.

Hedberg, H. D., 1937, Foraminifera of the middle Tertiary Carapita formation of northeastern Venezuela: Jour. Paleontology, v. 11, no. 8, p. 661-697, pls. 90-92.

Kleinpell, R. M., 1938, Miocene stratigraphy of California: Am. Assoc. Petroleum Geologists, 450 p., 14 figs., 22 pls., 18 tables.

Laiming, Boris, 1940, Some foraminiferal correlations in the Eocene, of San Joaquin Valley, California: Sixth Pacific Sci. Cong. Proc., v. 2, p. 535-568, 9 figs.

LeCalvez, Y., 1949, Rotaliidae et familles affines [pt. 2] of Révision des foraminfères lutéiens dụ Bassin de Paris: France Service Carte Geol. Mem., 54 p., 6 pls.

Mallory, V. S., 1953, some lower Eocene correlations of the Pacific Coast [abs.] : Geol. Soc. America Bull,, v. 64, no. 12 , pt. 2, p. 1520.

1959, Lower Tertiary biostratigraphy of the California Coast Ranges: Am. Assoc. Petroleum Geologists, 416 p., 42 pls.
Natland, M. L., 1933, the temperature- and depth-distribution of some Recent and fossil Foraminifera in the southern California region: Scripps Inst. Oceanography Bull., Tech. Ser., v. 3, no. 10 , p. 225-230.

Norton, R. D., 1930, Ecologic relations of some Foraminifera: Scripps Inst. Oceanography Bull., Tech. Ser., v. 2, no. 9, p. 331-388.

Pardee, J. T., 1921, Deposits of manganese ore in Montana, Utah, Oregon, and Washington: U.S. Geol. Survey Bull. 725-C, p. 141-243.

Park, C. F., Jr., 1946, The spilite and manganese problems of the Olympic Peninsula, Washington: Am. Jour. Sci., v. 244, no. 5, p. 305-323, 5 figs.

Parker, F. L., 1948, Foraminifera of the Continental Shelf from the Gulf of Maine to Maryland: Harvard Coll. Mus. Comp. Zoology Bull., v. 100, no. 2, p. 214-241, 7 pls.

Pease, M. H., and Hoover, Linn, 1957, Geology of the Doty-Minot Peak area, Washington: U.S. Geol. Survey Oil and Gas Inv. Map OM-188.

Phleger, F. B., and Parker, F. L., 1951, Ecology of Foraminifera, northwest Gulf of Mexico: Geol. Soc. America Mem. 46, pt. 1, 88 p.; pt. 2,64 p. ; 20 pls.

Rau, W. W., 1948a, Foraminifera from the Porter shale (Lincoln formation), Grays Harbor County, Washington: Jour. Paleontology, v. 22, no. 2, p. 152-174, pls. 27-31.

$1948 b$, Foraminifera from the Miocene Astoria formation in southwestern Washington: Jour. Paleontology, v. 22 no. 6 , p. 774-782, pl. 119 .

1951, Tertiary Foraminifera from the Willipa River valley of southwest Washington: Jour. Paleontology, v. 25, no. 4, p. 417-453, pls. 63-67.

- 1956, Foraminifera from the McIntosh formation (Eocene) at McIntosh Lake, Washington: Cushman Found. Foram. Research Contr., v. 7, pt. 3, p. 69-78, pls. 14, 15 .

19.58, Stratigraphy and foraminiferal zonation in some of the Tertiary rocks of southwestern Washington: U.S. Geol. Survey Oil and Gas Inv. Chart $\mathrm{OC}-57,2$ sheets.

Reagan, A. B., 1909, Some notes on the Olympic Peninsula, Washington: Kans, Acad. Sci. Trans., v. 22, p. 131-238.

Schenck, H. G., and Kleinpell, R. M., 1936, Refugian stage of Pacifle Coast Tertiary: Am. Assoc. Petroleum Geologists Bull., v. 20, no. 2, p. 215-225.

Smith, B. Y., 1957, Lower Tertiary Foraminifera from Contra Costa County, California : California Univ. Pubs. Geol. Sci., v. 32 , no. 3 , p. 127-242, pls. 17-32.

Smith, H. P., 1956, Foraminifera from the Wagonwheel formation, Devils Den district, California : California Univ. Pubs. Geol. Scie., v. 32, no. 2, p. 65-126, pls. 9-16.

Snavely, P. D., Jr., Brown, R. D., Jr., Roberts, A. E., and Rau, W. W., 1958, Geology and coal resources of the CentraliaChehalis district, Washington: U.S. Geol. Survey Bull. 1053, $159 \mathrm{p}$.

Vaughan, T. W., 1945, American Paleocene and Eocene larger Foraminifera: Geol. Soc. America Mem. 9, pt. 1, 175 p., $46 \mathrm{pl}$.

Weaver, C. E., 1912, A preliminary report on the Tertiary paleontology of western Washington: Geol. Survey Bull. 15, $80 \mathrm{p}$.

Weaver, C. E., and others, 1944, Correlation of the Marine Cenozoic formations of western North America: Geol. Soc. America Bull., v. 55, p. 569-598.

Wilson, E. J., 1954, Foraminifera from the Gaviota formation east of Gaviota Creek, California : California Univ. Pubs. Geol. Sci., v. 30, no. 2, p. 103-170, pls. 12-18. 



\section{INDEX}

[Where several page rumbers appear, major references are in italic]

\section{A Page}

Acknowledgments............................ 1 adelaidana, Bolivina marginata............ 8, $9,11,19$ adolphina, Nodogenerina. .................... 25 advena, Bolivina. ..................... 8, 13,18 (Aktinocyclina) aster, Discocyclina............... Alabamina.................................. 22 kernensis . ......................... 4, 8, 11,22 alazanensis, Gaudryina........................ 7, 25 Aldwell formation, Foraminlfera..............- 4 , $15,17,18,20,21,22,24$ paleoecology stratlgraphy..................... Alhambra formation....................... 6, 10, 24 allioata, Bulimina alsatica, Bulimina .......................... 7,9,11, 18 alveata stavensis, Discorbis_.................. 3,25 A mphimorphina californica..................... 4,5, 25 Amphistegina ............................... 22 californica. _.......................... 3, 4, 22

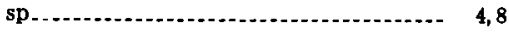
Amphisteginidae............................... $\quad 22$ Angulogerina............................... 21 hannai........................... 4, 6,8,11,21 anomala, Nodosaria.......................... 7, 25 Anomalina............................... 24 californiensis.......................... 8,11, 13, 24 packardi_.............................. 3,26 regina

Anomallnldar ........................... 24 applini, Loxostomum aster, Discocyclina............................ $\quad 26$ Discocyclina (Aktinocyclina) Asterigerina................................... crassiformis....................... 4, $8,10,11,22$

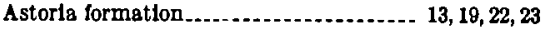

\section{B}

Bagoina teninoensis 17,20,21,22 Benthonic assemblages, Crescent formation.-. 3 Bifarina... nuttalli.

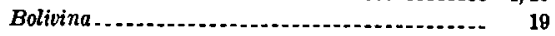
advena_._. jacksonensis............................. 8, 25 marginata adelaidana.................. 8,9,11, 19 Bolivinopsis directa.................... 4, 7,25 boueane, Nonionella........................... 16

Oradburyi, Bulimina. ..................... 4,25

Bulimina alligata. . . . alsa!ica.............................. 7,9,11, 18 bradburyi. . ............................. 4,25

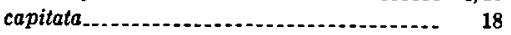
corrugata. ....................... 4, 7, 10,17, 18 lirata ovata................................ 4, 7, 13,25 pupoides........................ 25 jacksonensis......................... 5 schencki_........................ 3, 5, 8, 11, 18 sculptilis......................................... 18 sculptilis laciniata......................... 8, 11, 18

Buliminella............................ 17 subfusiformis.............. $7,9,11,17$
Page

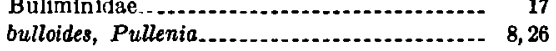

C

calcar, Robulus. .......................... 7,9,11,15 californica, Amphimorphina................- 4, 5, 25 Amphistegina............................ 3,4,22

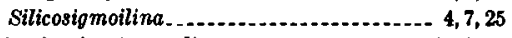
californiensis, Anomalina................. 8, 11, 13, 24 Cancris.. jocquinensis................ 4, 8, 911,22 Canoas siltstone member, Kreyenhagen shale. $\quad 6$ capitata, Bulimina Cassidulina crassipunctata...................... 8, 8, 11,12,23

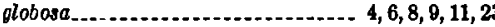
subglobosa

Cassidulinidae _.............................. 22

Cassidulinoides........................... 23 sp............................... 8, 10,11,23 celebrus, Cibicides .................... 3, 4, 8,11,24 Ceratobulimina washburni.................... 8, 26

Chilostomella oolina............................. 4, 8, 26

Chilostomellidae.............................. 23

churchi, Uvigerina............................ 4, 8, 20

Cibicides...

celebrus .

elmaensis

havdoni.............................. 8,26

hodgei

howelli_................................... 3,28

lobatus_..................... 3, 10,11,24

mcmastersi_................................. 3,26

martinezensis.............................. $\quad 4,8$

martinezensis malloryi ...................... 11, 24

venezuelanus.............................. 4,8,26

sp -............................ 3,4,8

ciervoensis, Eponides duprei.................... 8,26

Clallam formation, Foraminifera ....... 13, 16, 19, 21

stratigraphy............................

Clallam syncline . . ............................

Coaledo formation........................... 10, 21

Coast sectlon, Twin River formation..........

cocoaensis, Ellipsonodosaria............... 8, 25 Uvigerina............................. 8, 11, 12, 20

colei, Dentalina. .......................... 7,25

Tritarilina ............. 4,7,15

Collecting localitles......................... 26

colliculus, Rotobinella......................... 3,26

condoni, Gyroidina............................ 8,26

conscripta, Lagena. .................. 7,25

consobrina, Dentalina........................ 7,25

contorta, Karreriella

cooperensis, Valvulineria.................... 3,25

corrugata, Bulimina.................... 4, 7, 10, 17, 18

costata, Lagena.............................. 7, 25

costijerum, Nonion........................... 13,16

Cowlitz formation....................... 15, 21

Cozy Dell formation.......................... 18

crassifor mis, Asterigerina................. 4, 8, 10, 11, 22

crassipunctata, Cassidulina

Crescent formation, Foraminifera..... 3, 17, 18, 22, 24 paleoecology

curta, Vuloulina............................ 7,25

Cushman, J. A., quoted...................
D

Page

Deep Creek section, Twin Rlver formation ..- $\quad \theta$ deliciae, Nodasoria................. 7

Dentalina colei

consobrina............................... 7,25

dusenburyl ..................... 4, 7,25

quadrulata................................ 7,25

sp.-.-20

sp. A 1.25

sp. C.

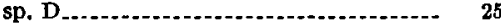

spp............. 7

depressa, Valoulineria......................... 13, 25

directa, Balivinopsis........................ 4, 7,25

Disaggregetion of samples. . . . . . . . . ............

Discocyclina (Aktinocyclina) aster............. 3

aster

psile....................................... 3,26

Discorbis alveata stapensis........................ 3,25

humilis.................................... 8, 25

duprei ciervoensis, Eponides . ................. 8,26

dusenburvi, Dentalina........................ 4, 7, 25

Eggerella sp..............................

Elkton siltstone. ............................ 17

Ellipsonodosaria cocoaensis..................... 8,25

ellisorae, Eponides.......................... 8,26

elmaensis, Cibicides............................. 4,8,26

Elphidium...................................... 16

minutum................ 7, 9, 11, 12, 13, 16 sp.......... 3

Entosolenia.................................... 19

sp. ...................... 8, 9, 11, 18

eacenica, Epistomina. ......................... 8, 26

Epistomina ecenica............................ 8,26

Epistominella parva........................... 5

Eponides.

duprei clervoensis.......................... 8,26

ellisorae...................................... 8,26

kleinpelli................................. 5

mansfieldi................................ 21

mansfieldi oreoonensis....... $8,0,11,13,21,22$

umbonatus.............................. 4, 8, 26

veoucensis........................... 4, 26

sp_........ 3

Faults..................

Faunal units, Twin River formation . . . . . . 10

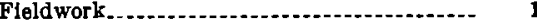

Folds

Foraminlfera, Aldwell formation....... 4

Clallam formation........................ 13

Crescent formation.

Twin River formation.................... 6

franket, Guttulina.... 7,25

frizzelli, Siphonodasaria...................... 8,25

$\mathbf{a}$

allowayi, Uvigerina garzaensis, Uvegerina................ 4, 8, 12, 20, 21 Gaudryina alazanensis................... 7, 25

sp. Govlota formation..... 


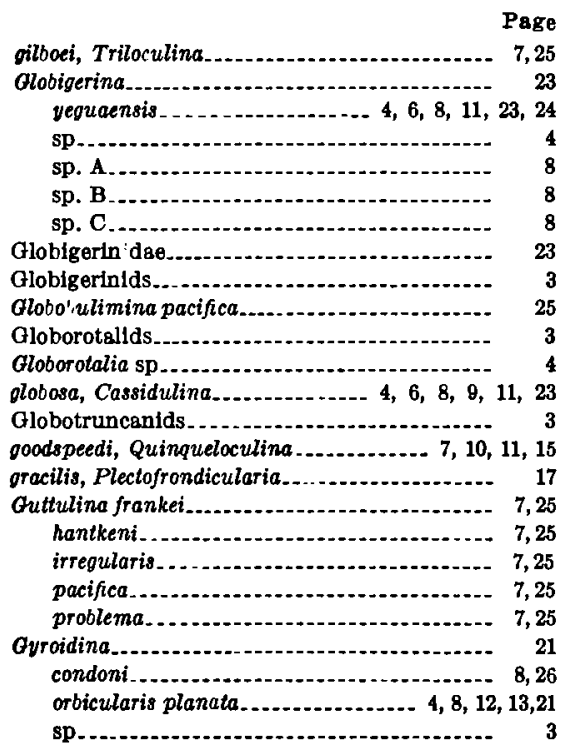

\section{H}

hamilli, Nodasaria. ..................... 7,25

hannai, Angulogerina................ 4,6,8,11,21 hantkeni, Guttulina...................... 7,25 haydoni, Cibicides............................ 8,26

Heterohellcidee hexagona scalariformis, Lagena. . ............. 25 hodgei, Cibicides............................. 4,8,26 holcombensis, Robulus..................... 4, 7,25 howelli, Cibicides_............................ 3,26 humilis, Discorbis_........................ 8,25

I

imperialis, Quinqueloculina.................. 7,25 impolata, Uvigetinella obsea.................... 25 incisa, Nonion. .............................. 16

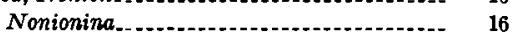
incisum, Nonion .................. 7, 9,11, 13, 16 indiscriminata, Valvulineria.................. 3,25 inflata, Pseudoglandulina................. 4, 5,7,25 irregularis, Guttulina........................ 7,25

\section{J}

jacksonensis, Bolivina. Bulimina............ 5 Valvulineria............................ 25 jacksonensis persimilis, Valoulineria........... 8,10 jenkinsi, Plectofrondicularia . ................. 5, 5,25 joaquinensis, Cancris..................... 4,8,9,11,22

\section{$\mathbf{K}$}

Karreriella contorta........... $\quad 7,25$ washingtonensis Keasey formation............................. 20, 22 kernensis, Alabamina. . . kleinpelli, Eponides...................... 5 Kreyenhagen shale.

$\mathbf{L}$

laciniata, Bulimina sculptilis _............ 8,11,18 Sculptilis........... 9

Lagena conscripta...................... $\quad 7,25$

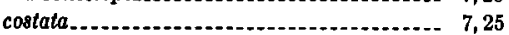
hexagona 8calariformis................... 25 sulcata.................................... 3, 7,25 suhstriala............... 7,25 Lagenida日-_.-_. latejugata, Nodosaria............. 3, 4,7,25 ligua, Pseudopolymorphina..................... 7,25 Lincoln formation ............................ 12 lirata, Bulimina............................. 4, 7,18
Lithology, Aldwell formation.

Page

Clallam formation

Crescent formation.

Lyre formation. ...

Soleduck formation.

Twin River

lobatus, Cibicides.

$3,8,10,11,24$

1

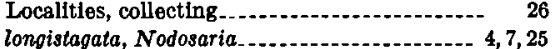

Loxostomum applini

Lyre formation, paleoecology stratigraphy ............... 2

Lyre Rlver section, Twin River formation.... 6

3,26

Mabury Reef sandstone, correlated with Crescent formation...... 4

macrostoma, Allomorphina

malloryi, Cibzcides martinezensis............. 11, 24

mansfieldi, Eponides.............................. 21

mansfieldi oregonensis, Epónides....- 8, $9,11,13,21,22$

marginata adelaidana, Bolivina............ 8,9,11,19

Marginulina subbullata................. 4, 7,25

martinezensis, Cibicides..................... 4,8

martinezensis malloryi, Cibicides............... 11,24

menloensis, Valoulineria................. 8, 25

Millolidae.

minutum, Elphidium................ 7,9,11,12, 13,16

multilineata, Plectofrondicularia packardi _ . 4, 7, 16,17

\section{N}

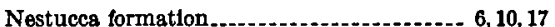

Nodogenerina adolphina......................... 25

Nodosaria anomala........................... 7,25

deliciae................................ 7

hamilli................................ 7,25

latejugata............ 3, 4, 7, 25

longistagata............ 4, 7,25

Nonion 16

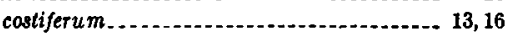
incisa incusum.......................... 7,9,11,13, 16 pompilioides...................... 7,9,12,16, 24

Nonionella boueane............................ 16

Nonlonidae................... 16

Nonionina incisa.............................. 16

Nummoloculina sp............. 7

nuttalli, Bifarina......... 4,19

Nye mudstone . . . . . . . . . .............. 13, 19, 22, 23

0

obsea impolata, Uvigerinella.............. 25 oolina, Chilostomella........................ 4,8,26 orbicularis planata, Gyroidina..........- 4,8,12,13,21 oregonensis, Eponides mansfieldi..... 8,9,11,13, 21, 22 ovata, Bulimina......................... 4, 7, 13,25 $\mathbf{P}$

pacifica, Globobulimina Guttulina................................. 7,25 packardi, Anomalina..................... 3,26 Plectofrondicularia........ 17 Plectofrondicularia packardi............. 7,11,17 packardi multilineata, Plectofrondicularia. _ 4, 7,16, 17 packardi packardi, Plectofrondicularia........ 7,11,17 Paleoecology, Aldwell formation.............. 6,14 Clallam formation...................... 13 Crescent formation........................ 13 Interpretations based on Foraminifera.... 13 Lyre formation. ........................ 14

Twin River formation..................... 12,14 parva, Epistominella................ 5 persimilis, Valoulineria jacksonensis............ 8,10 planata, Gyroidina orbicularis .......... 4,8,12,13;21

Planktonic assemblages, Crescent formation.-

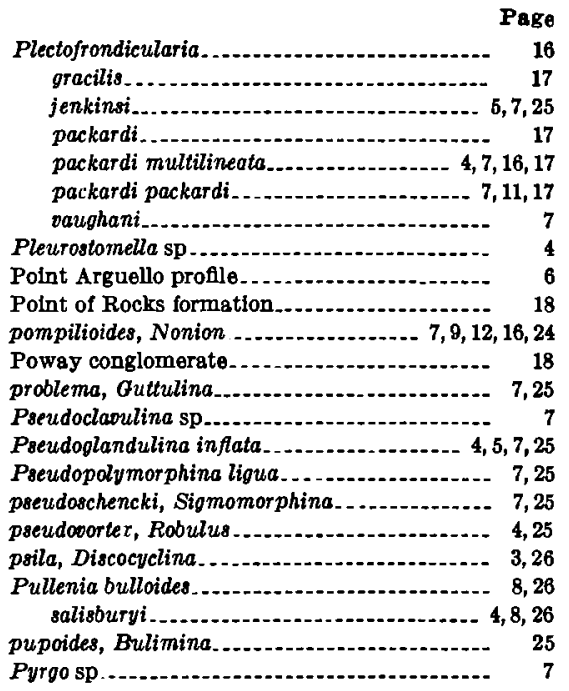

quadrulata, Dentalina.

Quinqueloculina.

goodspeedi............................ 7, 10,11,15

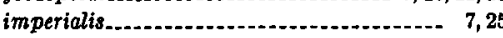

triangularis............................. 7,25

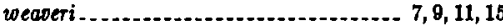

sp.

regina, Anomalina. Regional correlation, Twin River formation.. 10 Robulus calcar. hoicombensis ............................ 4, 7,25 pseudovorted ... . . .

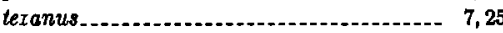
welchi. . . ............................. 4, 7, 10,15 sp. spp Rotalldae....................... 21 Rotobinella colliculus.

salisburvi, Pullenia........................ 4,8,26 San Lorenzo formation. . . ...................... 12, 23 scalariformis, Lagena hexagona...........- 25 schencki, Bulimina........................ 3, 5,8,11, 18

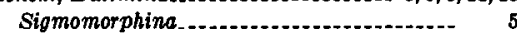
sculptilis, Bulimina............................. 18 sculptilis laciniata, Bulimina........... 8, $9,11,18$ Slerra Blanca limestone, correlated with Crescent formation..............

Sigmoilina tenuis Sigmomorphina pseudoschencki..........-... 7,25 schencki............. Silicosigmoilina californica...................... 4, 7, 25 Siphonodosaria frizzelli................. 8,25 Skookumchuk formation ................. 15 Soleduck formation, stratigraphy ............. 1 structure. Sphaeroidina..................... 23

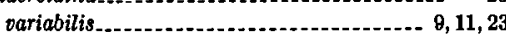
Spiroloculina texanus....................... 7,25 Spiroplectamina sp........... 7 stavensis, Discorbis alveata.................... 3,25 Stratigraphy.................................

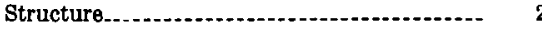
subbullata, Marginulina_........-.......-.- 4,7,25 subfusiformis, Buliminella................. 7,9,11,17 subglobosa, Cassiduliria........................ 8 substriata, Lagena.......................... 7,25 sulcata, Lagena. .............................. 3, 7, 25

Synonymy . . . . .............................. 15 
Tejon formation...........................

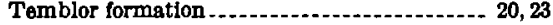

teninoensis, Baggina. . . . . ................ 8,26

tenuis, Sigmoilina...

texanus, Robulus .-1

Spiroloculina . .

Toledo formation................... 6,10,12,17,19,22

triangularis, Quinqueloculina.............. 7,25

Triloculina gilboei............................... 7,25

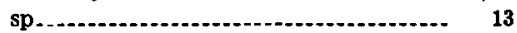

Tritaxilina. .

colei.................................... 4, 7,15

sp.............. 3

Tumey formation

tumeyensis, Valoulineria. .................... 4,8,25

Twin River formation, Foraminifers ......... 6,15

$17,18,19,20,21,22,23,24$

paleoecology

stratigraphy

U

umbonatus, Eponides.

$4,8,26$

Umpqua formation................ 17, 18, 19, 22, 24
Uoigerina

$4,8,20$

cacoaensis............................ 8,11,12,20

gallowayi. . . . .

garzaensis......... 4,8,12,20,21

Uvigerinella obsea impolata............-...... 25

v

vacavillensis, Vaginulinopsis_................ 4,5,25

Vaginulinopsis pacavillensis................. 4, 5, 25

Valvulineria cooperensis

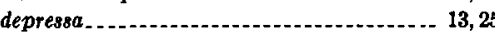

indiscriminata .......... 3,25

jacksonensis.

jacksonensis persimilis..................... 8,10

menloensis

tumeyensis............................... 4, 8, 25

willapaensis....................... 8,26

sp-_.........

Valvulinidae

Vaqueros formation . . ................. 20, 23
Page

variabilis, Sphaeroidina................... 8,9,11,23

Vaughan, T. W., quoted.................

vaughani, Plectofrondicularia

venezuelanus, Cibicides........................ 4, 8,26

Verdun formation

Viroulino Sp-

Volcanism........................................... 3

Vulvulina curta............... 7,25

Sp.

7

Wagonwheel formation................ 12, 20, 22

uashburni, Ceratobulimina................... 8,26

washingtonensis, Karreriella................ 7,25

weaveri, Quinqueloculina................... 7,9,11,15

welchi, Robulus,

willapaensis, Valvulineria................ 8,26

Yamhill formation......................... 6,17

Yaquina formation.

yazooensis, Uoigerina..................... 5,20

veouaensis, Eponides

Globigerina. ................ 4, 6, 8, 11, 23, 24 

PLATES 5-7 


\section{PLATE 5}

\section{[All figures $\times 60]$}

FIGdRE 1. Quinqueloculina goodspeedi Hanna and Hanna (p. G15). USNM 626982. USGS f11874, Twin River formation. a, Side view; b, opposite side view; c, apertural view.

2. Tritaxilina colei Cushman and Siegfus (p. G15). USNM 626981. USGS f11884, Twin River formation.

3. Quinqueloculina weaveri Rau (p. G15). USNM 626983. USGS f11793, Twin River formation. a, Side view; b, opposite side view; c, apertural view.

4. Robulus cf. R. calcar (Linné) (p. G15). USNM 626984. USGS f11754, Twin River formation. a, Side view; b, peripheral view.

5. Nonion costiferum (Cushman) (p. G16). USNM 626986. USGS f11891, Clallam formation. a, Side view; b, peripheral view.

6. Robulus welchi Church (p. G15). USNM 626985. USGS f11726, Aldwell formation. a, Side view; b, peripheral view.

7. Nonion cf. $N$. pompilioides (Fichtel and Moll) (p. G16). USNM 626988. USGS f11749, Twin River formation. a, Side view; b, peripheral view.

8. Elphidium cf. E. minutum (Reuss) (p. G16). USNM 626989. USGS f11891, Clallam formation. a, Side view; b, peripheral view.

9. Nonion incisum (Cushman) (p. G16).

USNM 626987. USGS f11731, Twin River formation. a, Side view; b, peripheral view.

10. Bulimina schencki Beck (p. G18). USNM 626997. USGS f11875, Twin River formation.

11. Bulimina corrugata Cushman and Siegfus (p. G17). USNM 626993. USGS f11886, Twin River formation. a, Side view; b, apertural view.

12. Buliminella subfusiformis Cushman (p. G17). USNM 626992. USGS f11867, Twin River formation.

13. Plectofrondicularia packardi packardi Cushman and Schenck (p. G17). USNM 626991. USGS f11876, Twin River formation.

14. Bulimina cf. B. alsatica Cushman and Parker (p. G18). USNM 626996. USGS f11815, Twin River formation. a, Side view; $b$, apertural view.

15. Plectofrondicularia packardi multilineata Cushman and Simonson (p. G16). USNM 626990. USGS f11736, Twin River formation.

16. Bulimina alsatica Cushman and Parker (p. G18). USN M 626995. USGS f11749, Twin River formation. a, Side view; b, apertural view.

17. Bulimina lirata Cushman and Parker (p. G18).

USNM 626994. USGS f11873, Twin River formation. a, Side view; b, apertural view. 
GEOLOGICAL SURVEY
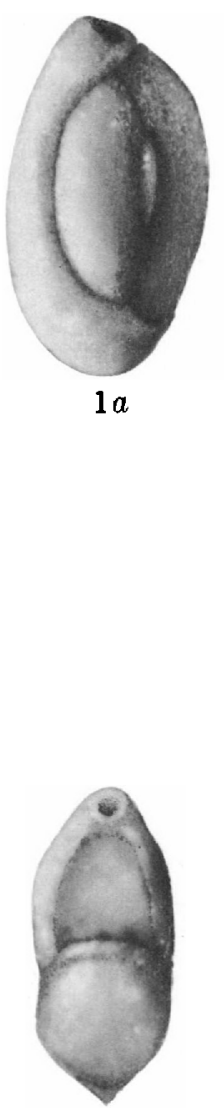

$4 b$

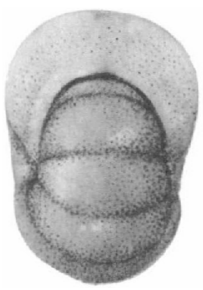

76
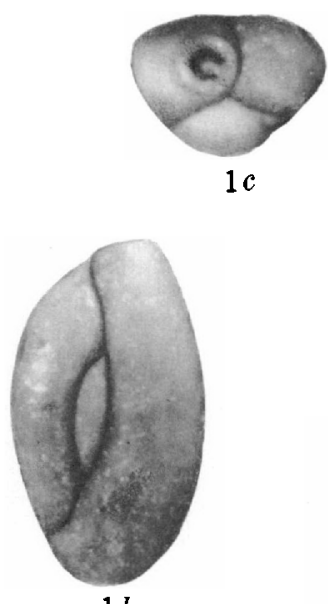

$1 b$
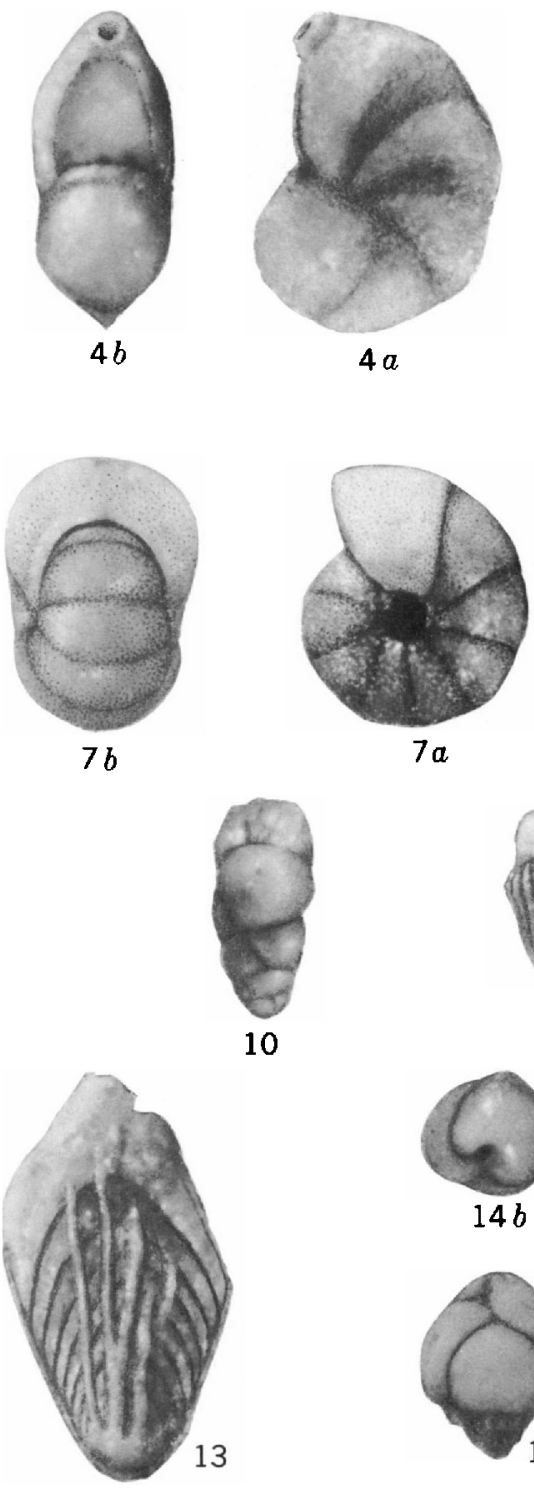
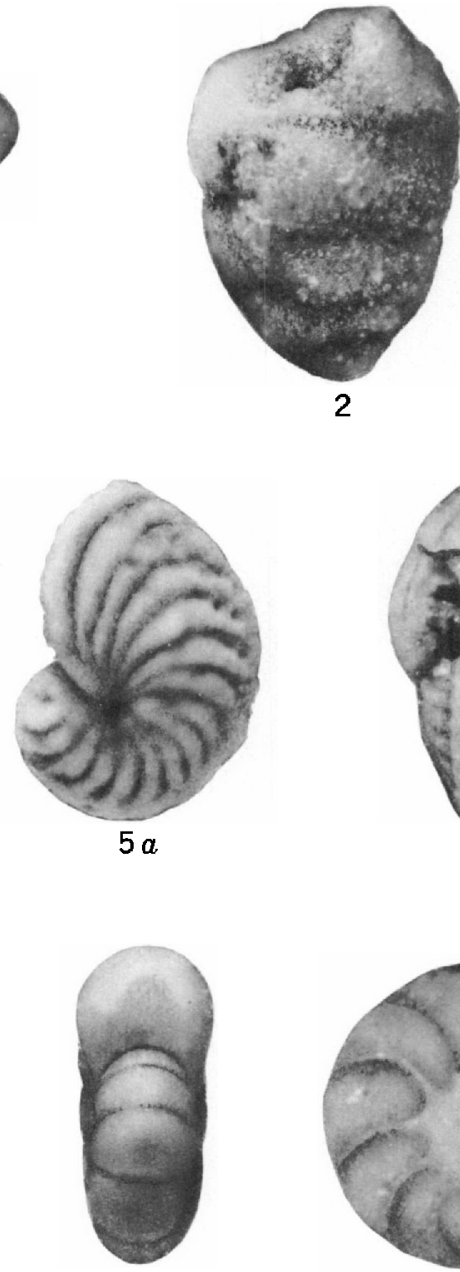

$8 b$
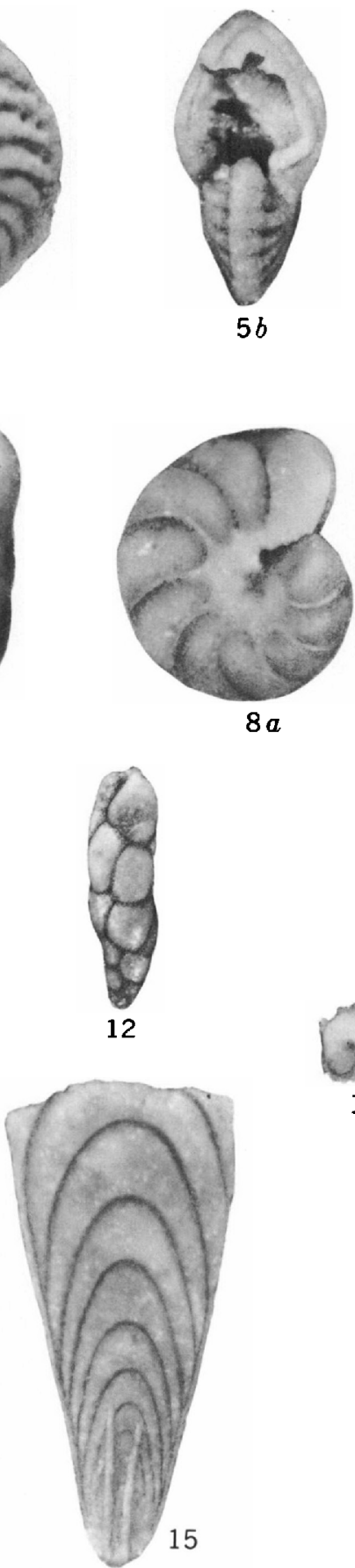

PROFESSIONAL PAPER 374-G PLATE 5
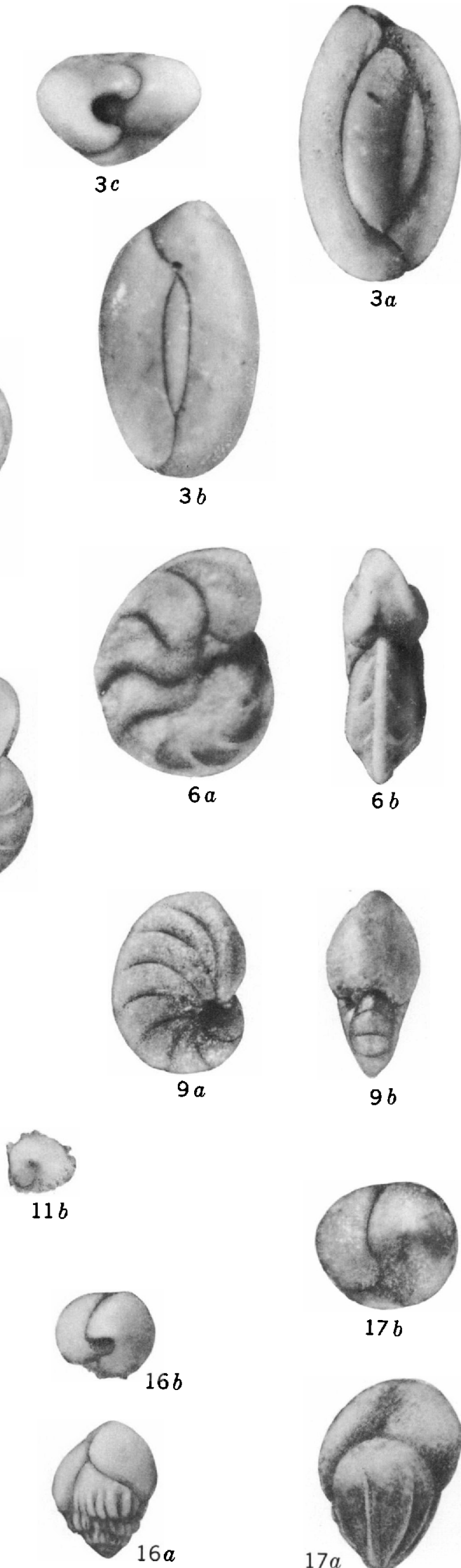

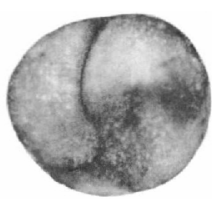

$17 b$

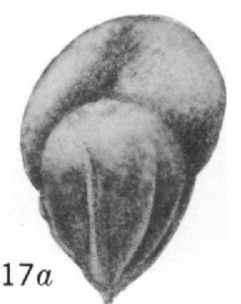




\section{PLATE 6}

[All flgures $\times 60$ ]

Figdre 1. Bulimina sculptilis laciniata Cushman and Parker (p. G18). USNM 626998. USGS f11865, Twin River formation. a, Side view; b, apertural view.

2. Entosolenia sp. (p. G19). USNM 626999. USGS f11751, Twin River formation. a, Side view; b, apertural view.

3. Bifarina nuttalli Cushman and Siegfus (p. G19). USNM 627002. USGS f11728, Aldwell formation.

4. Bolivina advena Cushman (p. G19). USNM 627000. USGS f11749, Twin River formation.

5. Uvigerina cocoaensis Cushman (p. G20). USNM 627004. USGS f11862, Twin River formation. a, Side view; b, apertural view.

6. Uvigerina garzaensis Cushman and Siegfus (p. G20). USNM 627006. USGS f11748, Twin River formation. a, Side view; b, apertural view.

7. Uvigerina gallowayi Cushman (p. G20). USNM 627005. USGS f11748, Twin River formation. a, Side view; b, apertural view.

8. Bolivina marginata adelaidana Cushman and Kleinpell (p. G19). USNM 627001. USGS f11869, Twin River formation.

9. Uvigerina churchi Cushman and Siegfus (p. G20). USNM 627003. USGS f11728, Aldwell formation.

10. Gyroidina orbicularis planata Cushman (p. G21). USNM 627008. USGS f11749, Twin River formation. a, ventral view; $b$, dorsal view; $c$, peripheral view.

11. Angulogerina hannai Beck (p. G21). USNM 627007. USGS f11886, Twin River formation.

12. Eponides mansfieldi oregonensis Cushman, Stewart and Stewart (p. G21). USNM 627009. USGS f11791, Twin River formation. a, ventral view; b, dorsal view; c, peripheral view.

13. Cancris joaquinensis Smith (p. G22). USNM 627010. USGS f11862, Twin River formation. a, ventral view; b, dorsal view; c, peripheral view.

14. Asterigerina crassiformis Cushman and Siegfus (p. G22).

USNM 627011. USGS f11726, Aldwell formation. a, ventral view; b, dorsal view; $c$, peripheral view. 


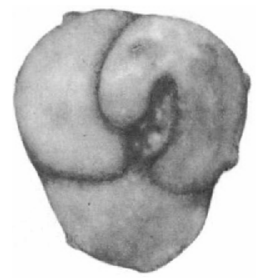

$1 b$
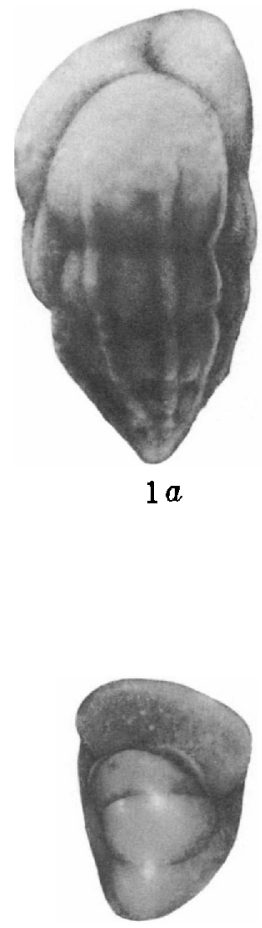

$10 c$
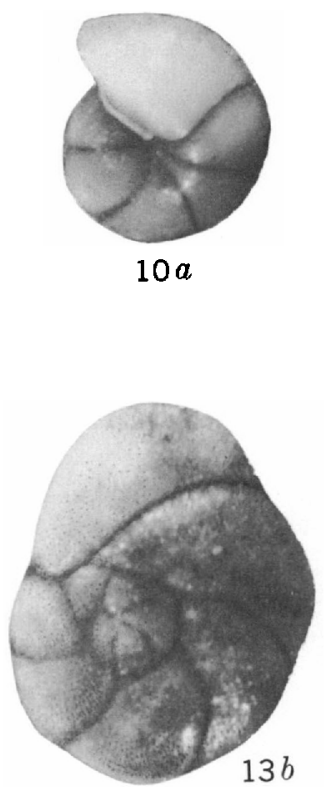
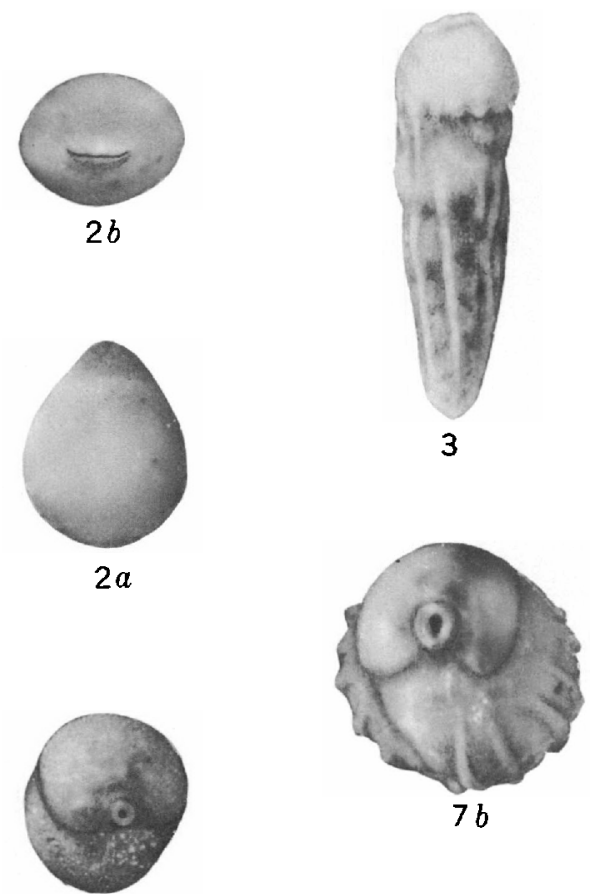

$6 b$
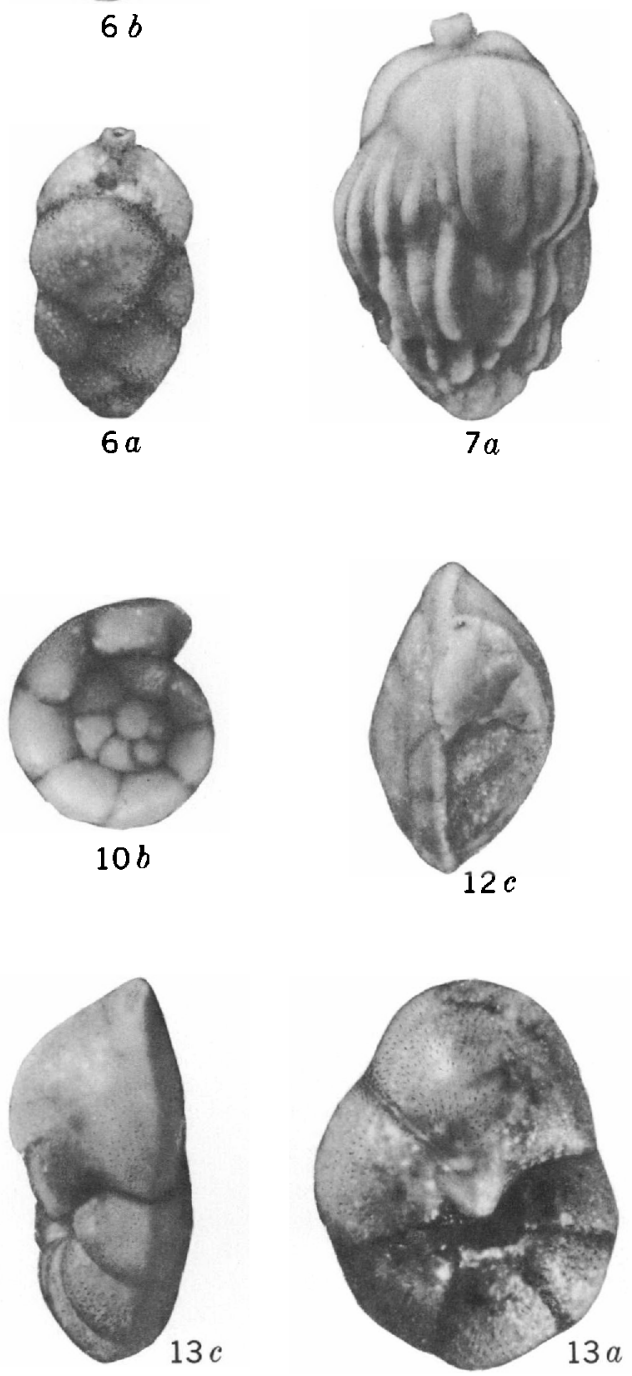
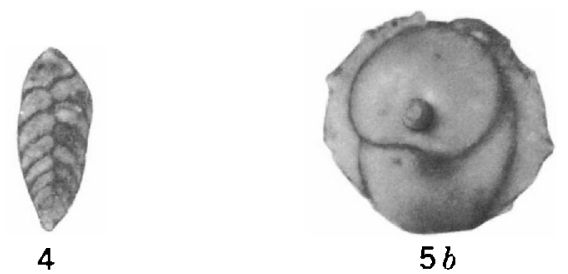

$5 b$
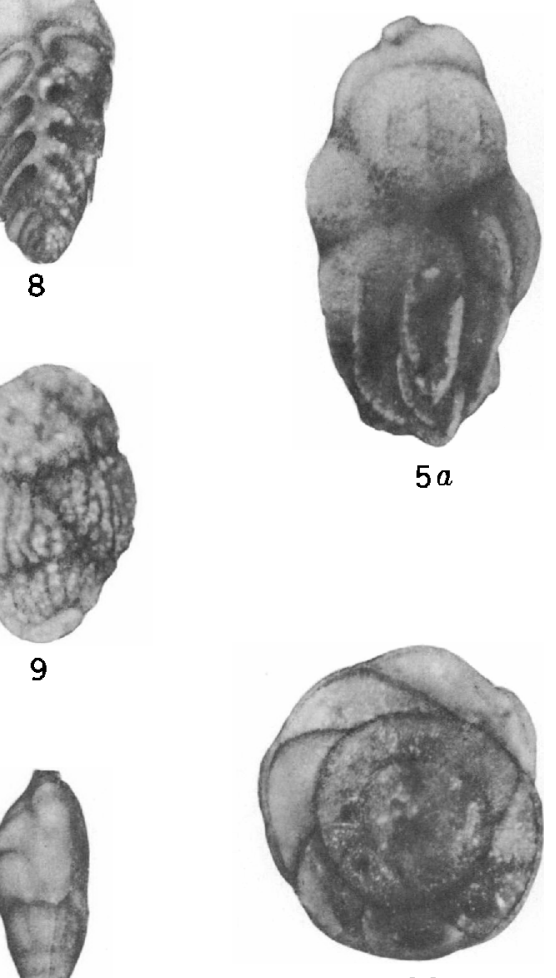

$12 b$

11

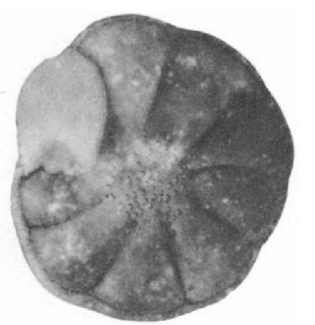

$12 a$
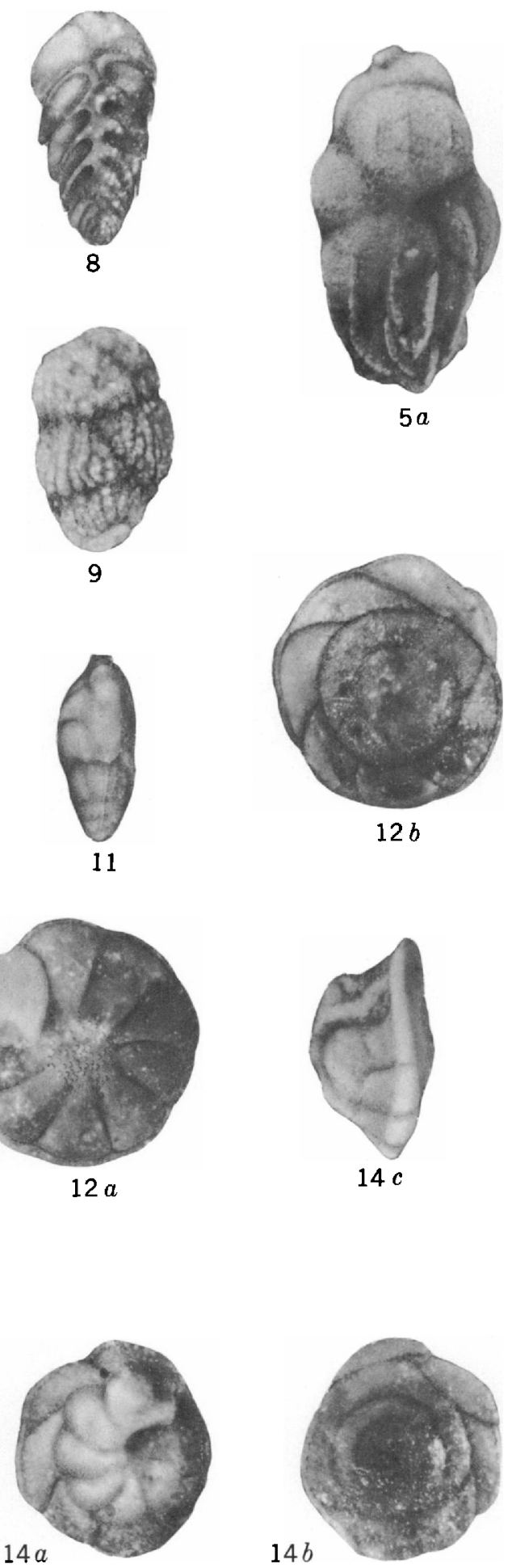


\section{PLATE 7}

[All figures $\times 60$ except 12 and $13, \times 20$ ]

Figdre 1. Alabamina kernensis Smith (p. G22).

USNM 627013. USGS $f 11862$, Twin River formation. a, ventral view; $b$, dorsal view; $c$, peripheral view.

2. Cassidulinoides sp. (p. G23).

USNM 627016. USGS f11869, Twin River formation.

3. Cassidulina crassipunctata Cushman and Hobson (p. G23).

USNM 627014. USGS f11796, Twin River formation. a, Side view; b, peripheral view.

4. Cassidulina globosa Hantken (p. G23).

USNM 627015. USGS f11843, Twin River formation. a, Side view; b, apertural view.

5. Globegerina cf. G. yeguaensis Weinzierl and Applin (p. G23).

USNM 627018. USGS f11729, Aldwell formation.

6. Amphistegina californica Cushman and M. A. Hanna (p.G22).

USNM 627012. USGS f11720, Crescent formation.

7. Sphaeroidina variabilis Reuss (p. G23).

USNM 627017. USGS f11815, Twin River formation. a, Side view; b, apertural view.

8. Anomalina californiensis Cushman and Hobson (p. G24).

USNM 627019. USGS f11876, Twin River formation. a, Side view; b, peripheral view.

9. Cibicides lobatus (d'Orbigny) (p. G24).

USNM 627021. USGS f1 1882, Twin River formation. a, ventral view; b, dorsal view; c, peripheral view.

10. Cibicides celebrus Bandy (p. G24).

USNM 627020. USGS f11874, Twin River formation. a, ventral view; b, dorsal view; $c$, peripheral view.

11. Cibicides martinezensis malloryi Smith (p. G24).

USN M 627022. USGS f11799, Twin River formation. a, ventral view, b, dorsal view; c, peripheral view.

12, 13. Thin section of reddish arglllaceous limestone from the Crescent formation showing globorotalids and globigerinids. USNM 627023. USGS f11714. 
GEOLOGICAL SURVEY

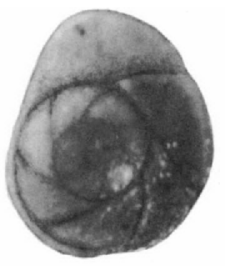

$1 b$

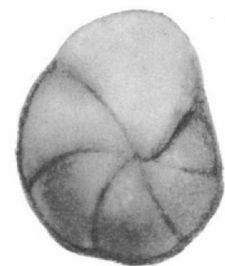

$1 a$

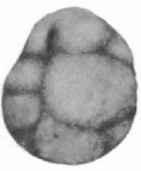

$4 a$

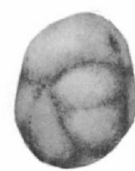

$4 b$
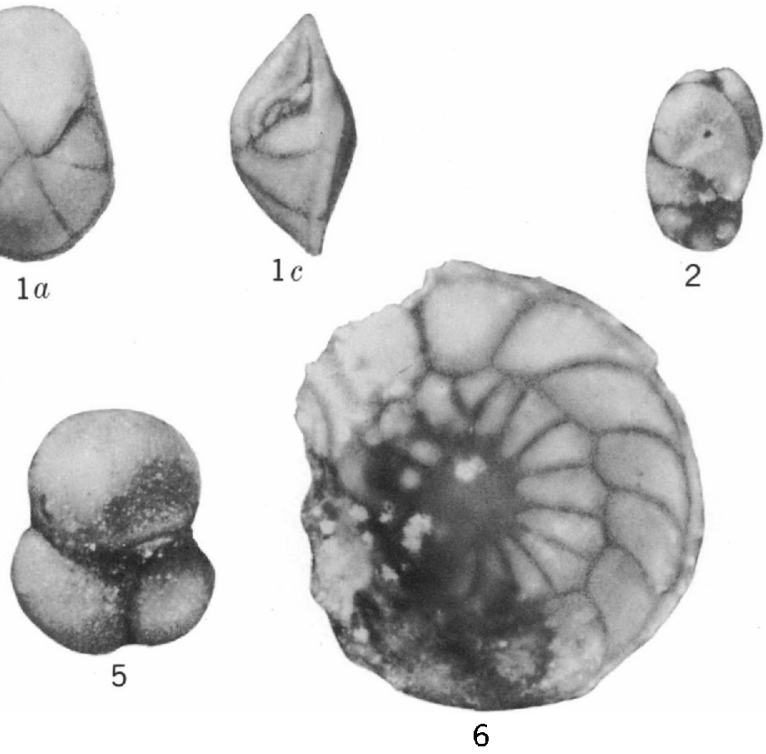

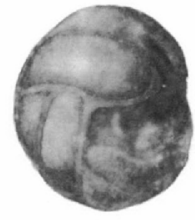

$3 a$

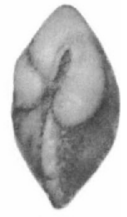

$3 b$
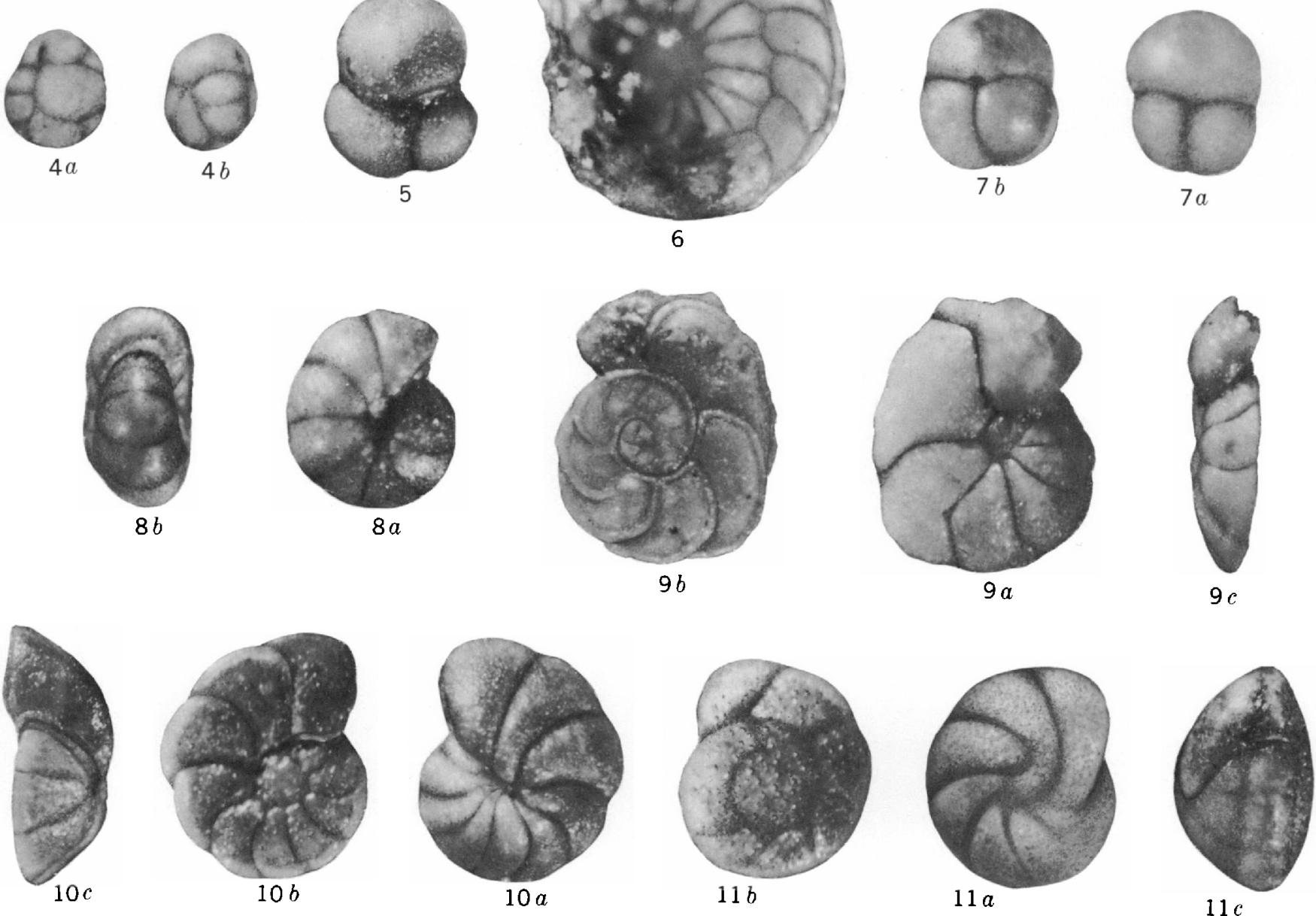

12

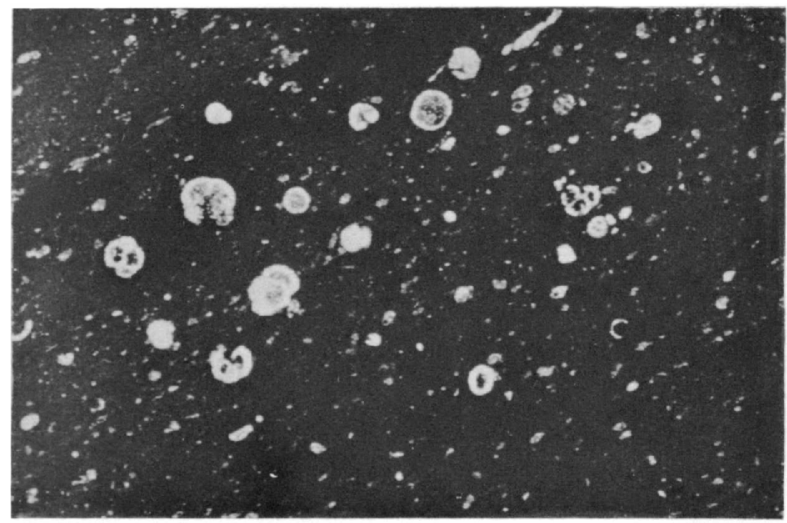

13

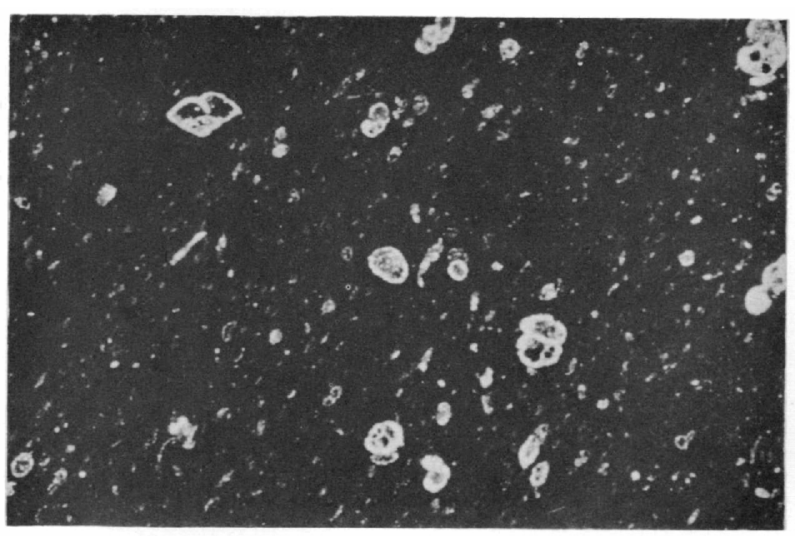





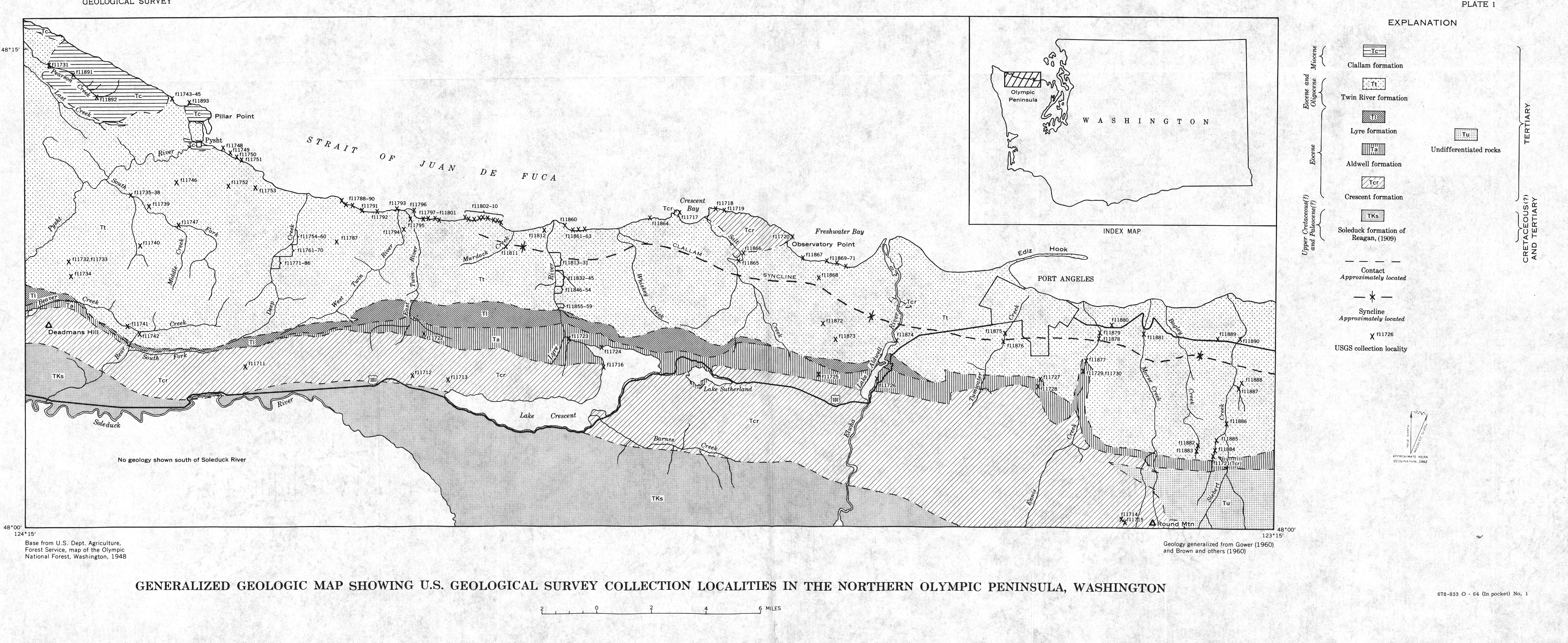




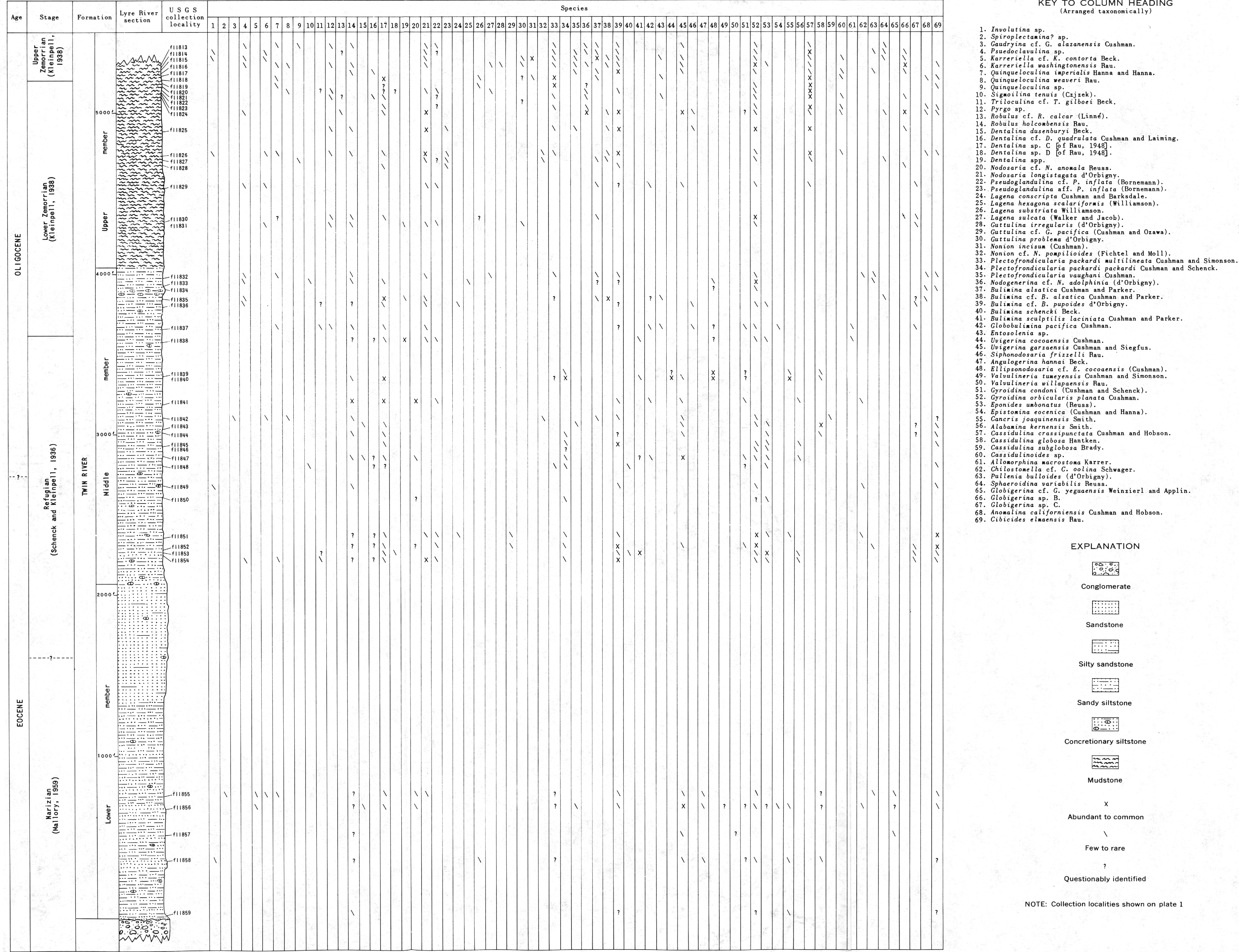





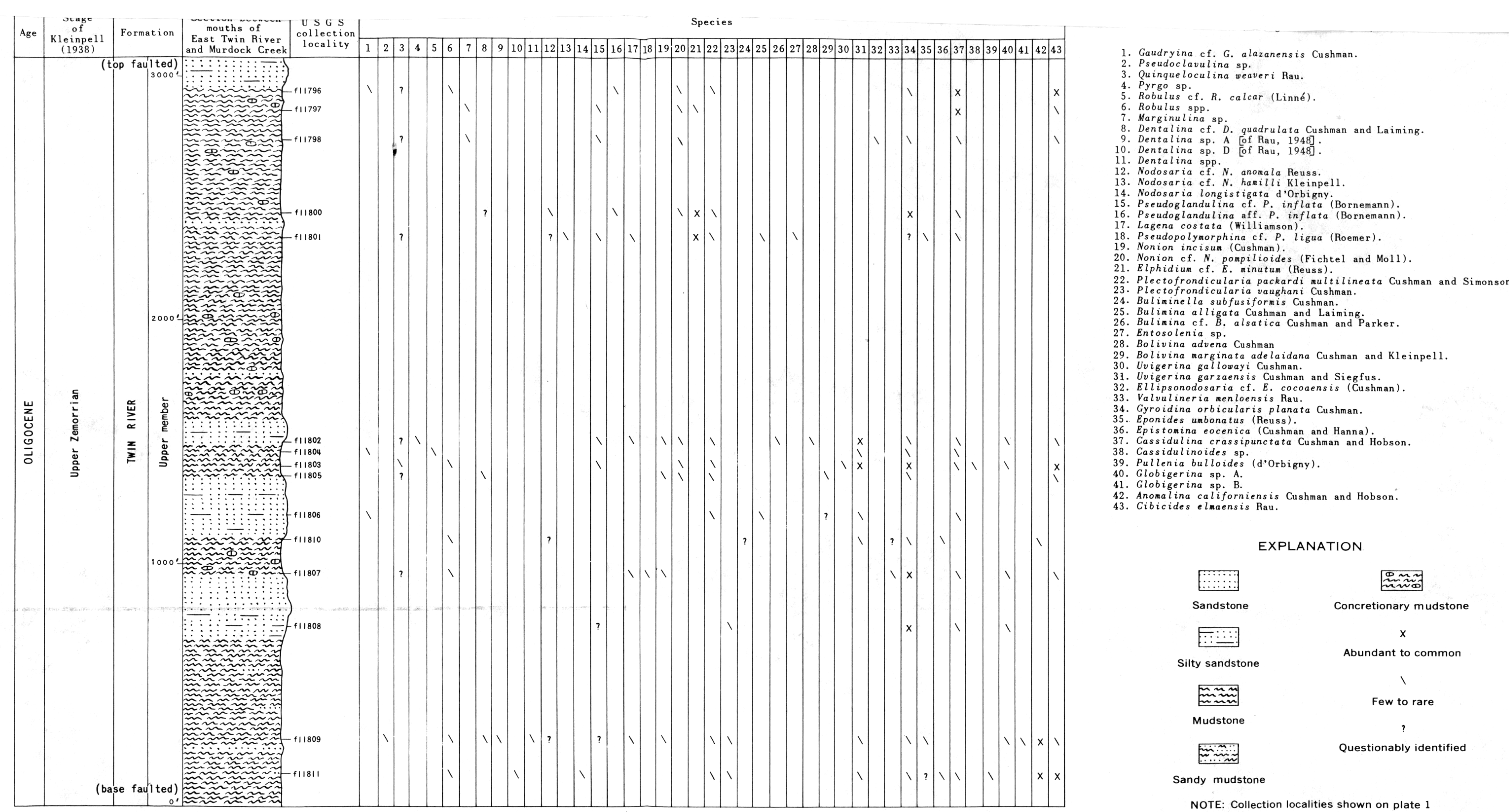

FORAMINIFERA FROM A PART OF THE TWIN RIVER FORMATION BETWEEN THE MOUTHS OF EAST TWIN RIVER AND MURDOCK CREEK IN THE NORTHERN OLYMPIC PENINSULA, WASHINGTON 
